\title{
A PRELIMINARY INVESTIGATION OF THE HYDROGEOLOGY
}

AND CONTAMINATION IN THE AREA OF AN

ABANDONED MANUFACTURED GAS PLANT

IN ALBANY, GEORGIA

By M.J. Chapman, B.M. Gallaher, and D.A. Early

\section{U.S. GEOLOGICAL SURVEY}

Water-Resources Investigations Report 90-4141

Prepared in cooperation with

CITY OF ALBANY

WATER, GAS, AND LIGHT COMMISSION

Doraville, Georgia 


\section{U.S. DEPARTMENT OF THE INTERIOR \\ MANUEL LUJAN, JR., Secretary}

U.S. GEOLOGICAL SURVEY

Dallas L. Peck, Director

For additional information write to:

District Chief

U.S. Geological Survey

6481 Peachtree Industrial Blvd.

Suite $B$

Doraville, GA 30360
Copies of this report can be purchased from:

U.S. Geological Survey Books and Open-File Reports Federal Center, Bldg. 810 Box 25425

Denver, CO 80225 


\section{CONTENTS}

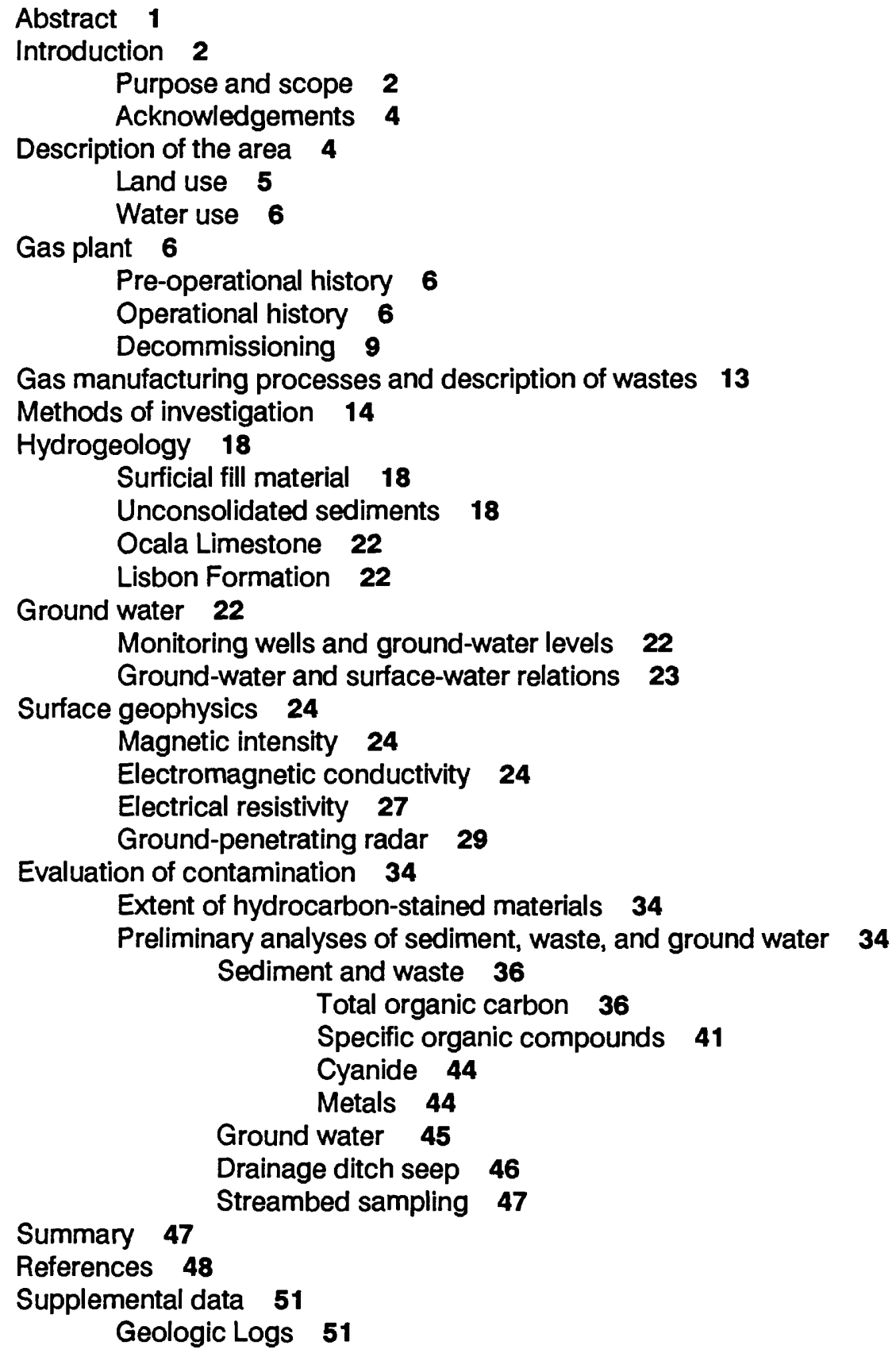




\section{ILLUSTRATIONS}

Figures 1-2. Maps showing:

1. Location of the study area, ice plant, gas plant, and former landfill in the Albany area 3

Figures 3-9. Photographs showing:

3. Graded landfill south of the Albany gas plant, April 17, 19597

4. Flooding of the Flint River at the Albany gas plant, January 19258

5. Flooding of the Flint River and the presence of numerous barrels at the Albany gas plant 9

6. Presence of numerous tanks at the former Albany gas plant, 195310

7. The metal framework of the largest tank (tank A, fig. 2) at the former gas plant, April 17, 195911

8. A large, open pool of hydrocarbon liquid at the former gas plant after the removal of the largest tank (tank A, fig. 2), January 12, 196212

Figure 9. Locations of geologic sections, fence diagram, auger borings, test pits (trenches), wells, and geophysical data stations in part of the study area 16

10. Generalized schematic fence diagram showing lithology of an area adjacent to the abandoned gas plant 19

Figure 11. Map showing altitude of the top of the upper clay layer and general directions of ground-water flow in the upper sand layer 20

Figure 12. Graph showing comparison of the Daily mean water level in well HS-1 and stage of the Flint River, April-July, 198921

Figures 13-16. Maps showing:

13. Altitude of the top of the Ocala Limestone 23

14. Results of a magnetometer survey showing a negative anomaly centered over a buried tank 25

15. Apparent conductivity survey; 20 -meter horizontal coils 26

16. Locations of resistivity sounding surveys 28

Figure 17. Schematic showing two of five possible electrode configurations used in the offset Wenner resistivity sounding technique 29

18. Graphs showing apparent resistivity sounding curves:

18a. VES-1 30

18b. VES-2 30

18c. VES-3 30

18d. VES-4 30

18e. VES-5 30

19. Map showing ground-penetrating radar survey lines and outline of the area of low radar reflection 31

20. Schematic showing radar section along line L3 (D-D') showing sharp breaks in the depths of reflection 32

21. Schematic showing radar section along line $L 3.5$ (E-E') showing strong "echoes" in the vicinity of known iron pipes 33

Figures 22-24. Geologic sections showing the distribution of total organic carbon at:

22. Wells HS-9, HS-1, and HS-10 37

23. Well HS-12, boring HS-8, and well HS-11 38

24. Boring HS-8, well HS-2, and well HS-1 39 


\section{TABLES}

Table 1. Inventory of borings and trenches in the unconsolidated sediments in the study area 15

2. Inventory of wells in the unconsolidated sediments in the study area 17

3. Volatile-phase hydrocarbons detected in boreholes during drilling operations 35

4. Total organic carbon concentrations in sediments $\mathbf{4 0}$

5. Volatile and semivolatile organic-compound concentrations detected in a liquid hydrocarbon-waste sample from well B-5, April 21, 198942

6. Volatile organic-compound concentrations in sediment cores 43

7. Cyanide concentrations in sediment cores 44

8. Metal concentrations in sediment samples 45

9. Semivolatile organic-compound concentrations detected in ground water from well HS-1, April 21, 198946

10. Volatile organic-compound concentrations in seep, June 1, 198946 


\section{CONVERSION FACTORS}

For use of readers who prefer to use metric (International System) units, conversion factors for terms used in this report are listed below:

\section{Multiply inch-pound units}

by

\section{Length}

inch (in.)

foot (ft)

mile (mi)

acre

cubic foot $\left(\mathrm{ft}^{3}\right)$

25.4

1.609

Area

\section{Volume}

gallon (gal)

0.3048

0.4047

$3.785 \times 10^{-3}$

0.02832

Flow

cubic foot per second $\left(\mathrm{ft}^{3} / \mathrm{s}\right)$

ounce (oz)

pound (Ib)
0.02832

\section{Mass}

0.4536
$2.835 \times 10^{-2}$

\section{to obtain metric units}

millimeter $(\mathrm{mm})$

meter $(m)$

kilometer $(\mathrm{km})$

hectare

liter (L)

cubic meter $\left(\mathrm{m}^{3}\right)$ cubic meter per second $\left(\mathrm{m}^{3} / \mathrm{s}\right)$

kilogram $(\mathrm{kg})$

killogram $(\mathrm{kg})$

Sea level--In this report "sea level" refers to the National Geodetic Vertical Datum of 1929 (NGVD of 1929)--a geodetic datum derived from a general adjustment of the first-order level nets of both the United States and Canada, formerly called "Sea Level Datum of 1929." 


\title{
A PRELIMINARY INVESTIGATION OF THE HYDROGEOLOGY
}

\author{
AND CONTAMINATION IN THE AREA OF AN ABANDONED \\ MANUFACTURED GAS PLANT IN ALBANY, GEORGIA
}

\author{
By M.J. Chapman, B.M. Gallaher, and D.A. Early
}

\begin{abstract}
Prior to the introduction of natural gas pipelines in the 1950's, gas for lighting and heating in the United States was produced from coal or oil, or a combination of both, at local manufactured gas plants. By-products and wastes generated at these plants commonly were disposed of on site. The major wastes, which include tar and oil residues and sludges, spent oxides, and ash materials, also can include a complex mixture of hundreds of aromatic organic compounds as well as cyanides and metals. The U.S. Environmental Protection Agency lists many of these constituents as carcinogenic or priority pollutants, or both. An investigation was initiated in January 1989 in the vicinity of an abandoned manufactured gas plant in Albany, Georgia, to evaluate the extent and movement of these contaminants in hydrogeologic systems such as those present in the area.
\end{abstract}

Geologic formations of interest to this investigation are, in descending order, unconsolidated sediments consisting of sand and clay layers, the Ocala Limestone, and the Lisbon Formation. Surficial fill (man-made) overlies the sand and ciay layers throughout the study area. The thickness of the fill ranges from about 2 to 10 feet, and the depth to the Ocala Limestone ranges from about 14.0 to 30.5 feet. Locally, two sand layers that are seasonally saturated are present in the unconsolidated sediments in the study area: a shallow, upper sand layer, which generally is less than 10 feet below land surface; and a deeper, lower sand layer that is in contact with the Ocala Limestone. The upper sand layer receives recharge from the direct infiltration of rainfall or ponded water through the fill material. The ground-water level in the lower sand layer is influenced by changes in the stage of the nearby Flint River. A clay confining layer that ranges in thickness from 0.5 to 6.5 feet separates the two sand layers. Ground water in the upper sand layer is perched above the clay confining layer.

A total of 33 borings were drilled into the unconsolidated sediments to depths ranging from 1.5 to 30.5 feet. Sediment and waste samples were collected during drilling and chemically analyzed for specific organic compounds, metals, cyanide, and total organic carbon. Polyvinylchloride well casings were installed in $\mathbf{1 0}$ of the boreholes to facilitate the measurement of water levels and to allow the collection of ground-water samples in the upper and lower sand layers. Most wells were dry during the study period, except two wells tapping the lower sand layer; a water-level recorder was installed on one of these wells.

High concentrations of hydrocarbons and various metals, and cyanide were detected in sediment and ground-water samples collected in the vicinity of the former gas holding tanks. Maximum concentrations of hydrocarbons detected included 560,000 micrograms per kilogram naphthalene, 73,000 micrograms per kilogram ethylbenzene, 28,000 micrograms per kilogram benzene, and 24,000 micrograms per kilogram toluene. Hydrocarbon concentrations in a liquid tank sludge sample included 18,000 micrograms per liter naphthalene, 17,000 micrograms per liter benzene, and 5,300 micrograms per liter phenanthrene. Four phases of hydrocarbons were present in this area--solid, fluid, aqueous, and volatile phases. These hydrocarbons are present at least to the depth of the contact between the unconsolidated sand and clay sediments and the Ocala Limestone in this area. The concentration of hydrocarbons decreased with increasing areal distance away from the gas holding tanks. Ground-water and unconsolidated sediment samples that were collected 150 to 200 feet east of the area near the former gas holding tanks contained only a few hydrocarbon compounds in relatively low concentrations. 


\section{INTRODUCTION}

From as early as 1816 and into the 1960's, gas for lighting and heating in the United States was produced from coal or oil, or a combination of both, at manufactured gas plants. Prior to World War il, there were more than 1,000 such piants throughout the United States (Edison Eiectric institute, 1984). Following the introduction of interstate pipeines for natural gas distribution in the late 1940's and eariy 1950 's, manufactured gas plants began to cease operations because of the lower heating value of manufactured gas (measured in British Thermai Units) compared to that of the less expensive naturai gas.

Gas piant by-products and wastes commoniy were disposed of on site and may stiii be present in the environment. These primary wastes inciude condensed tar residues and sludges, spent oxides, and ash materiais. These wastes also may inciude a complex mixture of hundreds of aromatic organic compounds, as weil as cyanides and metals, many of which are recognized by the U.S. Environmental Protection Agency (EPA) $(1986,1989)$ as carcinogenic or priority poilutants, or both.

Although it has been decades since manufactured gas piants ceased operations, the presence of their generated wastes in the environment and the possibie migration of waste constituents into surface- or ground-water supplies have resuited in concern about public health and environmental contamination. Despite the widespread distribution of gas piants and the potentialiy harmful nature of the associated wastes, few of these sites have been investigated.

In January 1989, the U.S. Geoiogicai Survey (USGS), in cooperation with the Aibany Water, Gas, and Light Commission (AWGLC), began a study in the vicinity of an abandoned manufactured gas plant in Aibany, Ga. (fig. 1). Resuits of this study can be used to guide management and remediation decisions reiated to this and other abandoned manufactured gas piants in similar hydrogeoiogic environments.

\section{Purpose and Scope}

This study is composed of two separate phases. This report documents the resuits of Phase I, which was designed to (1) deiineate and describe the hydrogeoiogic framework of the unconsolidated sediments, piant-site debris, and fili materiai; (2) chemicaily characterize the wastes at the abandoned gas piant, and conduct a preiiminary evaiuation of the distribution of seiected contaminants In the unconsolidated sediments and fiil; and (3) provide a preiiminary anaiysis of potential pathways of contaminant migration. The pianned second phase of the investigation wili better define the hydrogeoiogy and extent of contamination in the unconsolidated sediments and wili inciude an evaiuation of the underiying aquifer.

The scope of Phase $\mathrm{i}$ inciuded (1) revlewing historical information on the gas plant; (2) conducting surface geophysical surveys; (3) drilling sediment borings and excavating pits or trenches; (4) installing monitoring weils in the unconsolidated sediments; and (5) coliecting sediment, waste, and ground-water for chemical anaiyses. Hydrogeoiogic information was obtained from geoiogic iogs recorded during driling and trenching operations and from surface geophysical data. The distribution of contaminants was delineated from driling and trenching logs (geologic) and from results of the chemicai anaiyses. Contaminants in sediments and hydrocarbon wastes were characterized from anaiyses of sampies collected during driiiing and trenching. Ground-water chemical information was obtained from anaiyses of sampies coliected from monitoring weils and from a seep. A reconnaissance of the bed of the Fiint River, upstream, adjacent to, and downstream of the study area was conducted to detect evidence of possible hydrocarbon contamination. 

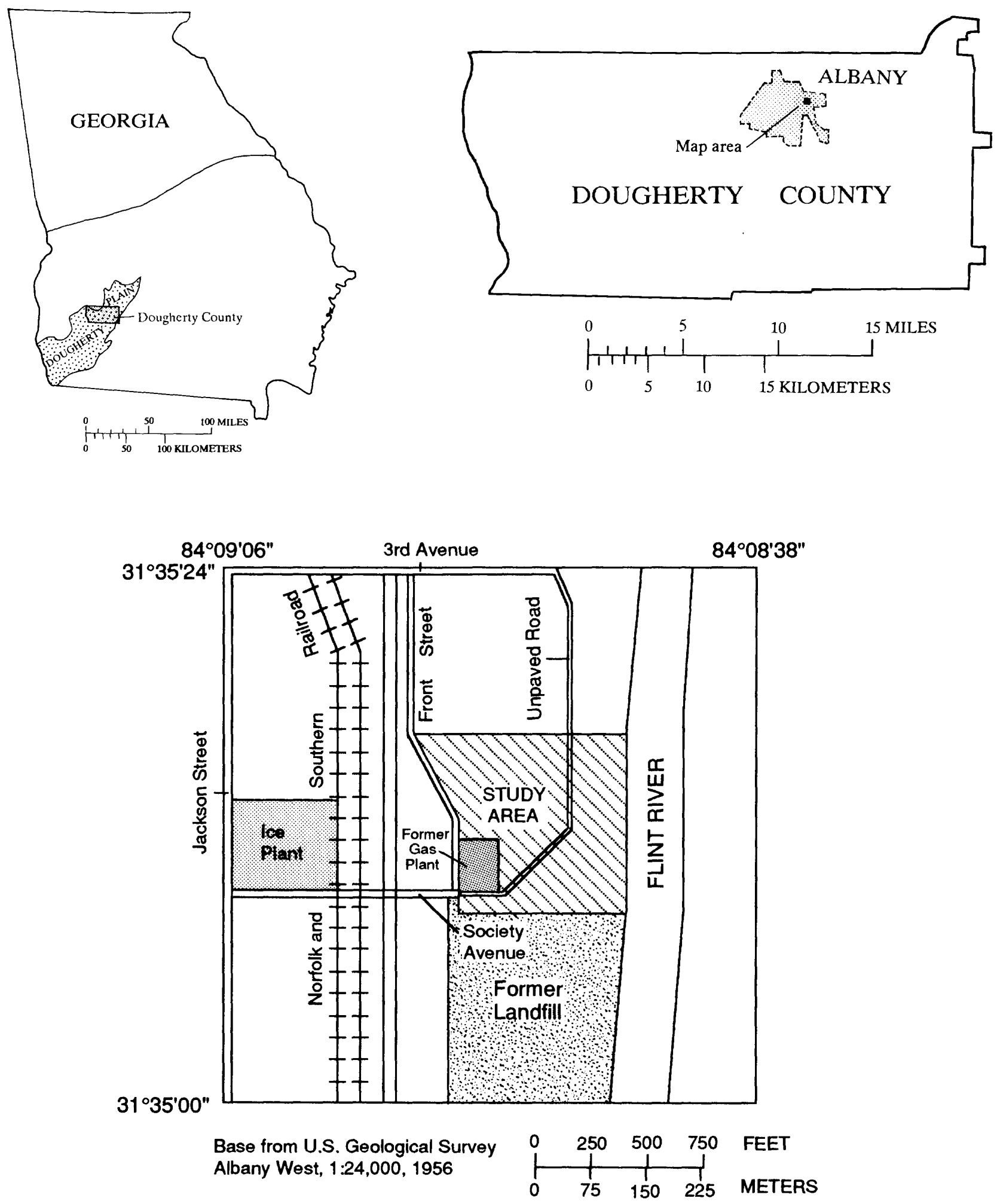

Figure 1.--Location of the study area, ice plant, gas plant, and former landfill in the Albany area. 


\section{Acknowledgments}

Many individuals assisted in the coilection and compilation of data for this report. The authors extend special thanks to U. Walter Rodemann, General Manager, Aibany Water, Gas, and Light Commission, for his support and assistance. Other members of the Albany Water, Gas, and Light Commission staff who were very helpful to the authors include Walter E. Olsen, James K. Goodin, Lee S. Coleman, Thomas B. Pittman, and James W. Skates.

Special appreciation is extended to Loris E. Asmussen and George A. Barfieid, U.S. Department of Agriculture, Agricultural Research Service, Tifton, Ga., for the use of their soil-sampling equipment and their support. Thanks also are extended to Homer D. Allison, Agricultural Research Service, for providing a ground-penetrating radar survey of the area.

The authors appreciate the historical research assistance provided by Dr. Jerry W. Devine and Janet $L$. Bean of the Thronateeska Heritage Foundation in Albany, Ga.

Appreciation is extended to Robert L. Atkins and Thomas J. Schmitt, Department of Natural Resources, Environmental Protection Division, Georgia Geologic Survey, for the loan of surfacegeophysical instruments used in this study.

\section{DESCRIPTION OF THE AREA}

The study area lies in the Dougherty Plain district of the Coastal Plain physiographic province of southwestern Georgia and encompasses about 12 acres in the central part of the city of Albany, Dougherty County, Ga. (fig. 1). The area is characterized by a relatively level topography with altitudes ranging from about 150 to $187 \mathrm{ft}$ above sea level. Most of the perimeter of the study area is enclosed by fencing. An unpaved road near the southern and eastern boundary of the study area provides access to the Flint River (figs. 1, 2).

The study area is bounded on the east by the Flint River, which flows within $600 \mathrm{ft}$ of the former gas plant. The Flint River, which originates near Atlanta, flows toward the southwestern corner of the State and is the principal surface-water drain for the Dougherty Plain (fig. 1). The average annual discharge of the Flint River at Albany is about 6,200 $\mathrm{ft}^{3} / \mathrm{s}$. The 7-day, 10-year recurrence interval low flow of the Flint River at the gaging station $0.44 \mathrm{mi}$ upstream from the study area is about $1,000 \mathrm{ft}^{3} / \mathrm{s}$ based on records for the period 1932-74 (Carter and Putnam, 1978). The minimum daily discharge of record is $327 \mathrm{ft}^{3} / \mathrm{s}$ (Stokes and others, 1989). Flow of the Flint River is sustained by ground-water discharge during periods of lowflow (U.S. Army Corps of Engineers, 1985).

The average rainfall for Albany is about $53 \mathrm{in}$./yr and ranges from 46 to $56 \mathrm{in}$./yr (minimum and maximum based on records collected from 1941-70) (Hayes and others, 1983). The greatest average monthly rainfall occurs in March, July, and August, and the driest months generally are October and November (U.S. Army Corps of Engineers, 1985). 

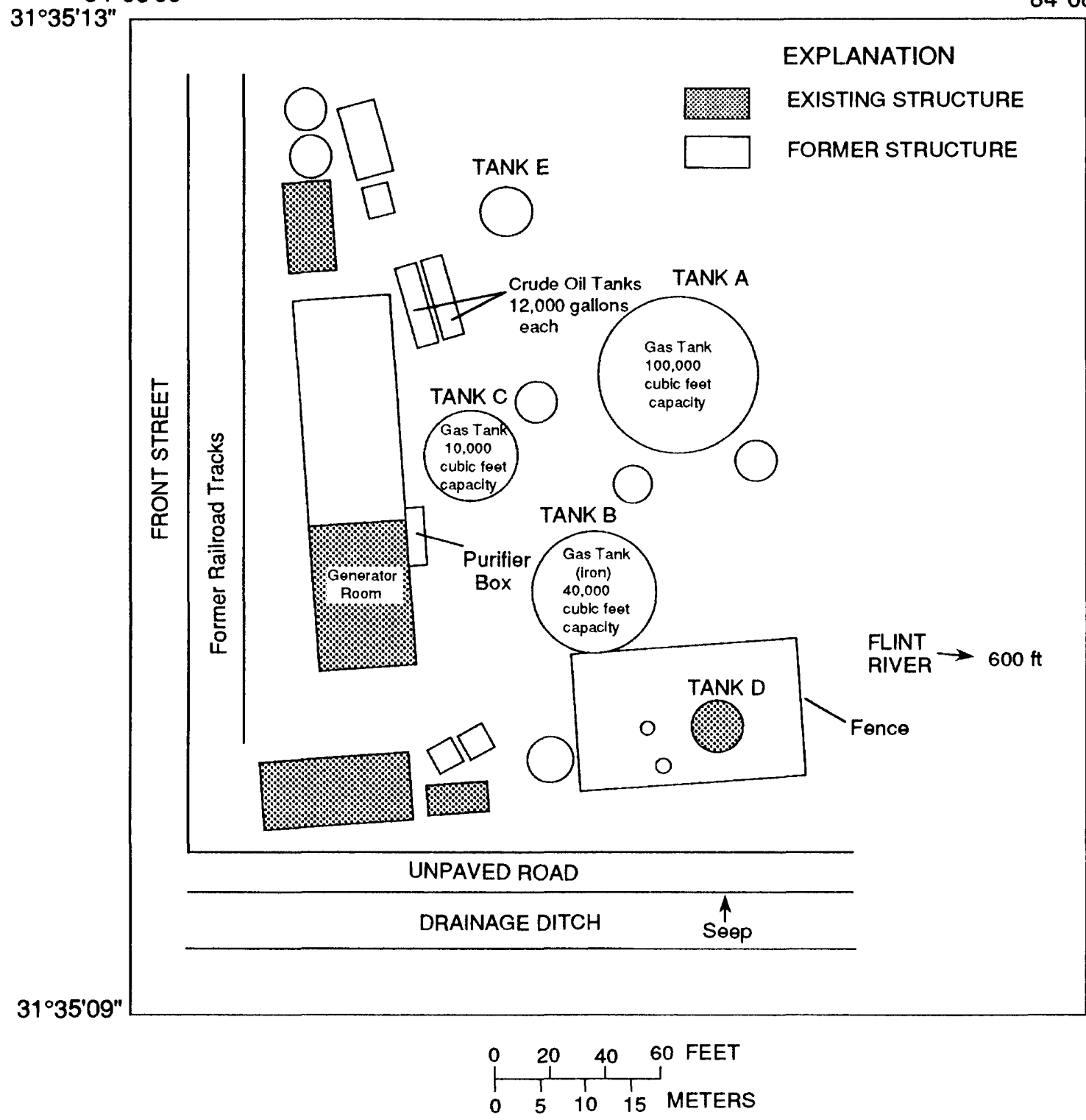

Figure 2.--General operational layout of the Albany gas plant.

\section{Land Use}

Land use surrounding the study area is designated as residential (single-family), commercial, and industrial within a 3-mi radius of the former gas plant. Residential housing is dominant but some mediumand light-commercial and industrial uses are present. Much of the area is covered by structures and pavement. About 85,000 people live in the city limits of Albany, which are within an $8 \mathrm{mi}$ radius of the study area. The total population of metropolitan Albany, including areas outside the city limits, is 117,200 (University of Georgia, 1989). Historic and current land use in the study area is discussed in the "Gas Plant" section of this report. 


\section{Water Use}

There are numerous wells within a 3-mi radius of the former gas plant. Domestic wells typically are less than $250 \mathrm{ft}$ deep and withdraw water from the Upper Floridan aquifer (Ocala Limestone). In general, the domestic wells are not used as a source of drinking water. Municipal supply wells provide drinking water for most of the residents in the area. Industrial and municipal supply wells withdraw water from aquifers below the Upper Floridan.

A major user of water from the Flint River in the Albany area is the Georgia Power Company's thermoelectric power plant, known as Plant Mitchell (U.S. Army Corps of Engineers, 1985), which is approximately $9.5 \mathrm{mi}$ south of the study area. The Flint River hydroelectric plant, located 1.3 river miles upstream of the study area, influences the stage of the Flint River in the vicinity of the former gas plant. Fishing is the major recreational use of the Flint River in the area.

\section{GAS PLANT \\ Pre-Operational History}

Research on the history of the Albany gas plant was conducted at the AWGLC offices, local libraries, and the local historical society. Literature concerning the growth and modernization of the city of Albany indicated that the gas plant was constructed in 1912. Fire insurance maps produced by the Sanborn Map Company in 1911, 1920, and 1930 were among the earliest maps of the area.

The property on which the former gas plant was constructed was used as the Dougherty County fairgrounds in the late 1800's and included an oval race track and ice-skating rink. The Artesian House Hotel also was in operation on the property during this period (Norris Wellge and Co., 1885). The property was purchased from Dougherty County by Boggs and MCNeill Lumber Company, and later resold to Reynolds Brothers' Lumber Company, which sawed and stacked lumber at the site. A part of the property was purchased by the Georgia Southwestern and Gulf Railroad, which later came under the ownership of the Atlantic Coast Railroad, and then the Norfolk-Southern Railway. A map produced by the Sanborn Map Company (1911) shows a machine shop, car-repair shop (presumably railroad car), railroad office building, coal incline, railroad water tower, and railroad oil holder on the property in 1911. By 1912, the city of Albany had purchased the property.

\section{Operational History}

The Albany gas plant operated for 36 yrs (1912-48). The layout of the gas plant as it existed during that period is shown in figure 2. During active operation of the plant, heavy, tar-based and oil-based byproducts were sold by the gallon to the general public. These materials were used for patching leaky roofs and for dust control on unpaved roads (J.W. Skates, AWGLC, oral commun., 1989). In addition, these byproducts accumulated in the gas holding tanks and periodically were released into the drainage ditch along the southern boundary of the gas plant property (fig. 2). Heavy, residual tar products are exposed along the banks of the ditch and along the banks of the Flint River at the confluence with the drainage ditch. This drainage ditch presumably was dug as an outlet to drain water from an ice manufacturing plant, located west of the study area (fig. 1). The ice manufacturing plant has been in existence since the 1880's.

Three of the original buildings from the gas plant are currently (1990) used as storage buildings by the AWGLC departments. The largest building, adjacent to Front Street, housed the generator room that contained boilers and retorts for gas production as well as a meter room (fig. 2). An elevated railroad trestle brought carloads of coal to this building to fire the boilers. 
South of the drainage ditch is the original landfill for the city of Albany (fig. 1). This landfill was operational until the early 1960's (Frank Cowart, Dougherty County Health Department, oral commun., 1989). The contents of the landfill are unknown; however, it was the only city landfill for many years and therefore, a wide variety of materials may have been dumped into this area. Aerial photographs of the gas plant and the adjacent property show that the surface of the landfill was graded by bulldozers several times prior to the 1960's (fig. 3).

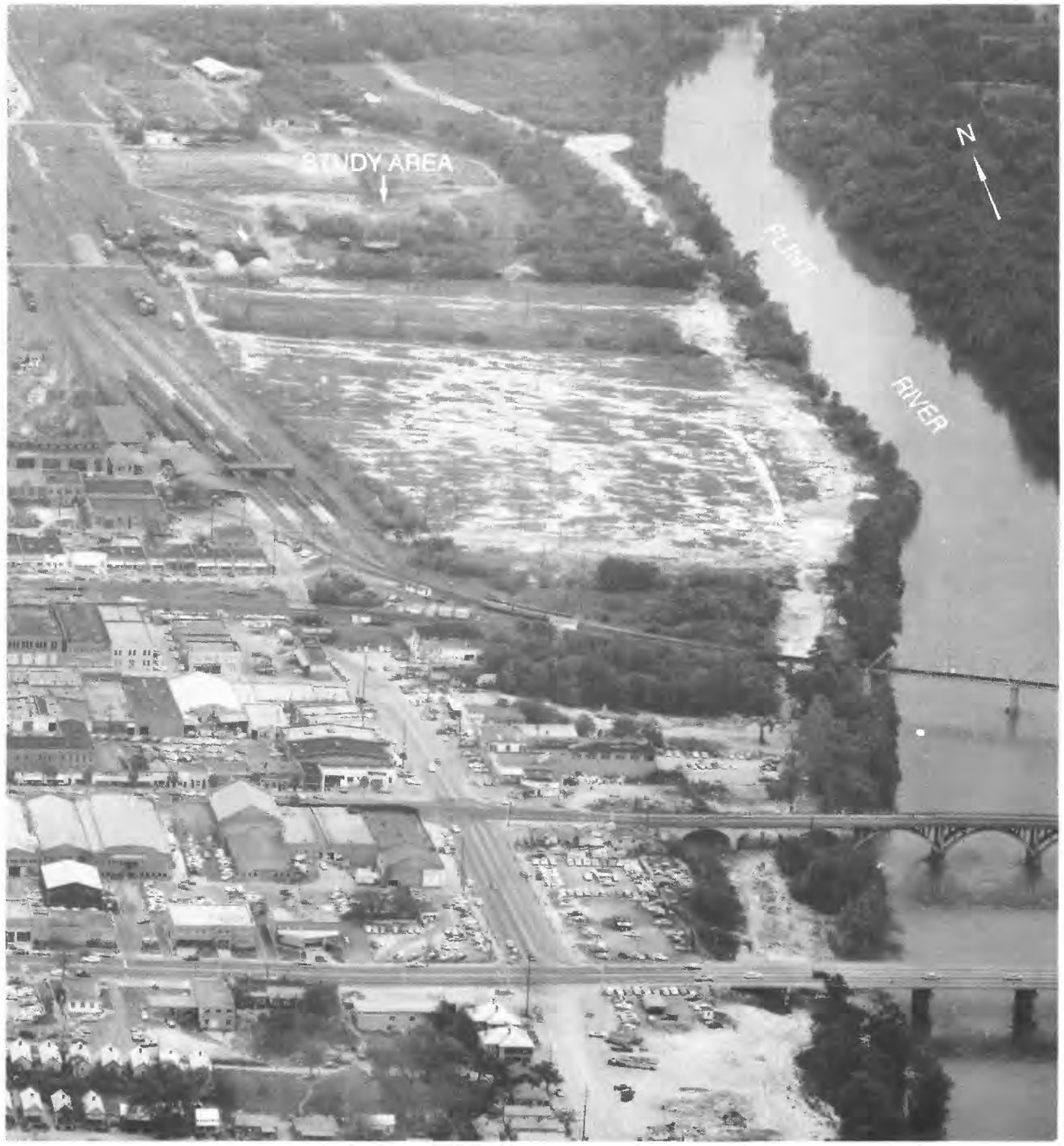

Figure 3.--Graded landfill south of the Albany gas plant, April 17, 1959. (Air Photography and Cartographic Service, Military Affairs Transportation Service). [Photograph from the Thronateeska Heritage Foundation, Albany, Georgia.] 
During the 36 yrs of gas production, flooding of the Flint River occasionally closed the Albany gas plant and destroyed its purifier boxes (only one known location, fig. 2). The purifiers were water-filled boxes containing lime and/or iron oxide as solid reactants, which aided in the removal of hydrogen sulfide from the gas (Gas Research Institute, 1987). The windows of the buildings eventually were sealed with brick to prevent flood waters from entering. There are several dramatic accounts of public efforts to sandbag around the Albany gas plant in order to save the "city gas works" from flooding in the 1920's. Many times these efforts failed and the city went for periods of weeks and months without gas for cooking, heating, and lighting. The Albany gas plant could not resume operation until the flood waters receded and the purifier boxes were repaired or rebuilt (The Albany Herald, January 19, 1925a).

The most severe flooding occurred in January 1925 when the flood stage of the Flint River exceeded $37 \mathrm{ft}$, and the estimated peak discharge was $92,000 \mathrm{ft}^{3} / \mathrm{s}$ (Stokes and others, 1989). A photograph of the gas plant during the 1925 flood was published in The Albany Herald on January 26, 1925 (fig. 4). Figure 5 shows the presence of numerous barrels at the Albany gas plant during a flood event.

Because of the devastating floods, a dike was built around the Albany gas plant and around Reynolds Brothers' Lumber Company. Drain pipes having one-way flapper valves were installed through the dike. The pipes extended in a radial fashion from the Albany gas plant. These pipes drained water from the area, and periodically were used to release excess by-products from the gas manufacturing process to the Flint River (J.W. Skates, AWGLC, oral commun., 1989). The only evidence of this release was observed in the drainage ditch along the southern boundary of the study area, where residual tar products are present.

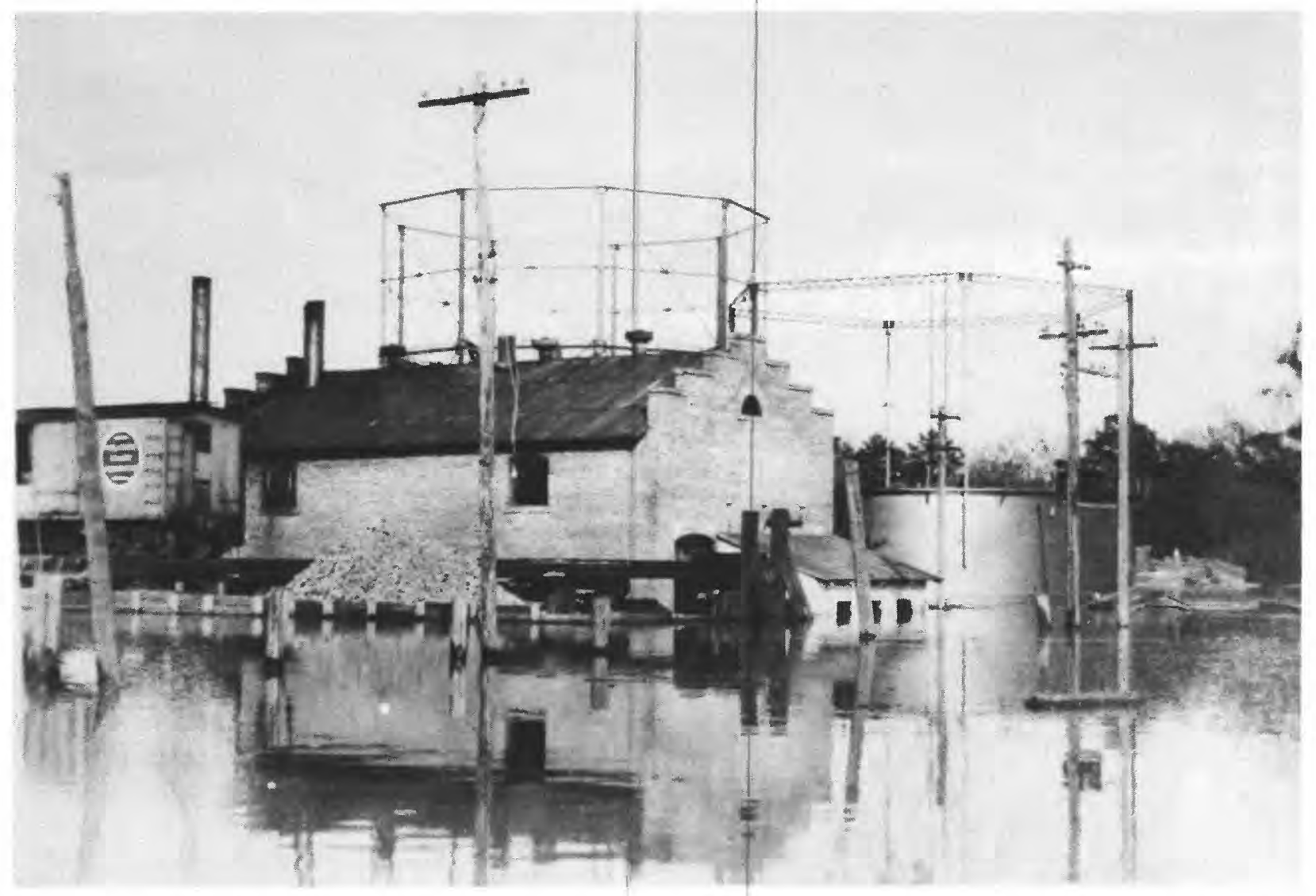

Figure 4.--Flooding of the Flint River at the Albany gas plant, January 1925 (Hart Studios). [Published in the Albany Herald on January 26, 1925. Photograph from the Thronateeska Heritage Foundation, Albany, Georgia.] 


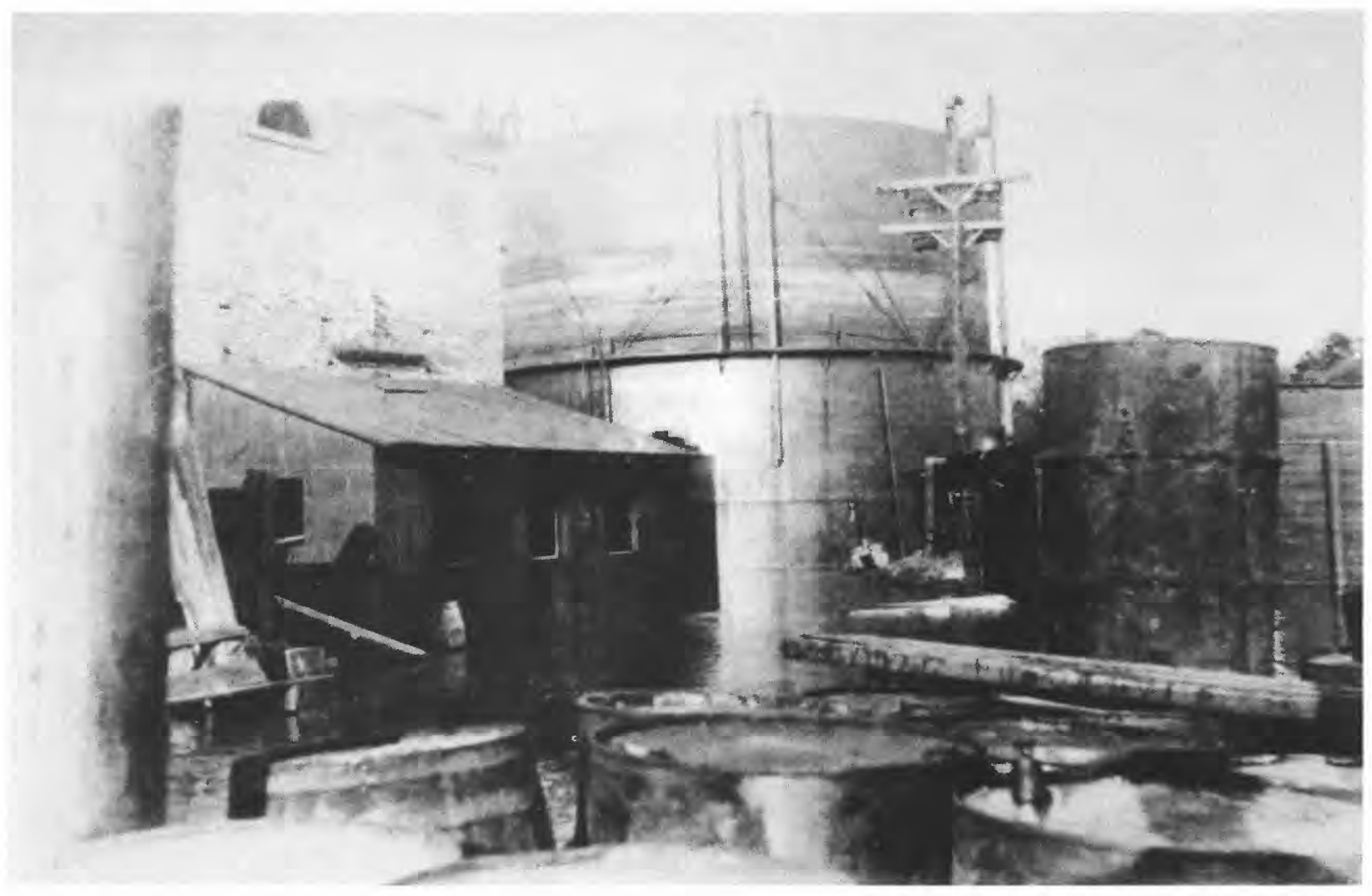

Figure 5.--Flooding of the Flint River and the presence of numerous barrels at the Albany gas plant. (Data and source unknown.) [Photograph from the Thronateeska Heritage Foundation, Albany, Georgia.]

\section{Decommissioning}

The Albany gas plant ceased operation and was abandoned in 1948 . However, the actual decommissioning and demolition of the plant structures were not completed until 1961. The large gas holding tanks (gasometers) (fig. 2) were given to a scrap-iron company in return for their cutting the tanks down and removing them from the property. An aerial photograph taken by the U.S. Department of Agriculture in 1953 showing the two largest tanks and numerous other tanks at the former gas plant is shown in figure 6. The oldest and original holding tank (tank B, fig. 2) had a capacity of $40,000 \mathrm{ft}^{3}$. Tank B, which was partially buried below land surface, was removed first, along with the metal framework that held the tank as it rose and fell as gas was added or removed. During decommissioning, the tank apparently was cut off at ground level, and the sides were pushed into the tank base with other refuse and fill (J.W. Skates, AWGLC, oral commun., 1989). The base of tank B, along with other debris, was not removed from the subsurface.

The largest gas holding tank (tank A, figs. 2, 7) had a capacity of $100,000 \mathrm{ft}^{3}$. All parts of tank A were removed from the subsurface; however, a large, open pool of by-product and water remained at land surface. This pool is clearly visible on aerial photographs taken in 1962 (Air Photography and Cartographic Service, 1962, fig. 8). The contents of a smaller tank (tank E, fig. 2) northwest of this pool may have drained or leaked into the pool, as indicated by the aerial photographs. In response to safety concerns, the AWGLC hired a sand-hauling company to fill the open pool where tank A had been located, and to cover the greater part of the property with a 6 - to 7 -ft thick layer of sand. 


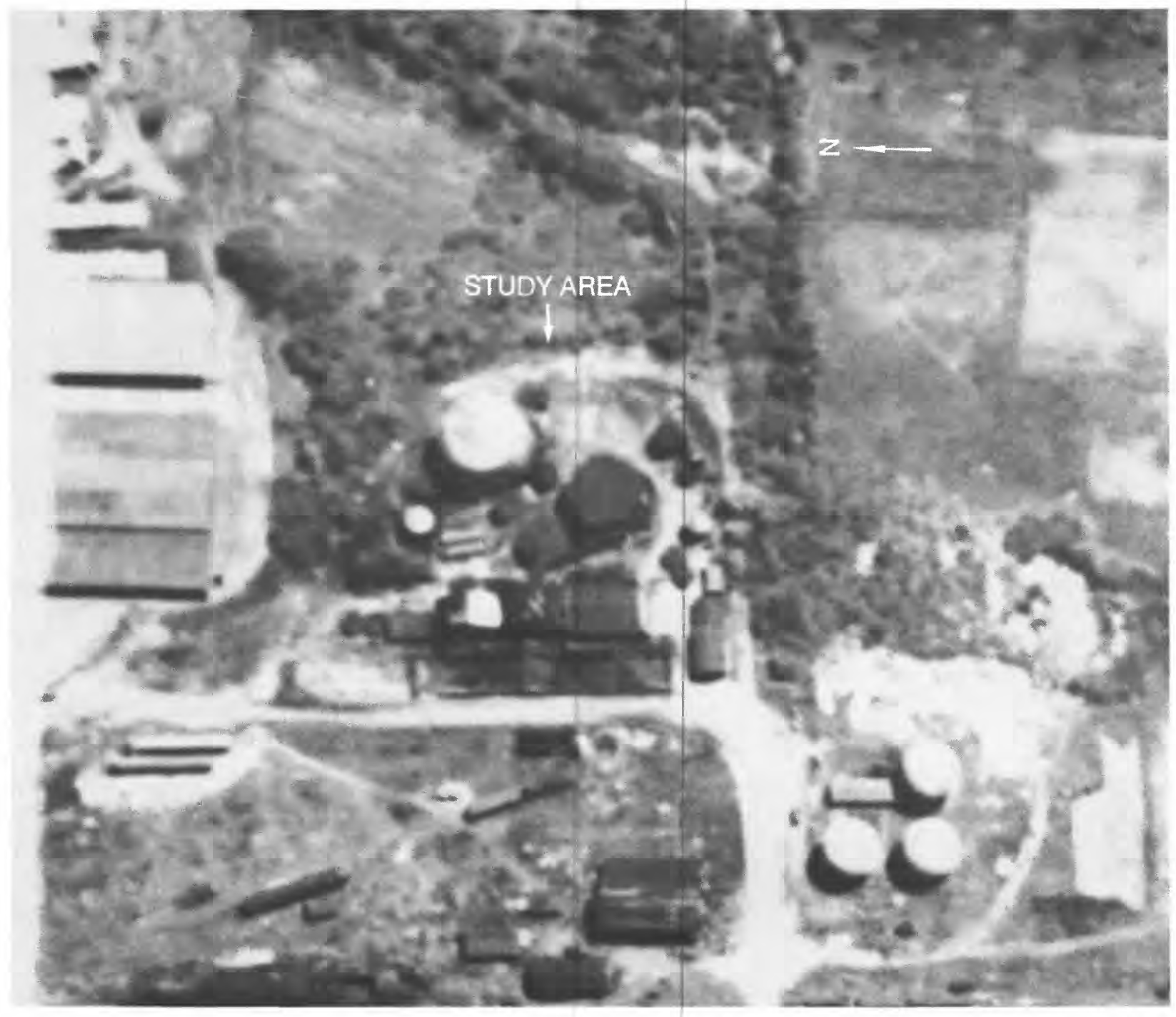

Figure 6.--Presence of numerous tanks at the former Albany gas plant, 1953. [Photograph from the U.S. Department of Agriculture, Agriculture Stabilization and Conservation Service, Salt Lake City, Utah.]

A $670-\mathrm{ft}^{3}$ capacity tank (tank D, fig. 2) remains intact on the former gas plant property. It is secured by a fence and is used by the Albany Department of Public Works as a holding tank for road-primer oil used for asphalt road paving.

Since the early 1960's, a part of the study area has been used as a landfill for nonhazardous solid waste generated by the work crews of the AWGLC departments. Generally, the materials dumped include old or damaged utility poles, tree limbs, soil, sand, concrete, and brick. 


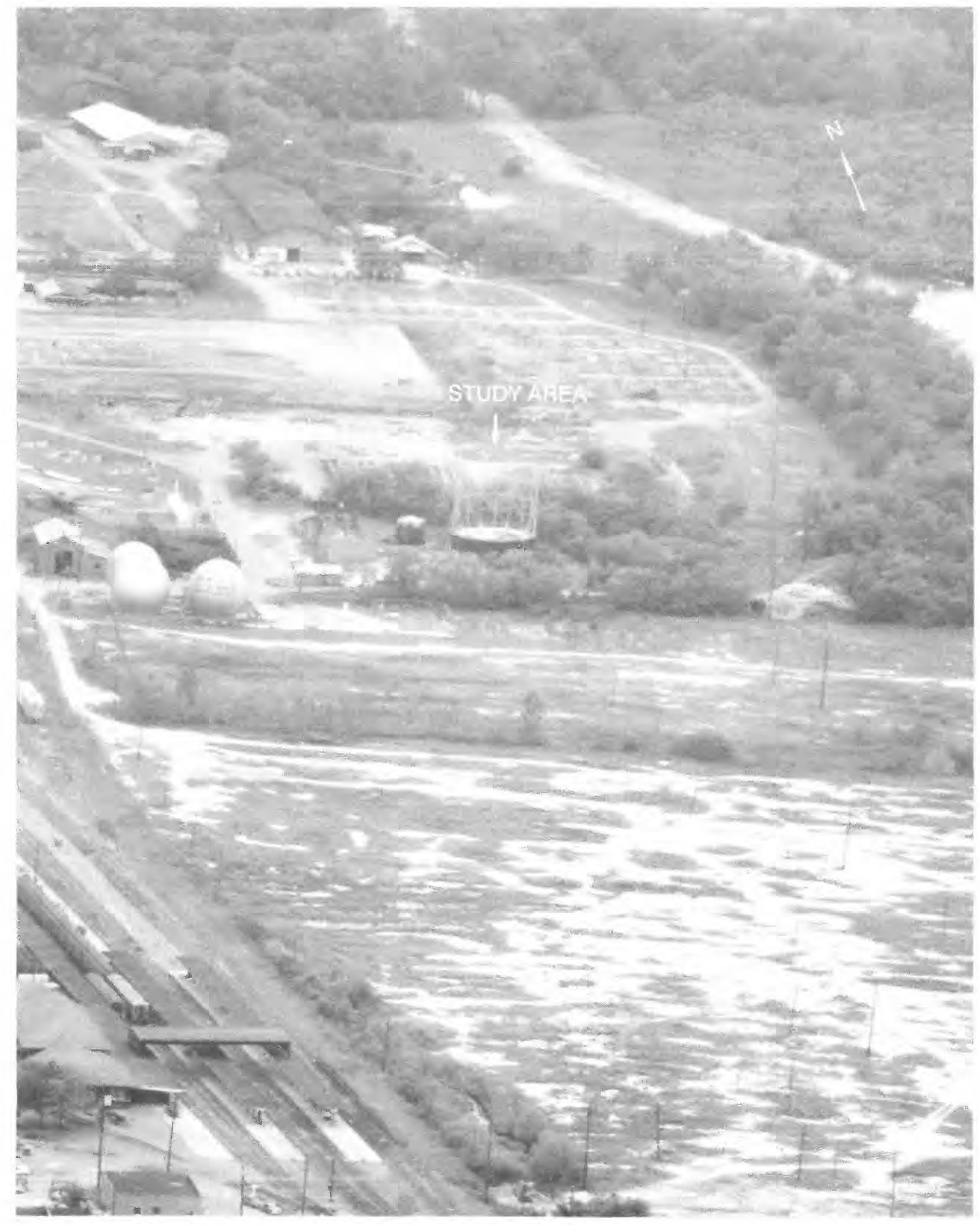

Figure 7.--The metal framework of the largest tank (tank A, fig. 2) at the former gas plant, April 17, 1959. (Air Photography and Cartographic Service, Military Affairs Transportation Service.) [Photograph from the Albany Chamber of Commerce]. 


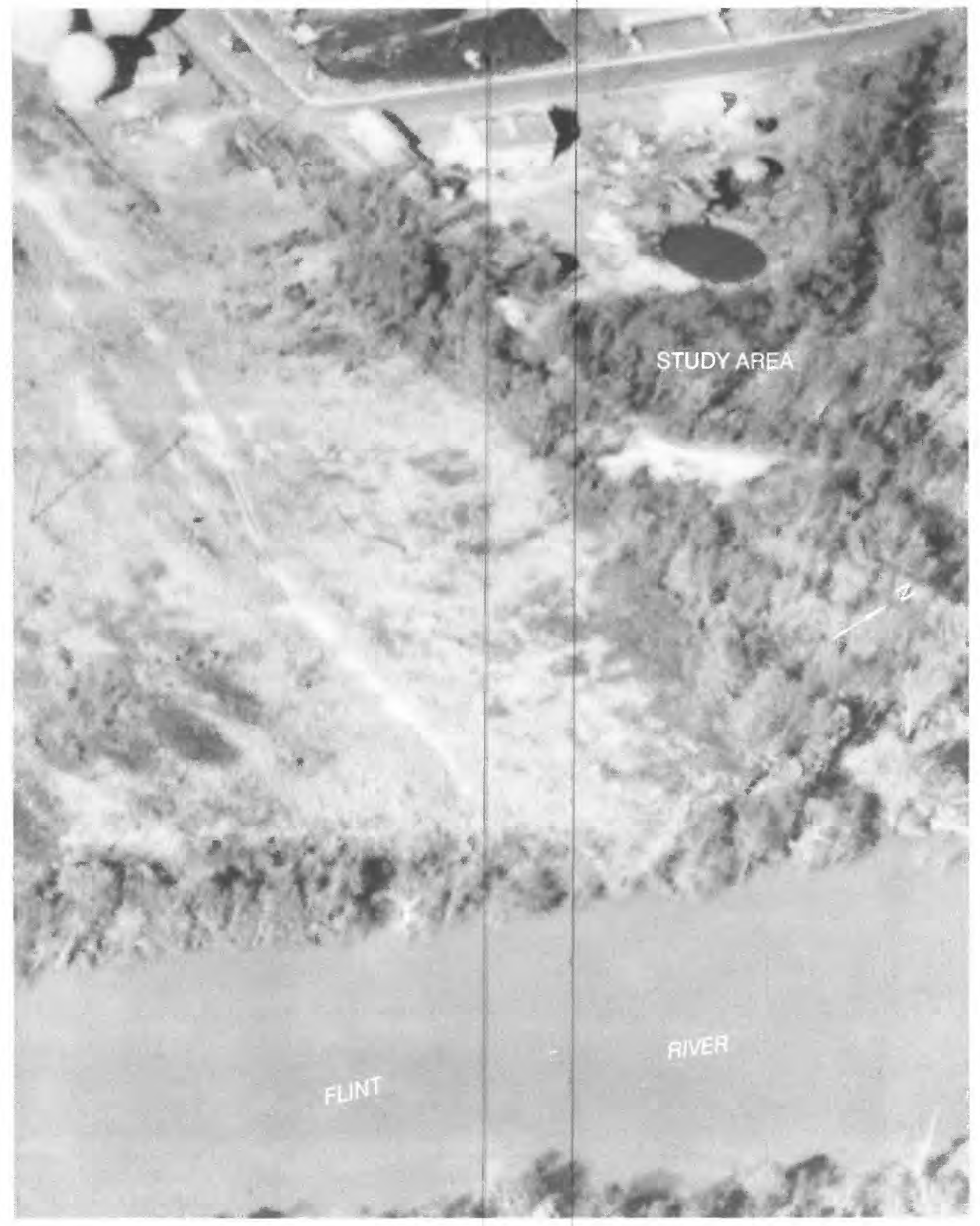

Figure 8.--A large, open pool of hydrocarbon liquid at the former gas plant after the removal of the largest tank (tank A, fig. 2), January 12, 1962. (Air Photography and Cartographic Service, Military Affairs Transportation Service). [Photograph from the Albany Chamber of Commerce.] 


\title{
GAS MANUFACTURING PROCESSES
}

\author{
AND \\ DESCRIPTION OF WASTES
}

Early fire insurance maps (Sanborn Map Company, 1920; 1930) describe the Albany gas plant as manufacturing "illuminating gas from crude oil" with "coke burning generators " and using two boilers for steam power. This description is consistent with the carbureted, water-gas manufacturing process (Edison Electric Institute, 1984).

The carbureted, water-gas process was the most prevalent method of manufacturing gas in the United States (Edison Electric Institute, 1984; Gas Research Institute, 1987). In the first stage of the process, steam was passed through an incandescent bed of coke to generate a combustible gas that was rich in hydrogen and carbon monoxide. This process formed tar as a byproduct. The heating value of the gas (blue gas) was enriched by thermal cracking of petroleum oils in the hot gas to add methane, ethane, and other light hydrocarbons. The gases were collected, cleaned by passage through a water-filled box (purifier box), and distributed; the byproduct was removed and sold, reused, or disposed of on site.

Two other prevalent manufactured gas processes were coal carbonization and oil gasification. Coal carbonization consisted of heating coal in a sealed chamber with destructive distillation of gas from the coal. Oil gas was made by thermal cracking of petroleum oils, similar to the second step of producing carbureted, water gas. The oil-gasification process primarily was limited to the West Coast of the United States.

The three processes produced similar byproducts, but there were important differences that affect both the current character of the wastes and their toxicity. Tar produced from coal carbonization contains large amounts of phenols, nitrogen-containing organic compounds, cyanides, and ammonia. The tar from carbureted water gas and oil gas contains only trace amounts of these compounds (EPA, 1988). 


\section{METHODS OF INVESTIGATION}

This phase of the study included several sequential steps of investigation

- a review of historical site records,

-- surface geophysical surveys,

- drilling of test borings,

-- excavation of test pits,

-- installation of shallow monitoring wells,

-- chemical analyses of sediment, wastes, and ground-water samples, and

-- characterization of demographic features.

A review of historic site records and interviews with AWGLC personnel (post gas plant operations) provided preliminary information on plant activities. This information was supplemented by an analysis of archived aerial photographs and maps. The records provided general information on the operational layout of the plant.

Surface geophysical techniques were used in an attempt to identify areas where hydrocarbons may be present in the subsurface, to determine possible refuse burial areas, and to establish vertical and lateral geologic boundaries. The techniques used included (1) magnetometry, (2) electromagnetic (EM) conductivity, (3) electrical resistivity, and (4) ground-penetrating radar. Thirty-five permanent geophysical stations were established in the study area. Readings of magnetic intensity were recorded at the geophysical data stations using a proton magnetometer. The Geonics EM34-3XL1/ instrument was used to record electromagnetic conductivity at the data stations. Five vertical electrical resistivity soundings were surveyed at various locations in the study area. Twenty-three ground-penetrating radar survey lines were run along and parallel to the geophysical data stations.

A preliminary examination of unconsolidated sediments was accomplished by completing shallow borings using hand augers or a tractor-mounted, solid-stem auger rig (table 1). Locations of the borings are shown in figure 9. Upon removal of the augers from the borehole, organic vapor concentrations in the hole were measured using either a Century Model 128 Organic Vapor Analyzer (OVA) or a HNU Model PI 101 Photoionization Detector. Locations having the most concentrated hydrocarbon staining and those having the highest organic vapor concentrations, generally were targeted for further investigation using hollow-stem augering methods. In addition, seven test pits were excavated with a backhoe to further describe the unconsolidated sediments.

A total of 33 borings were drilled into the unconsolidated sediments using solid-stem and hollowstem auger rigs (table 1). Twenty-one shallow boreholes, generally less than $10 \mathrm{ft}$ in depth, were drilled using the solid-stem auger rig. Twelve boreholes were drilled using the hollow-stem auger rig, one at a background site (HS-4) and 11 in the vicinity of the former gas plant structures (fig. 9). The drilling equipment was steam-cleaned after each borehole was drilled. Drilling fluids were not used.

Continuous cores were obtained from the land surface to the top of the Ocala Limestone at boreholes drilled with the hollow-stem auger. Cores were analyzed on-site with an OVA, and examined for discoloration and odors. From six of the boreholes, a sediment sample judged to be the most contaminated was selected for detailed chemical analysis. Brass core-barrel liners having Teflon-lined caps were used to collect sediment cores for the analysis of volatile organic compounds.

$1 /$ The use of brand names in this report is for identification purposes only and does not constitute endorsement by the U.S. Geological Survey. 
Table 1.--Inventory of borings and trenches in the unconsolidated sediments in the study area

[HS, hollow-stem auger boring; $B$, solid-stem auger boring;

TP, test pit (trench); --, no data]

\begin{tabular}{|c|c|c|c|}
\hline $\begin{array}{l}\text { Boring/ } \\
\text { test pit } \\
\text { number }\end{array}$ & $\begin{array}{c}\text { Date } \\
\text { drilled/ } \\
\text { excavated }\end{array}$ & $\begin{array}{l}\text { Depth } \\
\text { (feet) }\end{array}$ & $\begin{array}{l}\text { Land } \\
\text { surface } \\
\text { altitude } \\
\text { (feet) }\end{array}$ \\
\hline $\begin{array}{l}\text { HS-1 } \\
\text { HS-2 } \\
\text { HS-3 } \\
\text { HS-4 } \\
\text { HS-5 } \\
\text { HS-6 } \\
\text { HS-7 } \\
\text { HS-8 } \\
\text { HS-9 } \\
\text { HS-10 } \\
\text { HS-11 } \\
\text { HS-12 } \\
\text { B-1 } \\
\text { B-2 } \\
\text { B-3 } \\
\text { B-4 } \\
\text { B-5 } \\
\text { B-6 } \\
\text { B-7 } \\
\text { B-8 } \\
\text { B-9 } \\
\text { B-10 } \\
\text { B-11 } \\
\text { B-12 } \\
\text { B-13 } \\
\text { B-14 } \\
\text { B-15 } \\
\text { B-16 } \\
\text { B-17 } \\
\text { B-18 } \\
\text { B-19 } \\
\text { B-20 } \\
\text { B-21 } \\
\text { TP-1 } \\
\text { TP-2 } \\
\text { TP-3 } \\
\text { TP-4 } \\
\text { TP-5 } \\
\text { TP-6 } \\
\text { TP-7 }\end{array}$ & $\begin{array}{l}04-04-89 \\
04-04-89 \\
04-05-89 \\
04-05-89 \\
04-05-89 \\
04-05-89 \\
04-05-89 \\
04-06-89 \\
07-11-89 \\
07-12-89 \\
07-13-89 \\
07-13-89 \\
03-07-89 \\
03-07-89 \\
03-07-89 \\
03-07-89 \\
03-07-89 \\
03-07-89 \\
03-07-89 \\
03-07-89 \\
03-07-89 \\
03-07-89 \\
03-08-89 \\
03-08-89 \\
03-08-89 \\
03-08-89 \\
03-08-89 \\
03-08-89 \\
03-29-89 \\
03-29-89 \\
03-29-89 \\
03-29-89 \\
03-29-89 \\
05-03-89 \\
05-03-89 \\
05-03-89 \\
05-03-89 \\
05-03-89 \\
05-03-89 \\
05-03-89\end{array}$ & $\begin{array}{c}30.5 \\
23 \\
8 \\
14.5 \\
3 \\
7.5 \\
6 \\
14 \\
27.5 \\
24 \\
23.5 \\
17 \\
7 \\
5 \\
7 \\
8 \\
10 \\
8.5 \\
10 \\
10 \\
2 \\
1.5 \\
4.5 \\
4 \\
5 \\
4 \\
9 \\
3.5 \\
2.5 \\
10.5 \\
6.5 \\
9 \\
7.5 \\
1.3 \\
6.5 \\
5 \\
6.5 \\
7 \\
5 \\
5\end{array}$ & $\begin{array}{c}184.4 \\
185.0 \\
185.9 \\
185.6 \\
- \\
185.2 \\
184.0 \\
183.6 \\
183.6 \\
185.1 \\
184.1 \\
- \\
- \\
- \\
185.9 \\
- \\
- \\
- \\
- \\
- \\
- \\
- \\
- \\
- \\
- \\
- \\
- \\
- \\
- \\
- \\
- \\
- \\
- \\
- \\
-\end{array}$ \\
\hline
\end{tabular}




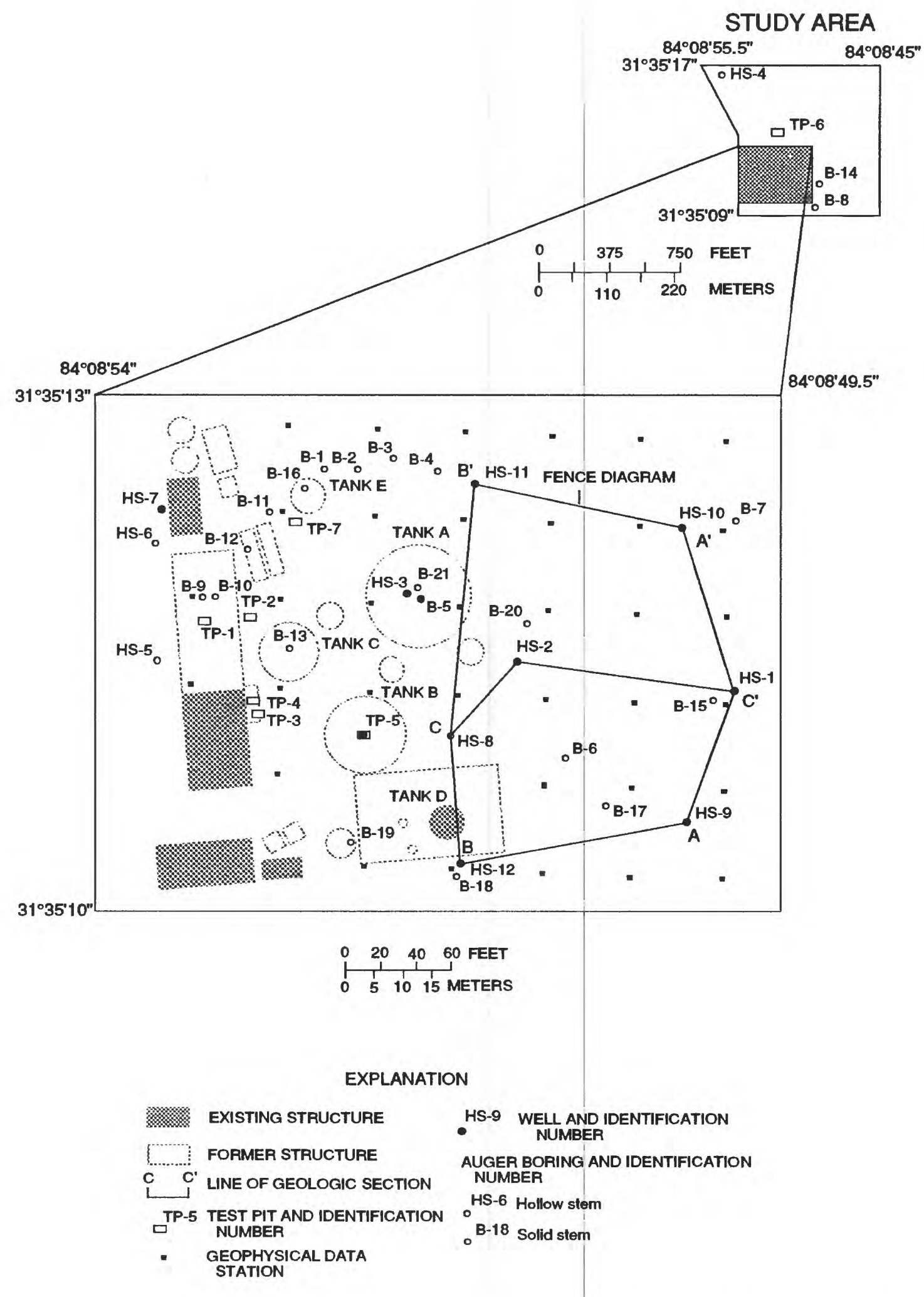

Figure 9.--Locations of geologic sections, fence diagram, auger borings, test pits (trenches), wells, and geophysical data stations in part of the study area. 
Monitoring wells were completed in nine boreholes and one back-filled excavation pit using polyvinylchloride (PVC) casing and screens (table 2). Screens for wells B-5, HS-3, and HS-7 were set in the upper sand, above the upper clay. Screens for wells HS-1, $-2,-9,-10,-11$, and -12 were set in the deeper, lower sand. Well TP-5, which was located in an excavation pit that had been filled was screened in sandy fill material at about the depth of the base of tank B (figs. 2 and 9).

Table 2.-Inventory of wells in the unconsolidated sediments in the study area

[HS, hollow-stem auger boring; $B$, solid-stem auger boring;

$T P$, test pit (tronch); -, no data]

\begin{tabular}{|c|c|c|c|c|c|c|c|}
\hline $\begin{array}{c}\text { Well } \\
\text { number }\end{array}$ & $\begin{array}{c}\text { Date } \\
\text { drilled/ } \\
\text { excavated }\end{array}$ & $\begin{array}{l}\text { Depth } \\
\text { (feet) }\end{array}$ & $\begin{array}{l}\text { Depth of } \\
\text { casing } \\
\text { (feet) }\end{array}$ & $\begin{array}{c}\text { Screen } \\
\text { length } \\
\text { (feet) }\end{array}$ & $\begin{array}{l}\text { Land } \\
\text { surface } \\
\text { altitude } \\
\text { (feet) }\end{array}$ & $\begin{array}{c}\text { Water level } \\
\text { altitude } \\
\text { (feet) }\end{array}$ & $\begin{array}{c}\text { Date of } \\
\text { water-level } \\
\text { measuremen }\end{array}$ \\
\hline \multirow[t]{2}{*}{$1 / \mathrm{HS}-1$} & 04-04-89 & 30.5 & 20.5 & 10 & 184.4 & 154.3 & $04-04-89$ \\
\hline & $04-04-89$ & 30.5 & 20.5 & 10 & 184.4 & 163.7 & $04-14-89$ \\
\hline HS-2 & $04-04-89$ & 23 & 18 & 5 & 185.0 & 168.6 & $04-14-89$ \\
\hline HS-3 & $04-05-89$ & 8 & 3 & 5 & 185.9 & - & - \\
\hline HS-7 & $04-05-89$ & 6 & 3.5 & 2.5 & 185.2 & - & - \\
\hline HS-9 & $07-11-89$ & 27.5 & 17.5 & 10 & 183.6 & 159.6 & $07-11-89$ \\
\hline HS-10 & $07-12-89$ & 24 & 14 & 10 & 183.6 & - & - \\
\hline HS-11 & $07-13-89$ & 23.5 & 18.5 & 5 & 185.1 & - & - \\
\hline HS-12 & $07-13-89$ & 17 & 12 & 5 & 184.1 & - & - \\
\hline B-5 & $03-07-89$ & 10 & 5 & 5 & 185.9 & 177.9 & $04-21-89$ \\
\hline TP-5 & $05-03-89$ & 7 & 2 & 5 & 184.8 & 180.3 & $05-01-89$ \\
\hline
\end{tabular}

1/Continuous water-level recorder installed 04-27-89

Wells were installed by inserting casing through the hollow-stem auger and removing the auger flights. Graded sand was poured in the well annulus until the sand pack extended to about $2 \mathrm{ft}$ above the top of the well screen. A bentonite seal ( $2 \mathrm{ft}$ minimum thickness) was placed over the sand pack and along clay horizons. The holes then were backfilled with native sediments to land surface. A protective, lockable, steel well cover was installed around the PVC casing, and was anchored with a concrete surface pad which also provided a seal around the well casing at land surface.

Monitoring wells were constructed of factory-cleaned, 2-in. diameter, flush-threaded, PVC well casing and 0.010-ft slotted PVC screen. Screen length and vertical placement were selected to allow monitoring of anticipated water-table fluctuations and the collection of any contaminants floating on water in the aquifer.

Subsequent to development by hand bailing, each well was allowed to stabilize for several days. Then, an initial round of ground-water samples was collected by bailing using a dedicated (one bailer per well) PVC or Teflon bailer using techniques outlined by Brown and others (1970) and Wood (1976). These samples were then submitted to U.S. Geological Survey laboratories for analyses for organic constituents, cyanide, metals, and total organic carbon. 
Sediment, waste, and ground-water samples were analyzed for more than 30 volatile (purgeable) organic compounds and 50 semivolatile (methylene chloride-extractable) organic compounds. Identification of these specific target compounds was by gas chromotography/electron impact mass spectrometry (GC/MS), and confirmed by comparison with standard samples. Computerized scans using the National Bureau of Standards (written commun., 1990) mass spectrum library also were conducted to tentatively identify additional non-target compounds. The selection of constituents for analysis was based on their known presence in coal tar and their listing by the EPA (1986) as potentially harmful to human health and/or the environment.

\section{HYDROGEOLOGY \\ Surficial Fill Material}

Surficial materials in the study area consist of a wide variety of artificial or man-made fill including sand, clay, gravel, brick, concrete, lumber, and metallic debris. The thickness of the fill ranges from about 2 to $10 \mathrm{ft}$. The wide variety of composition of the surficial fill causes infiltration rates of rainfall and surface runoff to vary greatly. Standing water was observed north-northeast of the area of former tank A (fig. 2) following periods of heavy rainfall. This area is topographically lower than the surrounding area, which causes runoff to drain in its direction. Runoff accumulates in this area owing to an increased clay content in the fill, which reduces infiltration rates.

\section{Unconsolidated Sediments}

The lithology of the unconsolidated sediments, alternative sand and clay layers, varies throughout the study area. The geologic origin of the sediments (Quaternany Age) is unknown, but may be related to processes in the evolution of the Flint River. The composition of the sand layers ranges from very clean, coarse sand to clayey, fine sand. Generally, the clay layers are sandy, but in some areas they are less sandy and locally may have low hydraulic conditivity. Vertical and horizontal fractures in the clay layers are common. Fractures having vertical orientations usually are located near the upper surface of the clay layers, and those having horizontal orientations are found lower and within the layers (Supplemental Data). Where the percentage of clay in a sand layer is higher, the permeability of the sand is lower. Where the percentage of sand in a clay layer is higher, the permeability of the clay is higher. The clay layers commonly restrict the vertical movement of ground water, whereas the sand layers, which are more permeable, generally are water-bearing units.

Most of the study area is underlain by restrictive clay layers, except in the southeastern area where the clay layers seem to pinch out in the vicinity of well HS-9 (fig. 10). The clay layers progressively thicken to the west and away from the Flint River. 


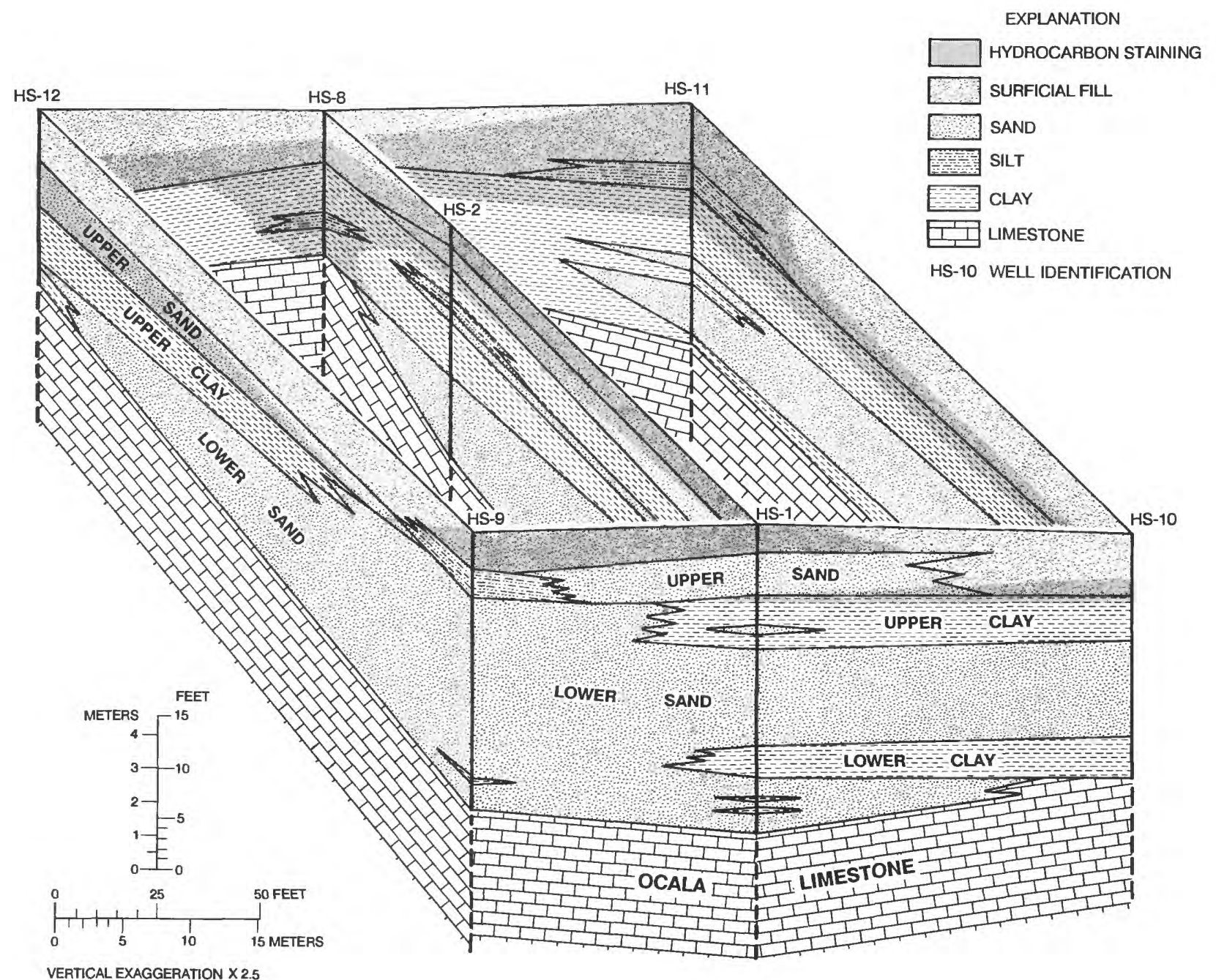

Figure 10.--Generalized schematic fence diagram showing lithology of an area adjacent to the abandoned gas plant (Trace of fence diagram shown in figure 9.)

The clay layers range in depth from about 4 to $10 \mathrm{ft}$ below land surface, and they range in thickness from 0.5 to $6.5 \mathrm{ft}$. The top surface of the upper clay layer seems to be irregular and it has a wide range of direction and slope (from 0.2 to $7.4 \mathrm{ft}$ in $100 \mathrm{ft}$ of horizontal distance). The altitude of the top of the upper clay layer appears to be lower in the vicinity of boring B-18 and well HS-12 than in the surrounding area (fig. 11). The lower clay layer occurs at depths that range from 20.0 to $22.5 \mathrm{ft}$ (fig. 10). 


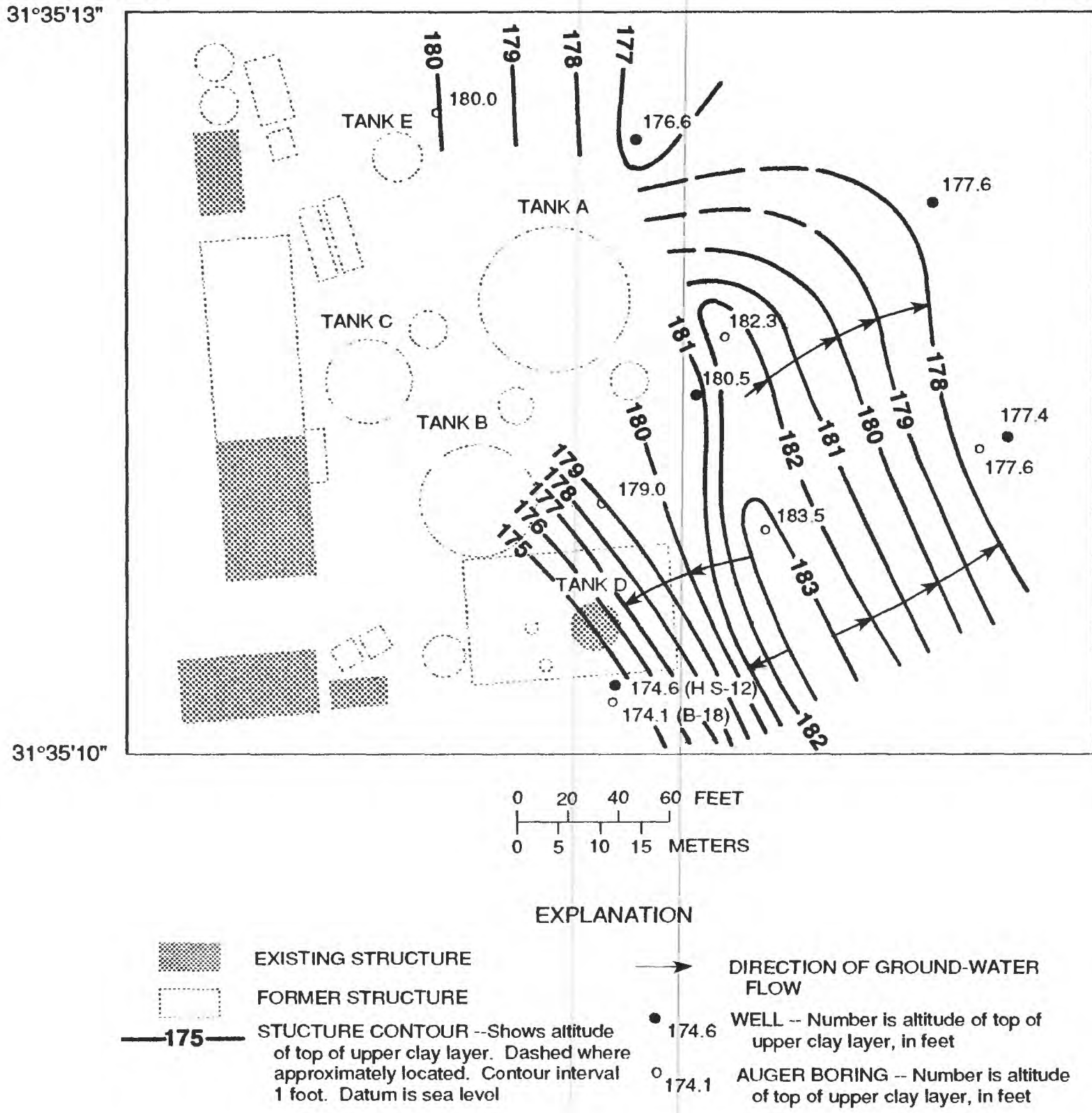

Figure 11.--Altitude of the top of the upper clay layer and general direction of ground-water flow in the upper sand layer.

Two sand layers that are seasonally saturated are present in the unconsolidated sediments: a shallow, upper sand layer having a perched water table; and a lower sand layer that is in contact with the Ocala Limestone (fig. 10). The upper clay layer restricts the vertical movement of ground water and hydraulically separates the two sand layers. The upper sand layer receives recharge from the infiltration of direct rainfall or ponded water. The water level in the lower sand layer responds to stage fluctuations of the Flint River (fig. 12). 


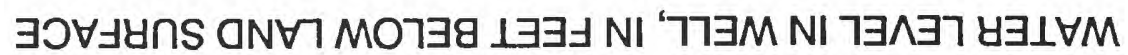

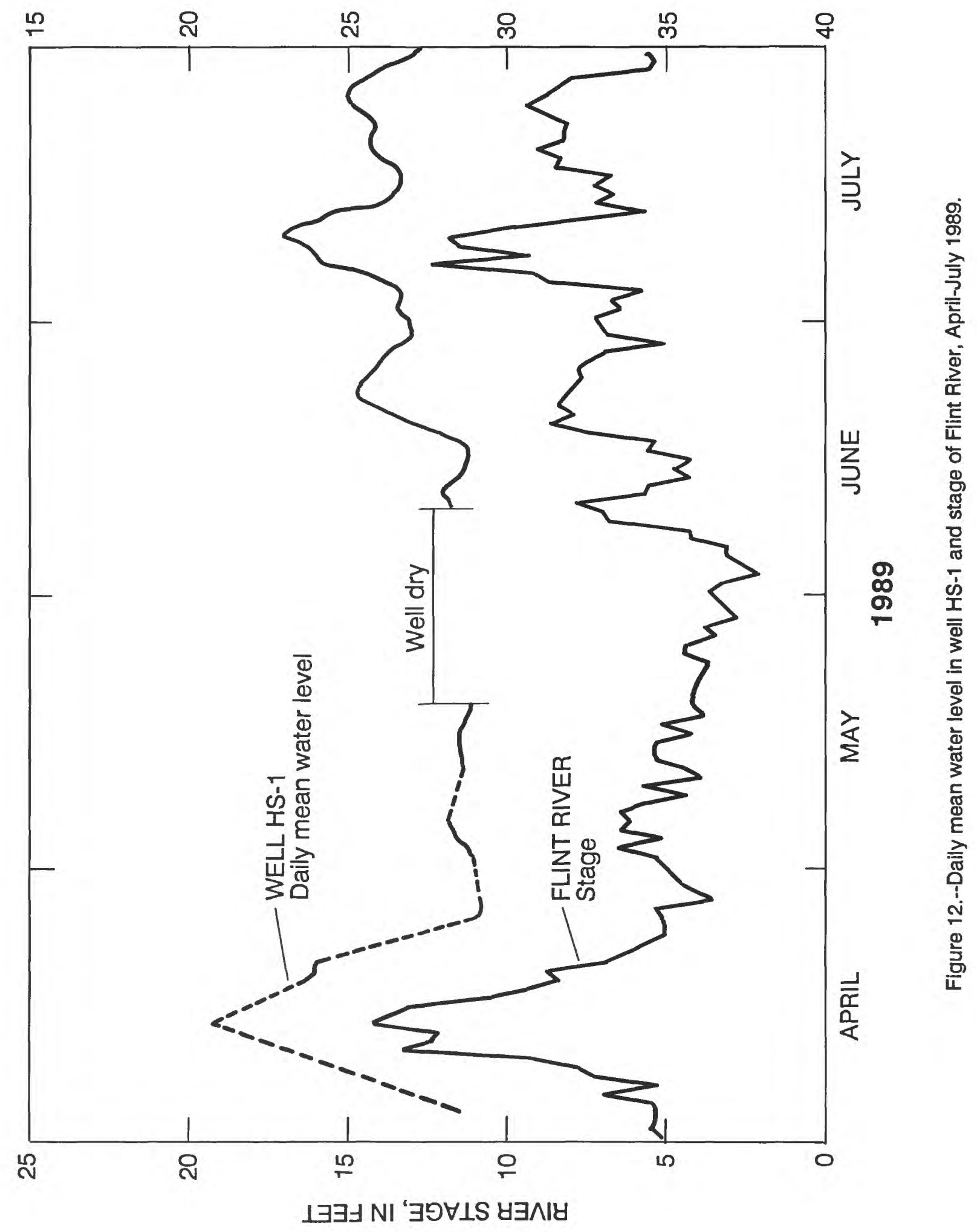


Water in the shallow, upper sand layer most likely flows in the downslope direction of the top surface of the upper clay layer. A seep along the northern bank of the drainage ditch, near the southern edge of the study area, allows ground water to discharge from the bank at the contact between the clay layer and the surficial fill (fig. 2). The altitude of the clay layer is lower near at the drainage ditch (boring B18 and well HS-12) than in the surrounding area. Estimated directions of ground-water flow along the upper sand layer and upper clay layer contact are shown in figure 11.

\section{Ocala Limestone}

The Ocala Limestone, of late Eocene age, which is a fossiliferous, fine-grained, chalky, crystalline limestone that contains layers of sandy limestone and crystalline dolomitic limestone, underlies the unconsolidated sediments of sand and clay in the study area. The Ocala Limestone comprises most of the Upper Floridan aquifer in the Albany area and ranges in thickness from 100 to $200 \mathrm{ft}$ (Hicks and others, 1987).

The altitude of the top of the Ocala Limestone in an area just east of the abandoned gas plant is shown on figure 13. In general, the altitude of the top of the limestone is lower to the east, toward the Flint River. The depth to the top of the Ocala Limestone ranges from about 14.0 to $30.5 \mathrm{ft}$ below land surface.

\section{Lisbon Formation}

The Lisbon Formation (middle Eocene) consists of dense, argillaceous, fossiliferous, sandy, glauconitic limestone and thinly interlayered calcareous sandstone and clay, and underlies the Ocala Limestone. The thickness of the Lisbon Formation can be as much as $100 \mathrm{ft}$ in the Albany area (Hicks and others, 1987). In extreme northern Dougherty County, the upper part of the Lisbon Formation has significant secondary permeability and is included in the Upper Floridan aquifer system. The lower part of the Lisbon Formation, generally considered to be less permeable, can serve as a lower confining unit for the Upper Floridan aquifer (Hicks and others, 1987).

\section{GROUND WATER \\ Monitoring Wells and Ground-Water Levels}

Most of the wells that tap the lower sand layer that is in contact with the Ocala Limestone were dry at the time of installation, except wells HS-1 and HS-9, which had water-level altitudes of $154.3 \mathrm{ft}$ and 159.6 $\mathrm{ft}$, respectively. Well HS-1 was drilled in April 1989 after a relatively dry winter, and well HS-9 was drilled in July 1989 after above-normal rainfall during late spring and early summer.

One well that taps the upper sand layer generally has had a measurable water level since it was drilled. The water level in well B-5 has remained at an altitude of about $177.9 \mathrm{ft}$ throughout the study period. The hydraulic head differences between the upper sand (having a water level of about $178 \mathrm{ft}$ ) and the lower sand (having a water level range of about 154 to $160 \mathrm{ft}$ ) indicates that the upper clay layer that separates the two sand layers does restrict vertical ground-water flow. 

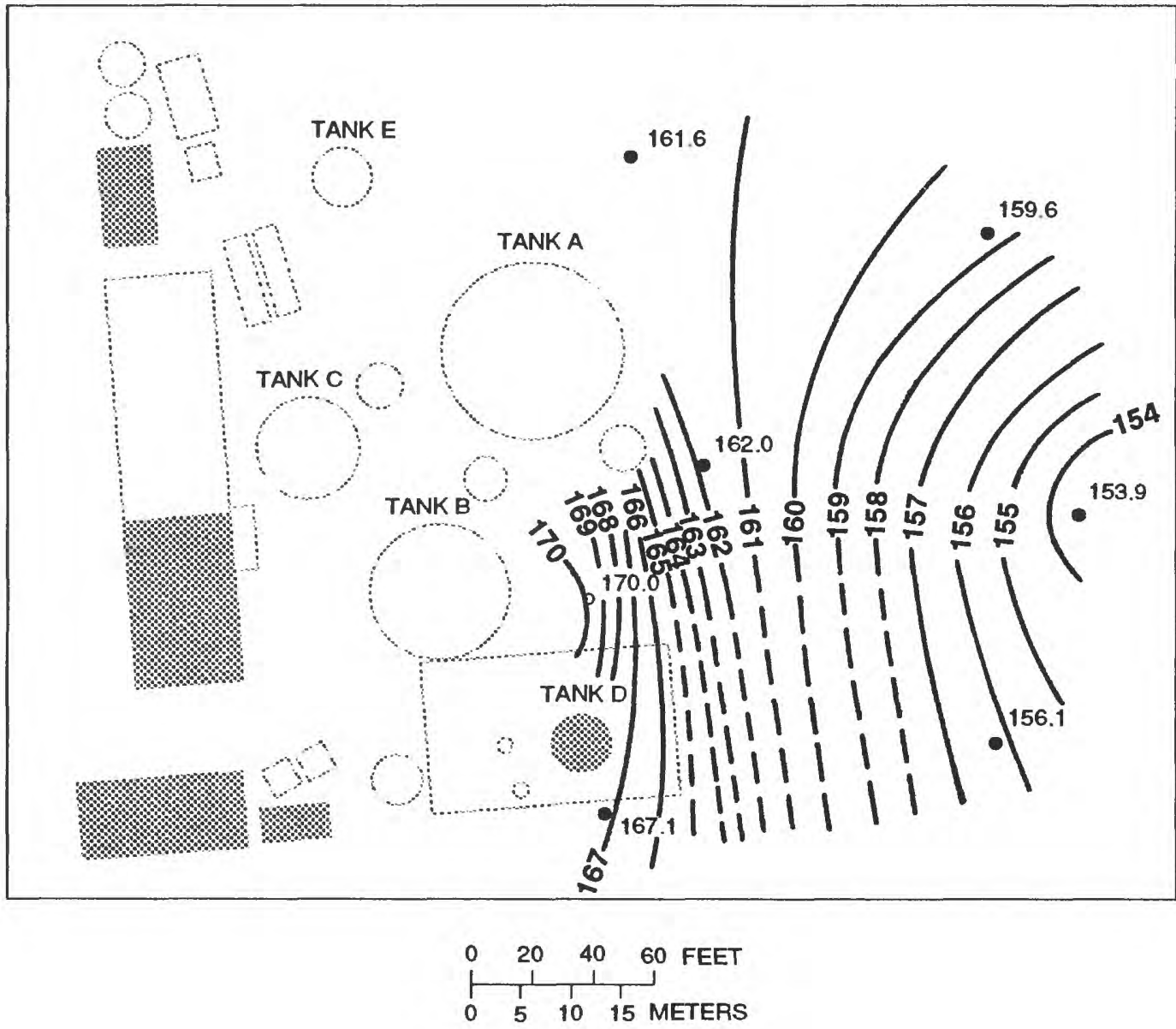

\section{EXPLANATION}

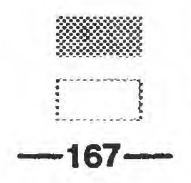

EXISTING STRUCTURE

FORMER STRUCTURE

STRUCTURE CONTOUR -- Shows

altitude of top of Ocala Limestone.

Dashed where approximately located.

Contour interval 1 foot. Datum is sea level

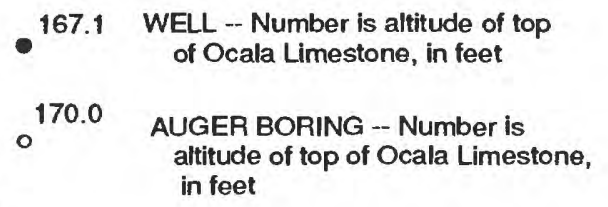

Figure 13.--Altitude of the top of the Ocala Limestone.

\section{Ground-Water and Surface-Water Relations}

Observations from well HS-1 indicate that the water level in the lower sand responds to changing river stage. Well HS-1 is approximately $450 \mathrm{ft}$ west of the Flint River. A water-level recorder was installed on well HS-1 when the stage of the Flint River had risen as a result of heavy rainfall during April 1989. At the time when the river stage rose, the water level in well HS-1 was at an altitude of $163.7 \mathrm{ft}$ and well HS-2 had a water-level altitude of $168.6 \mathrm{ft}$. Well HS-2 was dry during most of the period of this study, and contained water only during the higher stage of the Flint River in April 1989. 
Continuously recorded water-level data from well HS-1 confirmed that the water level in the well was related closely to stage fluctuations of the Flint River. Figure 12 shows fluctuations in stage of the Flint River at the gage approximately $0.44 \mathrm{mi}$ upstream from the study area and the fluctuations of the water level in well HS-1. Peaks in the hydrograph of the well coincide with peaks in the river stage during early spring; however, peaks in the ground-water level in June and July occur 2 to 4 days after the peaks in the river stage. From late May through early June, well HS-1 was dry, which coincides with the period of the lowest stage of the river. Overall, there seems to be a direct relation between the water level in well HS-1 and the stage of the Flint River.

\section{SURFACE GEOPHYSICS}

Surface geophysical surveys were used to obtain data needed to delineate the geologic framework of the unconsolidated sediments overlying the Ocala Limestone, and to evaluate the effect of previous land-use activities. The surveys used included magnetometry, electromagnetic (EM) conductivity, electrical resistivity, and ground-penetrating radar (GPR). Each type of survey provided data that were essential to the evaluation of the hydrogeology and location of buried debris of the study area. For more accurate interpretations, the results obtained by each survey were compared with data collected from test/exploratory borings and trenching, from laboratory analyses, and from data collected during other surface geophysical surveys.

\section{Magnetic Intensity}

Magnetometers measure the intensity of the Earth's magnetic field, and this intensity is influenced by the presence of iron objects in the subsurface (Benson and others, 1983). These instruments have been used in other investigative studies (Benson and others, 1983; Gilkeson and others, 1986) to locate buried drums, pipes, and tanks. The instrument reads in direct units of magnetic intensity (gammas), and interpretations of the data can be made in the field. The use of this method can be limited by (1) the presence of iron objects, such as fences on the surface, and (2) high background iron concentrations in sediments or rocks that reduce the contrast in iron objects in the subsurface.

Magnetic intensity readings were recorded at each of the geophysical data stations. A large iron anomaly (negative) was discovered in the vicinity of tank B (fig. 2). Lines of equal magnetic intensity of 50,000 gammas and less are centered around buried tank $B$, which results in a circular pattern in the magnetic intensity data (fig. 14). The anomaly consists of a decrease in magnetic intensity, from about 50,000 to 44,846 gammas, which indicates a large iron target (presumably the base of tank B is about $48 \mathrm{ft}$ in diameter). (This anomaly is defined by magnetometer readings recorded at 5 -ft intervals in radial survey lines out from the center of the tank. All data points could not be shown on figure 14.) Subsequent trenching confirmed the presence of the tank base at about $7 \mathrm{ft}$ below land surface.

\section{Electromagnetic Conductivity}

Electromagnetic conductivity (EM) instruments measure the conductivity of subsurface materials, and are sensitive to materials such as metallic debris and clay layers, as well as conductive or resistive contaminants. These instruments can be used to obtain direct apparent conductivity readings in millimhos per meter $(\mathrm{mmhos} / \mathrm{m})$ in the field, which allows for immediate interpretation. Locations of buried metallic pipes, tanks, and drums can be delineated in the field using EM instruments. The areal extent of contaminants and conductive clay layers also can be estimated in the field. Relative depths to clay layers can be estimated by personnel experienced in the interpretation of the EM readings. Limitations of this surface geophysical method include interferences from fences and power lines. Also, a relatively large contrast between the electrical conductivity of the contaminants and the geologic materials is needed for the detection of the contaminants by EM instruments. 

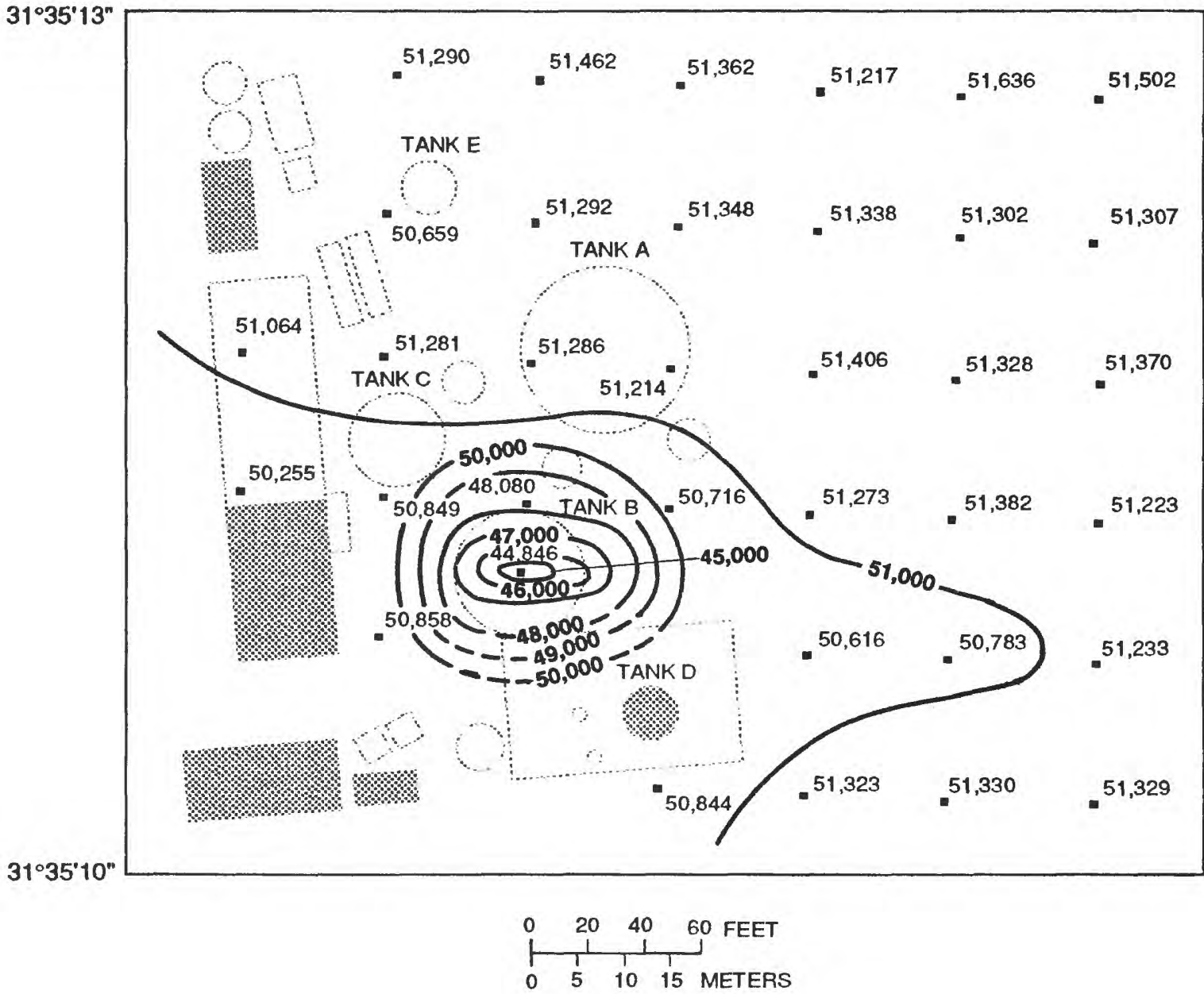

EXPLANATION

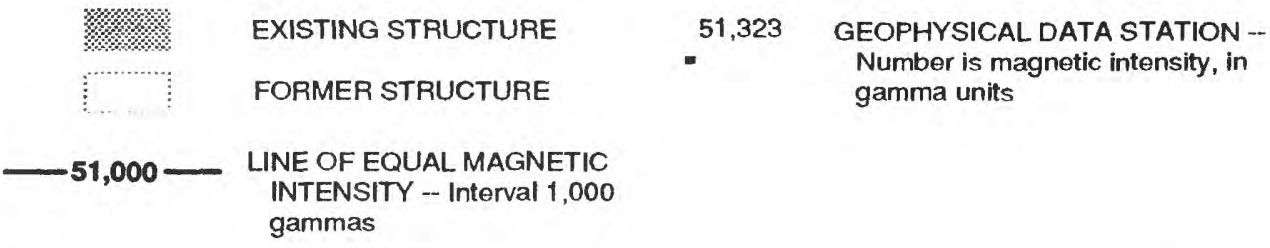

Figure 14.--Results of a magnetometer survey showing a negative anomaly centered over a buried tank.

Apparent conductivity readings were recorded at the geophysical data stations (fig. 9). Both vertical and horizontal coil readings were recorded at 10 - and $20-\mathrm{m}$ coil spacings by the instrument. The relative depth of penetration increases with increasing distance of coil separation; however, the true depth of penetration depends on many subsurface factors, such as the presence of conductive clay layers, depth to ground water, and the presence of metallic objects. Conductive targets reduce the depth of penetration and can mask materials beneath them. Ground water also increases the conductivity of subsurface materials. The depth of penetration most likely varied throughout the study area. 
Saunders and Cox (1987) successfully used EM conductivity surveys to delineate relatively thick areas of hydrocarbon accumulation (metal free), which is indicated by very low apparent conductivity readings. There was no evidence of hydrocarbon detection by EM in the study area. Hydrocarbons apparently were not recognizable targets for the EM instruments because they were found to occur in "patches" or in relatively thin, discontinuous pools. Also, if present, the hydrocarbons may have been masked by surface interference, such as metallic debris and clayey fill material that could have interfered with EM conductivity readings.

The horizontal coil (vertical dipole) orientation of this instrument proved to be useful in locating areas of buried pipes (fig. 15). Metallic objects are represented by values greater than $700 \mathrm{mmhos} / \mathrm{m}$ (McNeill, 1983). Exploration trenching, which was conducted subsequent to the EM surveys, verified the presence of iron pipes in the vicinity of the high conductivity values. The orientation of these buried pipes seems to coincide roughly with the alignment of the high field readings in the EM conductivity surveys.
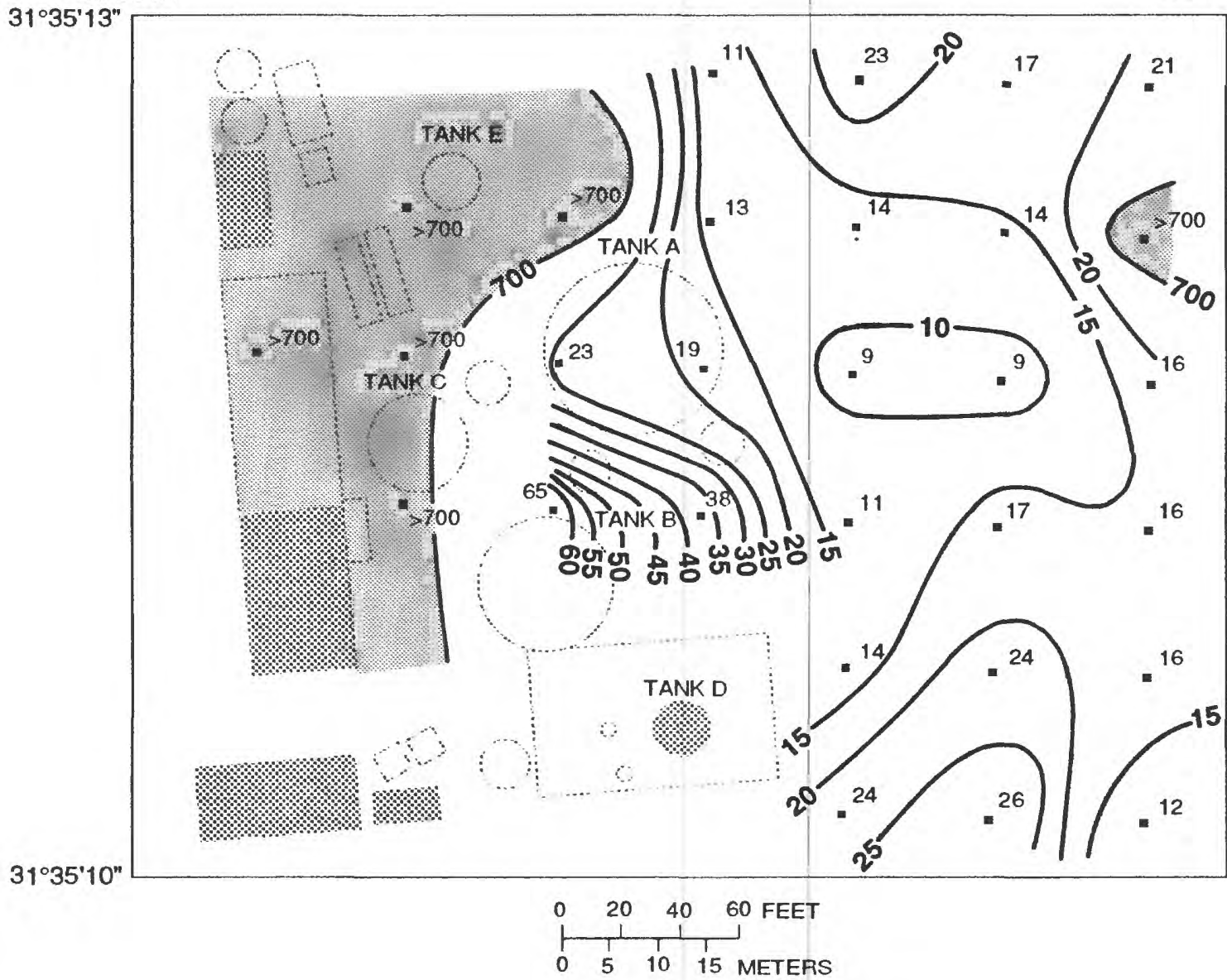

EXPLANATION

\section{EXISTING STRUCTURE}

FORMER STRUCTURE

AREAS OF HIGH APPARENT

CONDUCTIVITY -- Shows zones of metallic pipes or debris

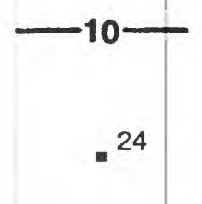

LINE OF EQUAL APPARENT CONDUCTIVITY -- Interval 5 millimhos per meter GEOPHYSICAL DATA STATION Number is apparent conductivity, in millimhos per meter

Figure 15.--Apparent conductivity survey; 20-meter horizontal coils. 
During a subsequent EM survey, the horizontal coil (vertical dipole) orientation also detected buried tank B (fig. 2), which had been delineated by the magnetometer survey (fig. 14). The apparent conductivity, which ranged from 53 to $65 \mathrm{mmhos} / \mathrm{m}$, normally would not be considered high enough for such a large metallic target (48 $\mathrm{ft}$ in diameter). However, the presence of conductive clayey fill material above the tank bottom most likely served to mask the tank by attracting most of the signal. Clay layers are conductive owing to their relatively high cation-exchange capacity. The flow of current is facilitated by the mobility of surface charges on the clay particles (McNeill, 1980). Magnetometer data were not affected by the clayey fill.

Apparent conductivity readings that ranged from about 15 to $30 \mathrm{mmhos} / \mathrm{m}$ throughout most of the study area generally were representative of a subsurface clay layer. Exploratory borings (Supplemental Data) confirmed the continuity of this clay layer. Prior to the installation of wells HS-9, $-10,-11$, and -12 , however, EM conductivity data indicated the possible absence of clay in the southeastern part of the study area. In that area, EM conductivity was lower (less than $15 \mathrm{mmhos} / \mathrm{m}$ ) than that recorded in the areas where a conductive subsurface clay layer was present (fig. 15). In other parts of the area, lower conductivities were confirmed as being non-representative of natural conditions. In those areas, concrete and various other non-metallic debris affected the readings. The geologic log of well HS-9, which was drilled in an area of low EM conductivity, confirmed the absence of the clay layer in the southeastern part of the study area (fig. 10).

\section{Electrical Resistivity}

Vertical electrical resistivity sounding (VES) techniques may provide information on subsurface geologic materials, buried objects, and contaminant plumes. Where electrical contrasts occur, depths to boundaries, geologic or man-made, may be estimated from VES data. Electrical current is directly injected into the ground using metal electrodes. The difference or drop in voltage across two electrodes is recorded in the field. Apparent electrical resistivity then may be calculated using an equation based on the electrode arrangement and the distances between electrodes. (As with the EM conductivity method, a large electrical contrast in subsurface materials is needed to obtain useful results with the resistivity method.) Limitations include interference from metal objects on the surface and in the subsurface, the inability to conduct current due to the lack of moisture or frozen conditions in near-surface materials, and the presence of clay in the near-surface, which reduces depth of penetration. Five VES surveys were conducted in the study (fig. 16). The basic Wenner electrode configuration of the Bison Offset Sounding System, was used in all the VES surveys. Two of the five possible electrode configurations are shown in figure 17 (Lacombe and others, 1986).

The deeper (larger) electrode spacings in soundings VES-1, VES-3 (E-W), VES-4, and VES-5 also provided geologic information. The decrease in apparent resistivity values at larger electrode spacings (Aspacings) represents the electrically-conductive upper clay layer (figs. 10 and 18). Drilling information has shown this clay layer to be present throughout most of the study area (with the exception of the southeastern part). The delineation of the clay layer is important because it could serve as a restricting layer that may impede vertical ground-water flow.

The east-west apparent resistivity curve for VES-1 increases significantly at the deepest electrodespacing depth (fig. 18). (The term "spacing depth" is used because relative depths of penetration are dependent on many subsurface factors, and thus, may vary across the study area.) This increase in apparent resistivity reflects sounding penetration into the Ocala Limestone, which is the highly resistive bedrock underlying the unconsolidated sediments. 


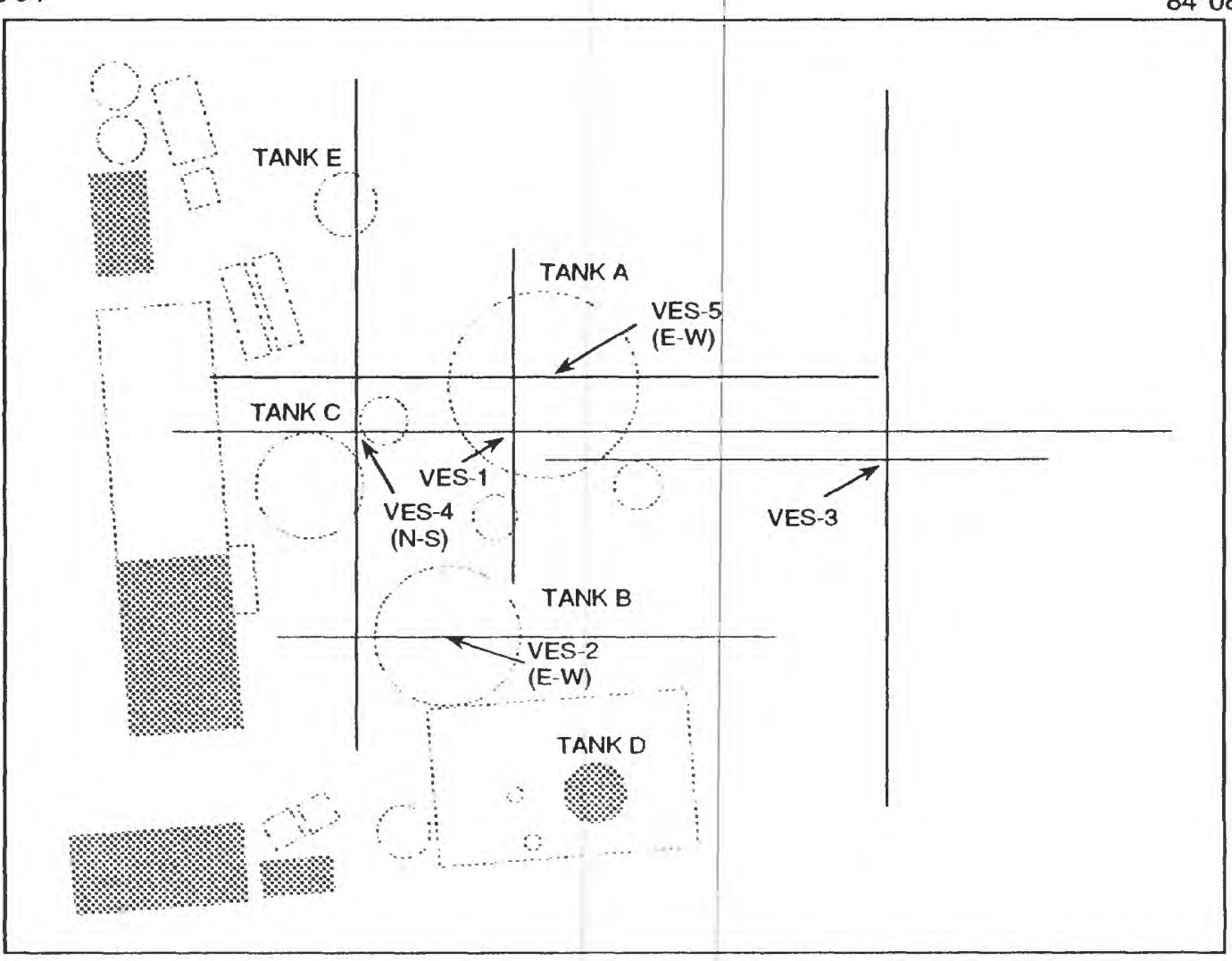

$$
\begin{array}{lllll}
0 & 20 & 40 & 60 & \text { FEET } \\
\mid & 1 & 1 & 1 \\
0 & 5 & 10 & 15 & \text { METERS }
\end{array}
$$

\section{EXPLANATION}

\section{EXISTING STRUCTURE}

FORMER STRUCTURE

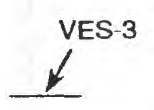

LINE OF RESISTIVITY SOUNDING AND IDENTIFICATION NUMBER -

Arrow indicates center of sounding

Note: Identification number indicates both north-south and east-west directions unless otherwise labelled as N-S or E-W.

Figure 16.--Locations of resistivity sounding surveys. 


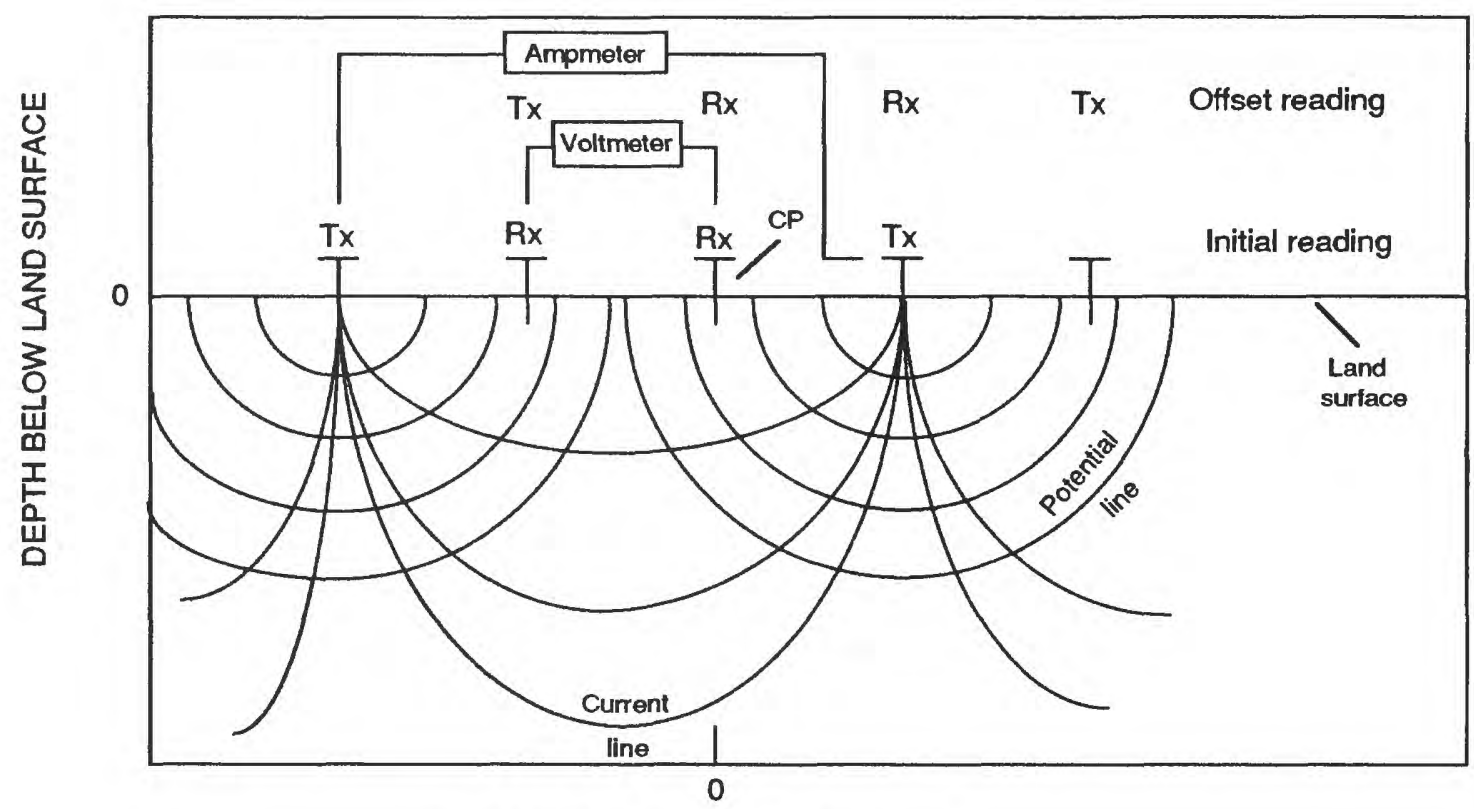

DISTANCE FROM CENTER POINT, CP

\section{EXPLANATION}

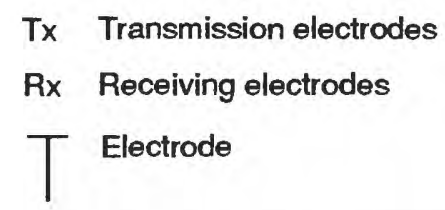

Figure 17.--Two of the five possible electrode configurations used in the offset Wenner resistivity sounding technique (Lacombe and others, 1986).

Electrical resistivity methods also were used to identify an anomaly associated with buried tank B (fig. 16). The apparent resistivity curve for VES-2 shows a sharp decrease in apparent resistivity beginning at the 1-m spacing depth (fig. 18). The sharp decrease in the curve is attributed to a large conductive object, which is the iron tank (tank B). Because most of the injected current was consumed by or attracted to the iron tank, no information could be obtained on geologic materials underlying this sounding location.

\section{Ground-Penetrating Radar}

Ground-penetrating radar (GPR) is a high-frequency electromagnetic geophysical method that has successfully been used in other investigations to locate buried drums, pipes, and trenches, and map the water-table, clay layers, and contaminants in the subsurface. The GPR instrument is sensitive to changes in the conductivity and the dielectric properties of subsurface materials. (Dielectric properties are a function of electrical polarization, which is affected by the composition and moisture content of subsurface materials (Keller and Frischknecht, 1982; Benson and others, 1983)). A vertical section produced from radar-wave reflections of the subsurface is printed out from the instrument, showing various degrees of contrast due to changes in conductivity and/or dielectric constant. Limitations to the GPR method include the complexity of the data obtained and the difficulty in interpreting the data. Power lines also can interfere with the GPR signal. 


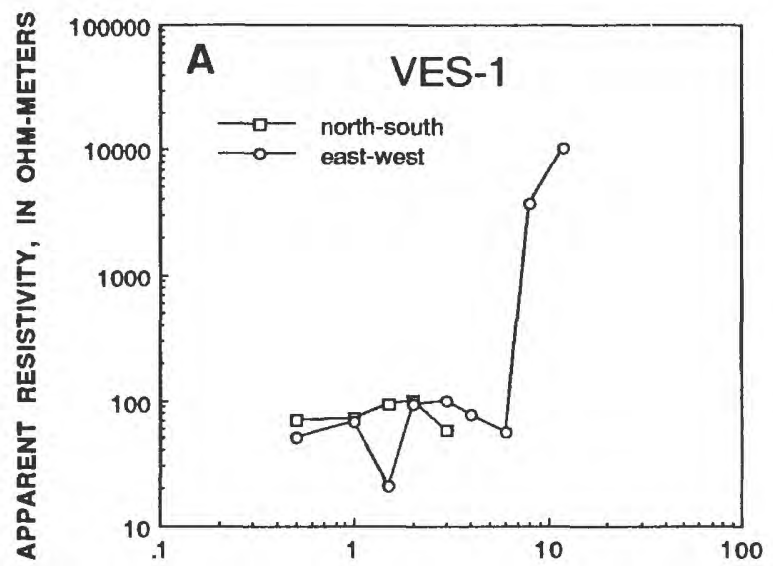

ELECTRODE SPACING (A-SPACING), IN METERS

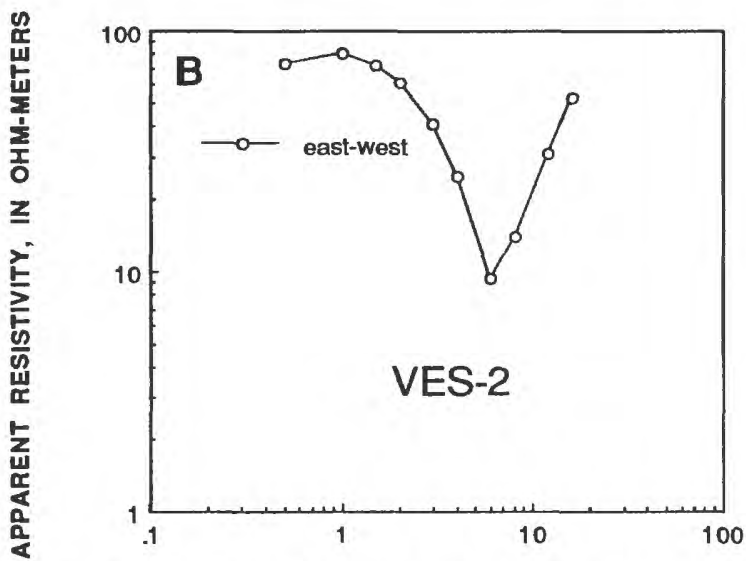

ELECTRODE SPACING (A-SPACING), IN METERS

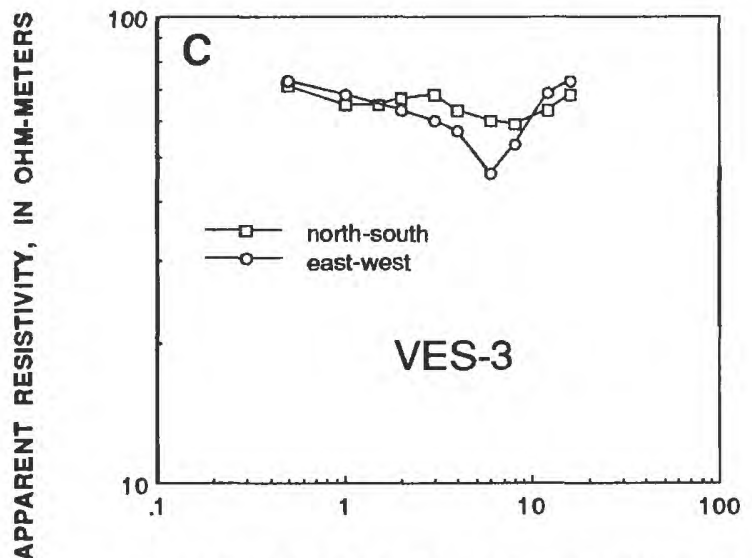

ELECTRODE SPACING (A-SPACING), IN METERS

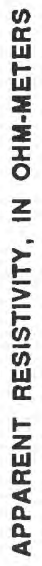

1000 D VES-4

- - east-west

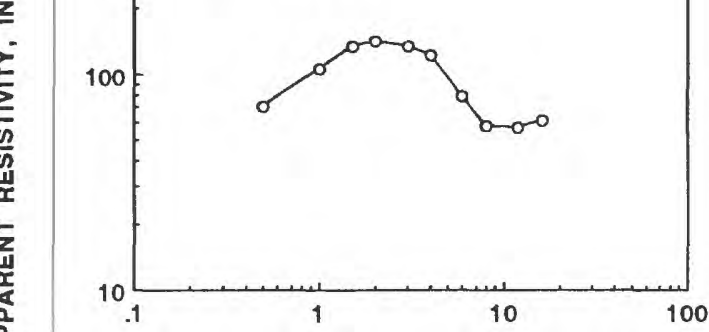

ELECTRODE SPACING (A-SPACING), IN METERS

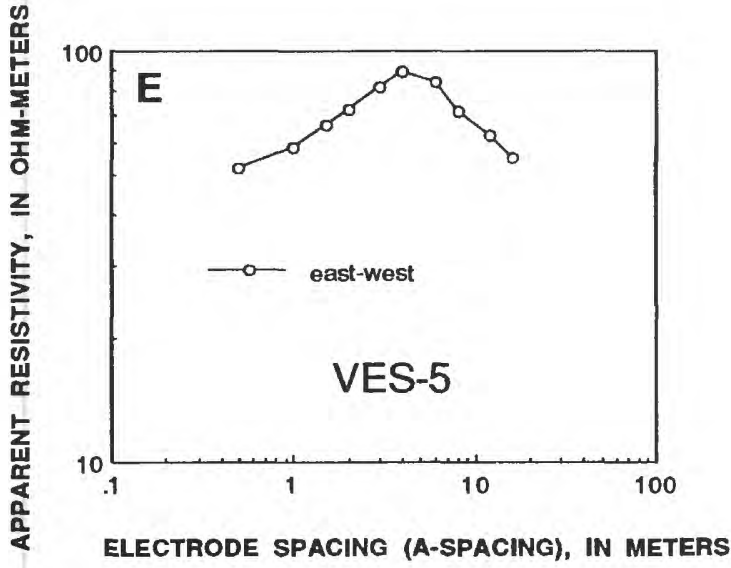

Figure 18.--Apparent resistivity sounding curves (see figure 16 for sounding locations). 
A GPR survey was conducted along and parallel to the geophysical data stations (fig. 19). Thirteen north-south lines and eleven east-west lines were run. Because most of the ground surface has been disturbed, the resulting radar signal was discontinuous and separated. However, a definite break in the depth of the radar reflection was prominent in many of the surveyed sections as illustrated in figure 20. These breaks in the depth of reflection represent in plain view the general area where the gas holding tanks had been located (fig. 19). In this area, large volumes of sand were used to fill surface irregularities during the decommissioning of the former gas plant. Dry sand has both a low dielectric constant (4 to 6), and a low conductivity $(0.0001$ to $1.0000 \mathrm{mmhos} / \mathrm{m})$; therefore, it would not cause a reflection in the radar section unless it were saturated. Fresh water has a high dielectric constant of 81 ; thus, saturated sand could produce a radar reflection (Benson and others, 1983). The sand fill or upper sand layer in the area generally was unsaturated. The radar most likely delineated areas where sand fill was used, which encompasses most of the area where the tanks were formerly located.

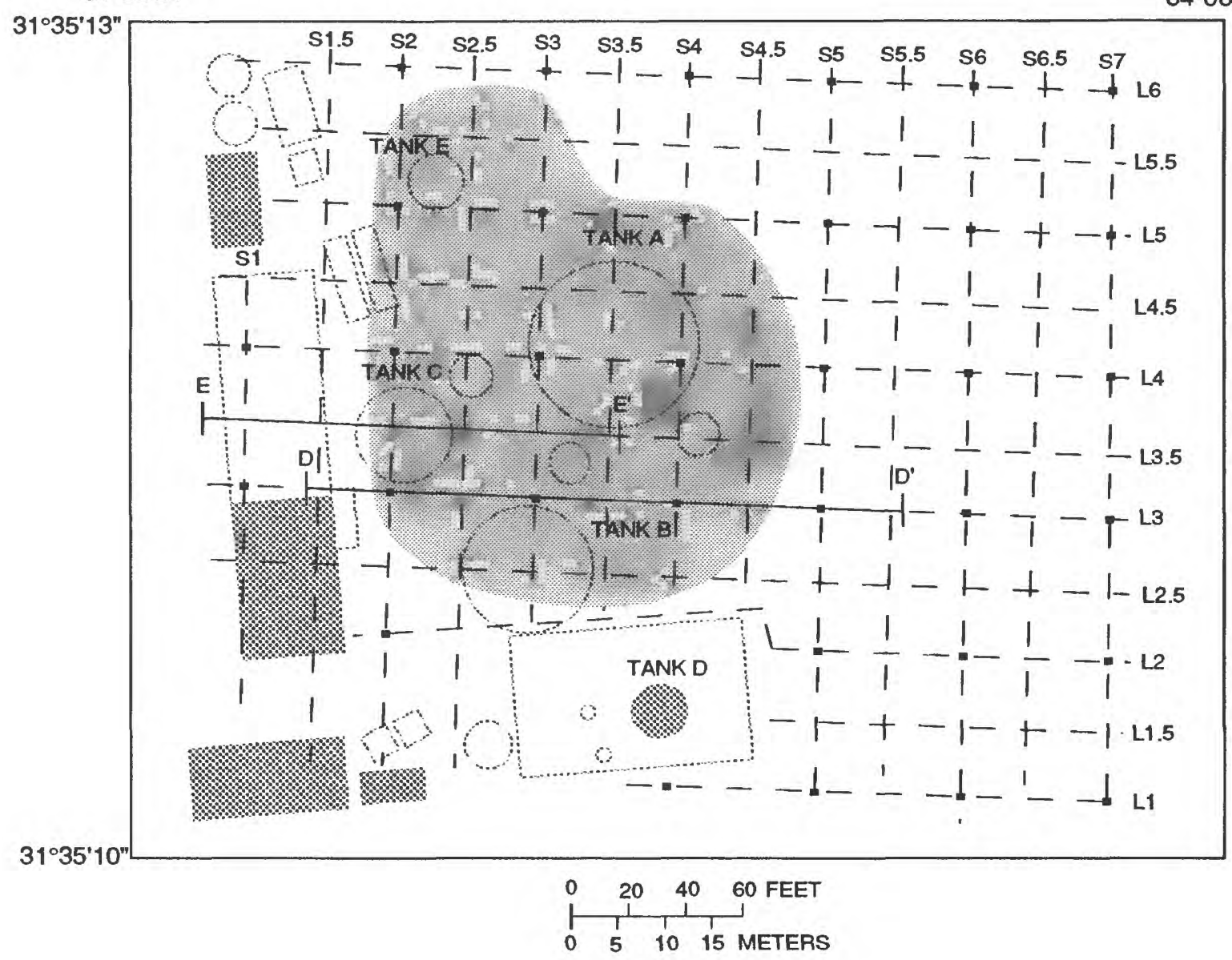

\section{EXPLANATION}
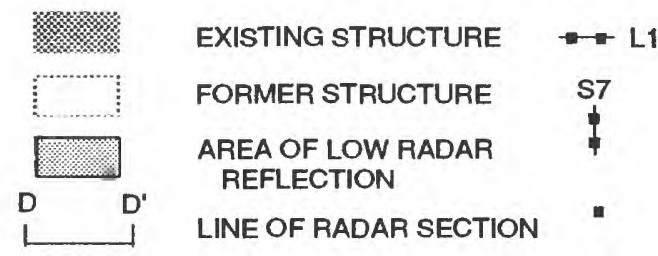

EAST-WEST SURVEY LINE

NORTH-SOUTH SURVEY LINE

GEOPHYSICAL DATA

STATION

Figure 19.--Ground-penetrating radar survey lines and outline of the area of low radar reflection. 


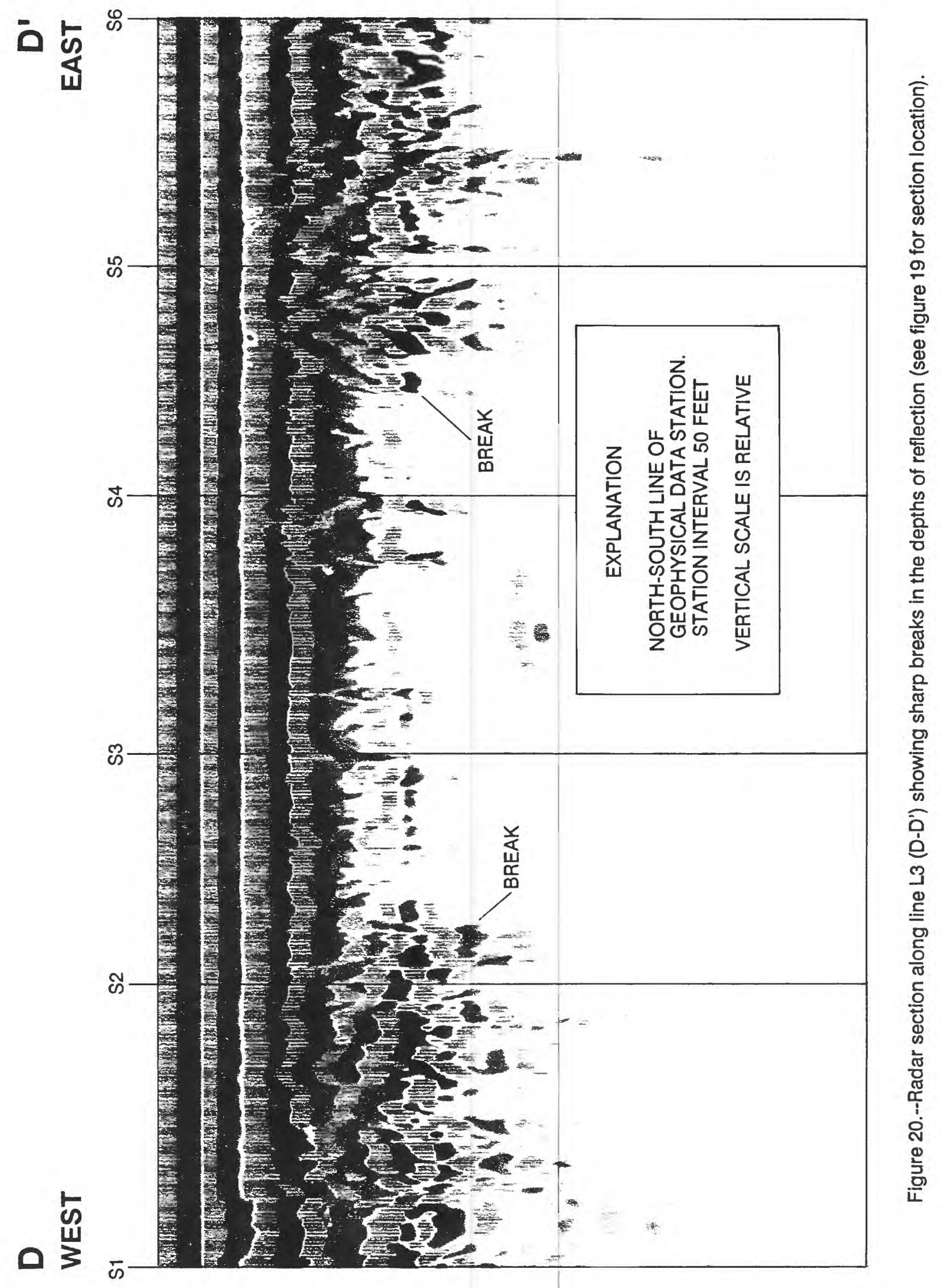


Radar also detected pipes or pieces of pipe that were scattered across the area (fig. 21), although no continuous pipes could be delineated from the radar sections. Figure 21 shows strong "echoes" in the radar signal produced by iron pipes at a depth of about 2.8 to $3.2 \mathrm{ft}$ below land surface. During trenching exploration, several pipes were discovered in this area. These pipes were oriented both north-south and east-west, and were about 4 in. in diameter. The pipes also were detected during the EM conductivity survey.

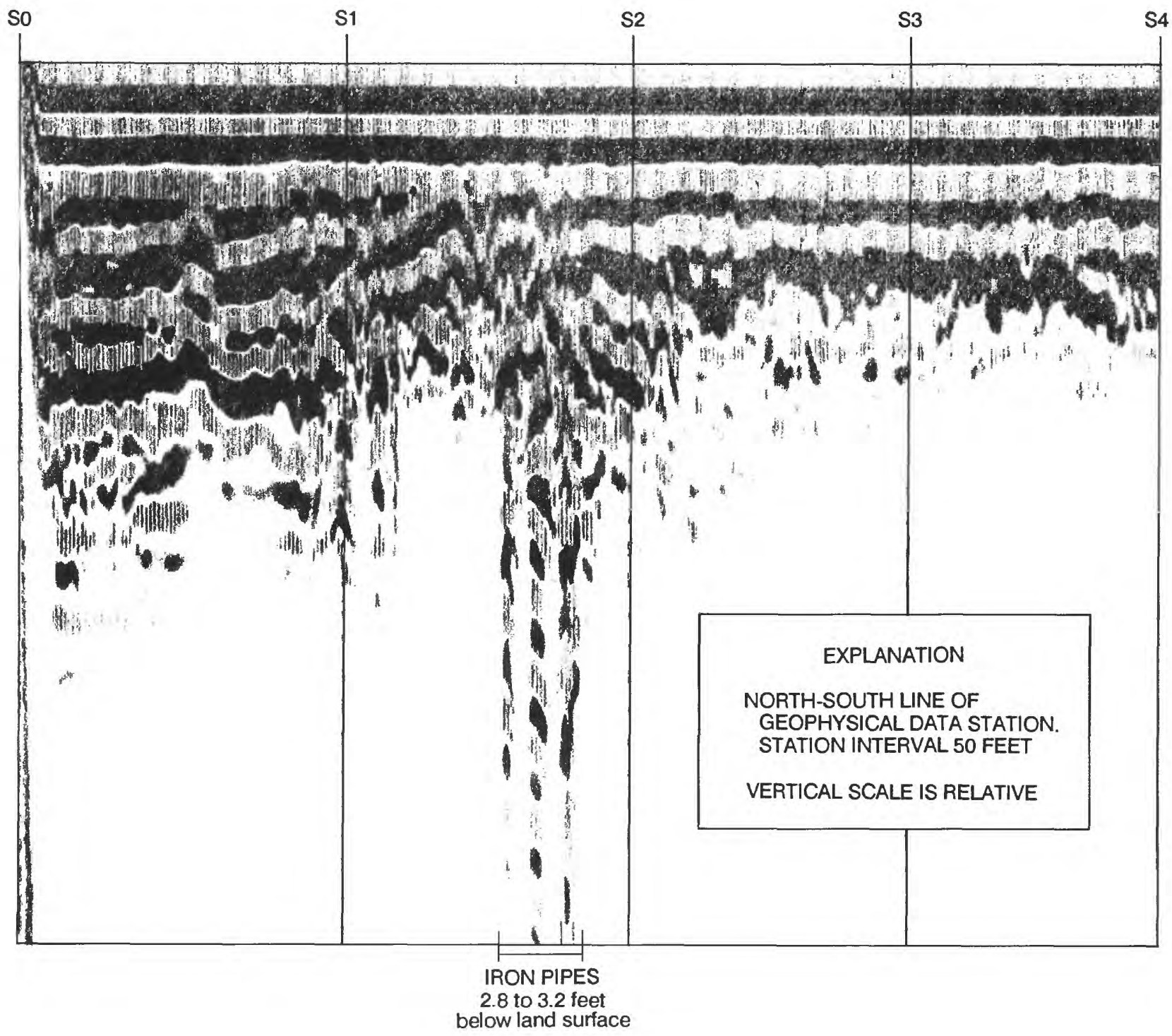

Figure 21.--Radar section along line L3.5 (E-E') showing strong "echoes" in the vicinity of know iron pipes (see figure 19 for section location). 


\section{EVALUATION OF CONTAMINATION}

\section{Extent of Hydrocarbon-Stained Materials}

Hydrocarbon-stained (black) material is present in the vicinity of the former gas plant, and it occurs in a wide variety of forms. Both fill and unconsolidated sediment layers have been affected by this staining (fig. 10 and Supplemental Data). The depths to stained layers range from 1 to $8 \mathrm{ft}$ below land surface, and the thickness of stained sediments ranges from 1 to $11.5 \mathrm{ft}$. A layer of dry, ashy material was prevalent in much of the area near the gas holding tanks, and randomly scattered in other parts of the study area. In the center of the area formerly occupied by tank A (wells B-5 and HS-3) (figs. 2 and 9), saturated, stained material was concentrated and had a strong hydrocarbon odor; strong odors generally correspond to Organic Vapor Analyzer (OVA) or HNU readings greater than 50 parts per million (ppm) in a volume of air (table 3). (These instruments were calibrated using quantifiable concentrations of methane and isobutylene in air, respectively.) Saturated stained material was found at well HS-12. The most vertically extensive staining was detected at boring HS-8, where all subsurface material (fill and unconsolidated sediments) from a depth of $2.5 \mathrm{ft}$ to the top of the Ocala Limestone at $14 \mathrm{ft}$, was stained. Extremely strong hydrocarbon odors (OVA readings greater than $1,000 \mathrm{ppm}$ ) were present in this borehole and in sediment samples that were retrieved from boring HS-8.

Most of the hydrocarbon staining occurs above the upper clay layer. However, some staining was observed below the upper boundary of this clay layer, along fractures in the clay, and in the matrix of the clay. Although the sandy nature of most of the clay samples suggests that the clay is somewhat permeable, most of the hydrocarbon staining was confined to the upper 0.5 to $1 \mathrm{ft}$ of the clay layer. However, in boring HS-8, the entire thickness of the clay layer was thoroughly stained by hydrocarbons.

Various intensities of hydrocarbon odors were detected from the subsurface during drilling and trenching operations. The locations and depths at which the odors were noted are given in table 3.

\section{Preliminary Analyses of Sediment, Waste, and Ground Water}

The major categories of waste typically associated with manufactured gas plants are tar and oil residues and sludges, spent oxide waste, and ash materials (Edison Electric Institute, 1984). Most of the contamination found in the unconsolidated sediments in the study area seems to be derived from tar and oil residues; no spent oxide waste was found. A relatively thin layer of ash, generally less than 6 in. thick, is present throughout much of the area. The emphasis of work performed to date has been on the analysis of tar and oil residues and associated organic contaminants in the unconsolidated sediments. 
Table 3.--Volatile-phase hydrocarbons detected in boreholes during drilling operations

[HNU, HNU Systems, Inc.; OVA, Century Organic Vapor Analyzer; ppm, parts per million; degree of intensity is a subjective evaluation of odor during drilling;

,-- no data; >, greater than]

\begin{tabular}{|c|c|c|c|c|}
\hline $\begin{array}{l}\text { Well/ } \\
\text { boring } \\
\text { number }\end{array}$ & $\begin{array}{l}\text { Sampling } \\
\text { interval } \\
\text { (feet) }\end{array}$ & $\begin{array}{l}\text { Type of } \\
\text { material }\end{array}$ & $\begin{array}{l}\text { HNU or OVA } \\
\text { reading(s) } \\
\quad(p p m)\end{array}$ & $\begin{array}{l}\text { Degree of } \\
\text { intensity } \\
\text { of odor }\end{array}$ \\
\hline B-3 & $1.0-2.0$ & $\begin{array}{l}\text { dry, blocky, } \\
\text { stained fill }\end{array}$ & 30,50 & moderate \\
\hline B-5 & $8.0-10.0$ & $\begin{array}{l}\text { hydrocarbon- } \\
\text { saturated, } \\
\text { loamy sand }\end{array}$ & $\begin{array}{r}70 \\
>1,000\end{array}$ & $\begin{array}{l}\text { strong } \\
\text { very strong } \\
\text { (when cased) }\end{array}$ \\
\hline B-6 & $4.0-6.0$ & $\begin{array}{l}\text { hydrocarbon- } \\
\text { saturated } \\
\text { clayey sand }\end{array}$ & 3.0 & weak \\
\hline B-7 & $4.0-6.0$ & clay & --- & weak \\
\hline B-16 & 3.5 & sandy clay & 8.5 & moderate \\
\hline B-20 & $2.5-7.0$ & clay & --- & moderate \\
\hline B-21 & $5.5-7.5$ & clay & --- & strong \\
\hline HS-2 & $\begin{array}{r}3.0-4.5 \\
18.0-22.5\end{array}$ & $\begin{array}{l}\text { silty sand } \\
\text { coarse sand }\end{array}$ & $\begin{array}{r}300 \\
>1,000\end{array}$ & $\begin{array}{l}\text { strong } \\
\text { strong }\end{array}$ \\
\hline HS-3 & $6.5-8.0$ & sand & --- & strong \\
\hline HS-8 & $2.5-14.0$ & $\begin{array}{l}\text { loamy sand and } \\
\text { gravelly, clay fill, } \\
\text { sandy clay, clayey silt }\end{array}$ & $>1,000$ & very strong \\
\hline HS-10 & $4.5-6.0$ & $\begin{array}{l}\text { dry, ashy } \\
\text { hydrocarbon- } \\
\text { stained sandy } \\
\text { silt }\end{array}$ & -- & weak \\
\hline HS-11 & $2.0-5.5$ & $\begin{array}{l}\text { gravelly, clay } \\
\text { fill }\end{array}$ & --- & weak \\
\hline HS-12 & 5.5- 9.5 & silty sand, clay & --- & moderate \\
\hline
\end{tabular}


Organic compounds detected in the unconsolidated sediments in the study area are present in four phases: the hydrocarbon fluid phase, the hydrocarbon solid phase, the aqueous phase, and the volatile phase. The hydrocarbon fluid phase is a liquid mixture of hydrocarbon compounds, immiscible with water, that forms a fluid phase physically distinct from the aqueous phase. Tar residues are significantly denser and more viscous than hydrocarbons in the aqueous phase, whereas oils are less dense and less viscous. The hydrocarbon solid phase consists of hydrocarbon compounds absorbed onto the matrix of the porous medium (unconsolidated sediments). The aqueous phase consists of the hydrocarbons in solution in water in the saturated or unsaturated zone. The volatile phase consists of hydrocarbon gases trapped in ground water or in unsaturated sediments. The aqueous and the volatile phases are the most mobile in the subsurface (Hult and Schoenburg, 1984; Gas Research Institute, 1987).

\section{Sediment and Waste}

Unconsolidated sediment samples and hydrocarbon waste samples were chemically analyzed to characterize contamination in the study area. Total organic carbon (TOC), specific organic compounds, metals, and cyanide were used as indicator constituents for contamination. Sampling depths ranged from near-surface to the top of the Ocala Limestone.

\section{Total Organic Carbon}

Total organic carbon can be used as a gross indicator of the degree of organic contamination associated with petroleum products or coal tars (Spruill, 1988; Hult and Schoenberg, 1984). High TOC concentrations commmonly indicate organic contamination. Low TOC concentrations, however, do not prove necessarily that organic contamination is absent; they merely suggest that contamination, if present, probably will be at a relatively low level. In general, in the Southeastern United States, a TOC concentration in sediments of 1.0 percent by weight or higher at depths greater than $1.0 \mathrm{ft}$ (Perkins, 1987) is considered significant, indicating possible contamination.

Sediment samples collected from boring HS-4 (fig. 9), which is considered to be areally removed from former gas plant activities, had a TOC concentration of 0.1 percent at depths of 10.0 to $10.5 \mathrm{ft}$ and 14 $\mathrm{ft}$. Samples collected from boring HS-8, located in an area of high organic contamination, had TOC values of 4.4 and 1.8 percent at 4.0 to $4.5 \mathrm{ft}$ and $14.0 \mathrm{ft}$, respectively. The distribution of TOC with depth at selected borings and wells is shown in figures 22-24. TOC concentrations found in sediment samples are given in table 4.

At most well or boring sites the general vertical distribution of TOC concentrations indicated that TOC decreased with depth. TOC concentrations typically showed marked decreases (from greater than 4 percent to 0.1 percent) below depths of 5 to $10 \mathrm{ft}$, in the upper clay layer (figs. 22-24). An exception was at boring HS-8, where at a depth of $14 \mathrm{ft}$ at the top of the Ocala Limestone, the TOC concentration was 1.8 percent. Well HS-3, located in an area of known contamination, also had a high TOC concentration of 10.9 percent at a depth of 7 to $8 \mathrm{ft}$ below land surface.

The results from the TOC analyses generally correspond with observed hydrocarbon staining in the unconsolidated sediments. Higher TOC concentrations detected in sediment samples collected at borings B-3 (2 ft) and HS-8 (14 ft), and wells HS-3 (7.0 to $8.0 \mathrm{ft}$ ) and HS-11 (3.5 to $4.0 \mathrm{ft}$ ) represent localized staining (table 4). (The sample collected from boring HS-5 consisted of coal ash and had a TOC concentration of 76.9 percent.) Overall, the horizontal distribution of TOC concentrations indicated a general decrease in TOC with an increase in the distance from the former gas plant. 


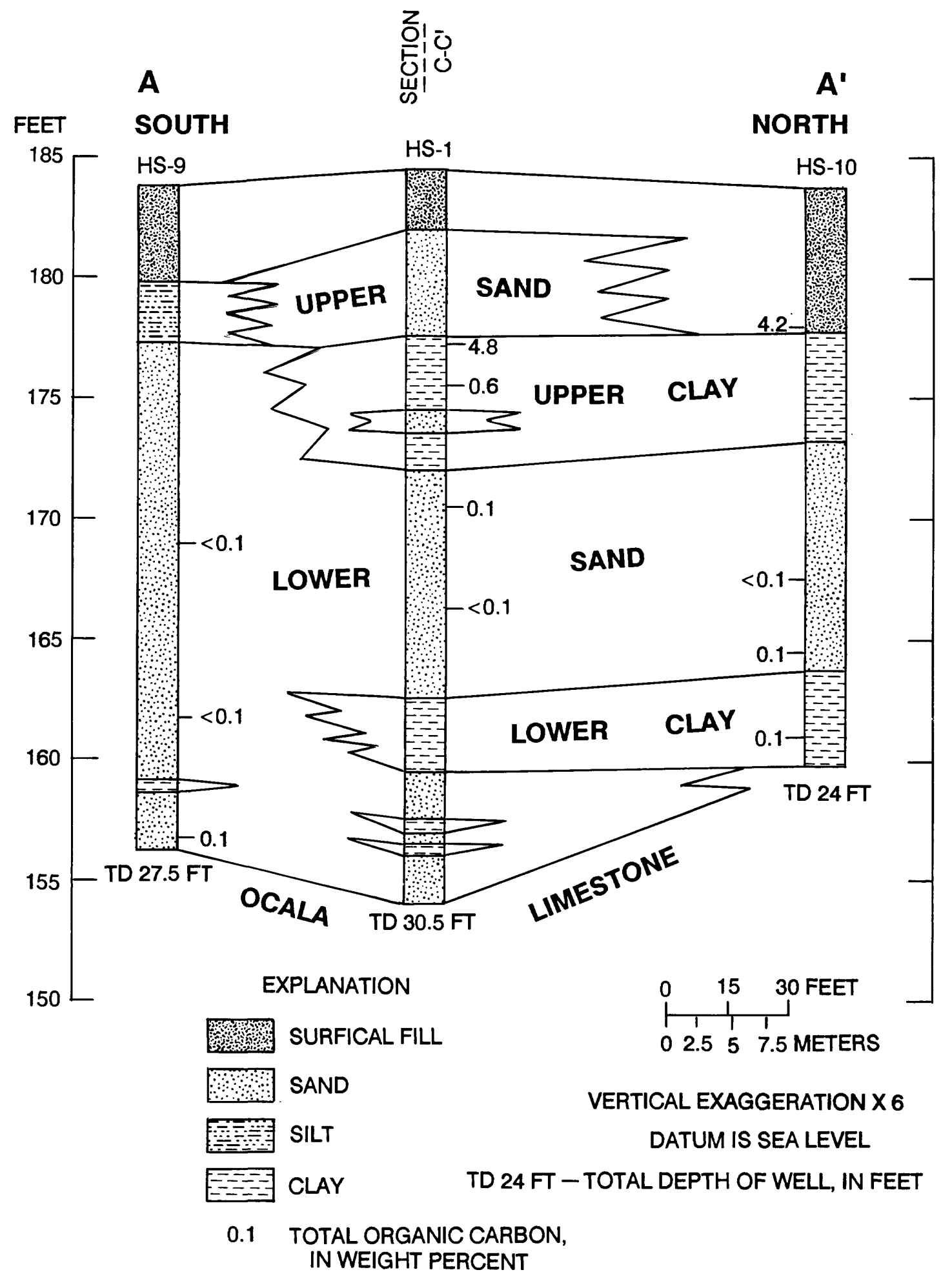

Figure 22.--Geologic section A-A' and distribution of total organic carbon at wells HS-9, HS-1, and HS-10 (see figure 9 for location of section line). 


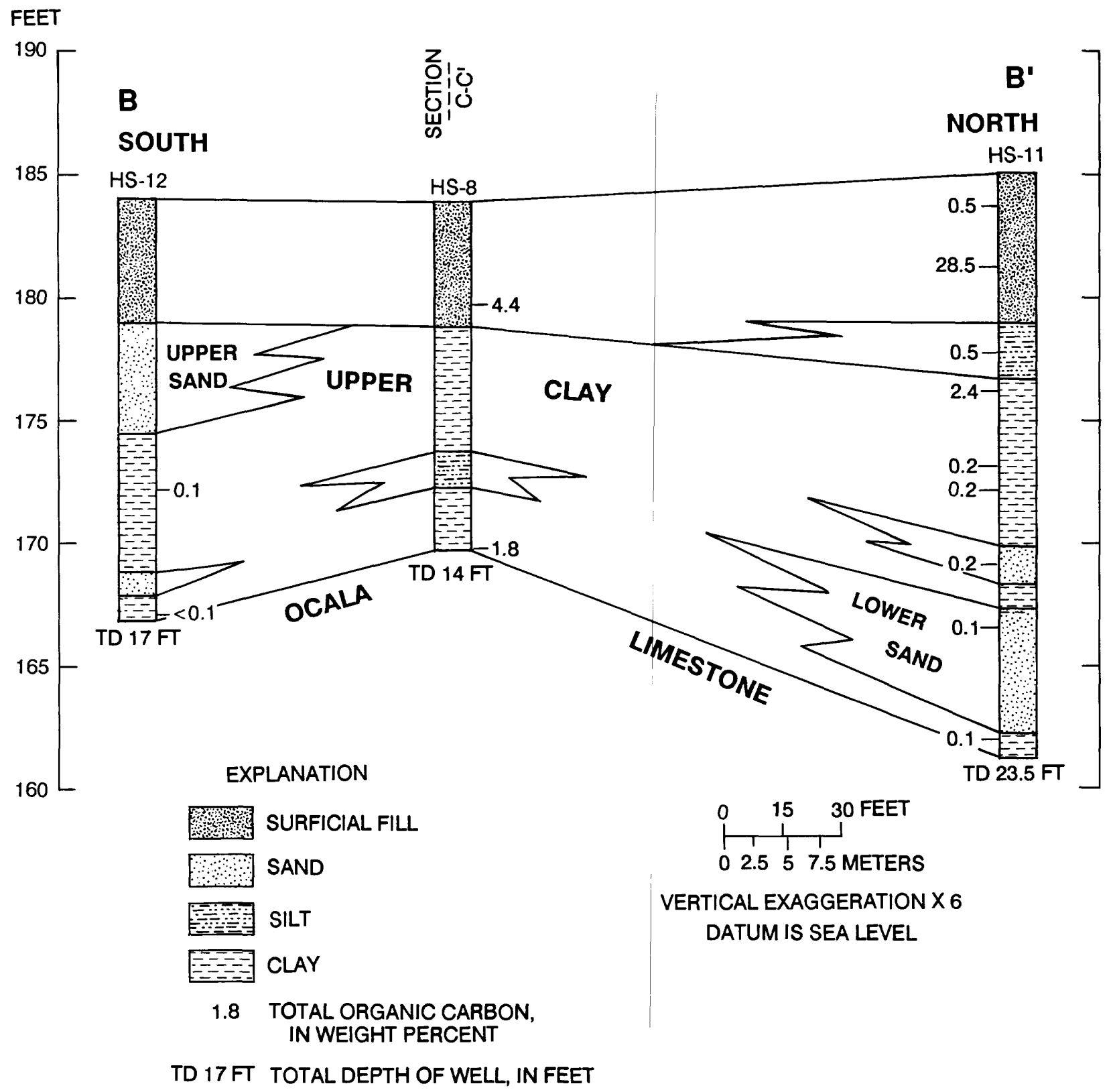

Figure 23..--Geologic section B-B' and distribution of total organic carbon at well HS-12, boring HS-8, and well HS-11 (see figure 9 for location of section line). 


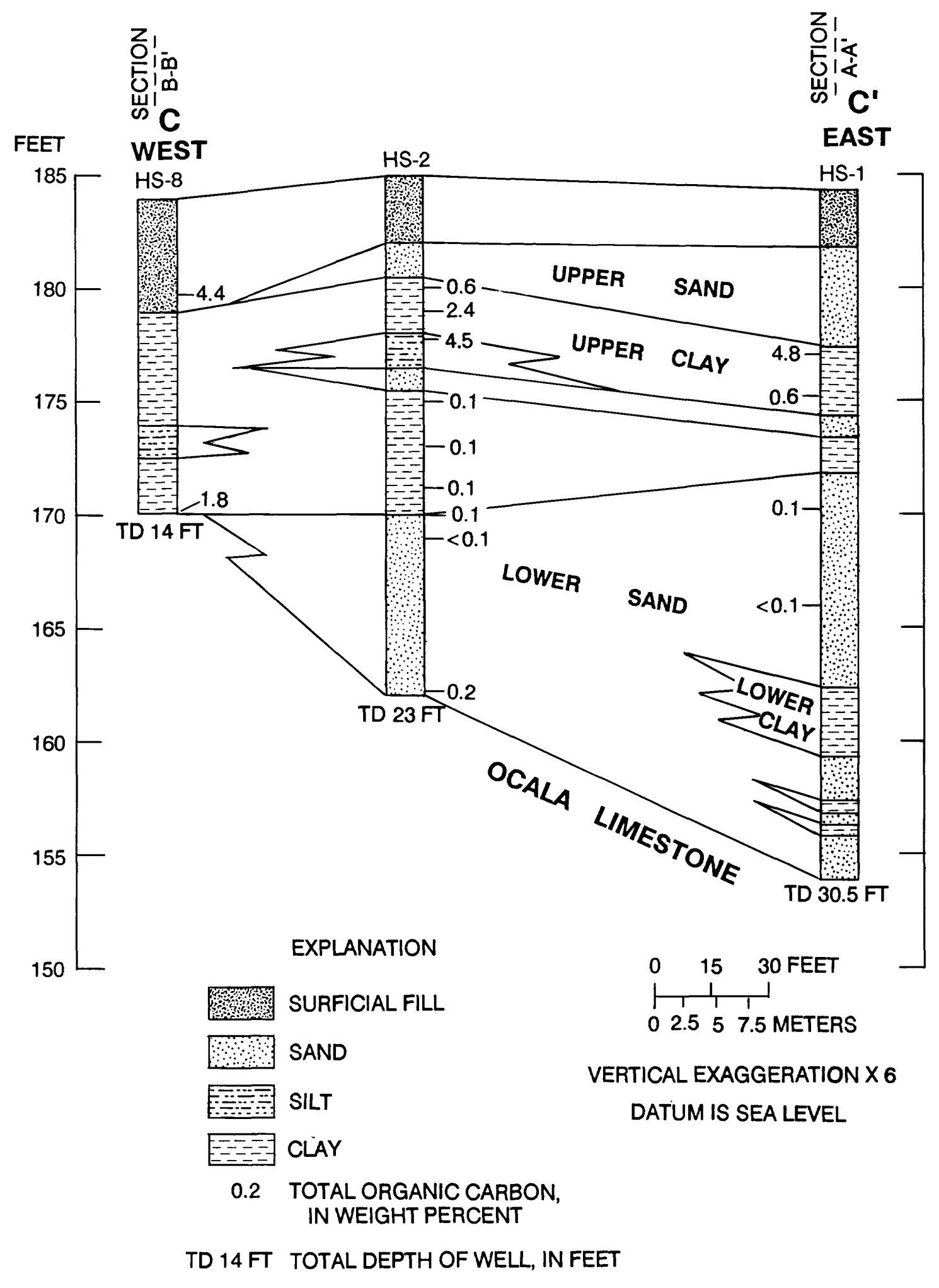

Figure 24.--Geologic section C-C' and distribution of total organic carbon at boring HS-8, and wells HS-2 and HS-1 (see figure 9 for location of section line). 
Table 4.-- Total organic carbon concentrations in sediments

[Total organic cargon concentrations are given in weight percent; <, less than]

\begin{tabular}{|c|c|c|c|}
\hline $\begin{array}{c}\text { Site } \\
\text { number }\end{array}$ & $\begin{array}{l}\text { Date } \\
\text { collected }\end{array}$ & $\begin{array}{l}\text { Depth } \\
\text { (feet) }\end{array}$ & $\begin{array}{c}\text { Total } \\
\text { organic } \\
\text { carbon }\end{array}$ \\
\hline B-3 & 03-07-89 & 2.0 & 20.6 \\
\hline B-4 & 03-07-89 & $\begin{array}{r}1.5 \\
5.0-8.0\end{array}$ & $\begin{array}{l}7.1 \\
7.2\end{array}$ \\
\hline B-5 & 03-07-89 & 7.0 & 6.1 \\
\hline B-6 & 03-07-89 & $\begin{array}{r}4.0-6.0 \\
8.0\end{array}$ & $\begin{array}{l}5.4 \\
0.1\end{array}$ \\
\hline B-7 & 03-07-89 & $4.0-6.0$ & 6.1 \\
\hline B-8 & 03-07-89 & $\begin{array}{l}3.0-4.0 \\
7.0-8.0\end{array}$ & $\begin{array}{r}1.1 \\
.1\end{array}$ \\
\hline B-15 & 03-08-89 & $\begin{array}{r}2.0 \\
5.0-5.5 \\
6.0\end{array}$ & $\begin{array}{r}.8 \\
.8 \\
5.0\end{array}$ \\
\hline HS-1 & 04-04-89 & $\begin{array}{r}7.0-7.5 \\
9.0 \\
14.0 \\
18.0-18.5\end{array}$ & $\begin{array}{r}4.8 \\
.6 \\
.1 \\
<.1\end{array}$ \\
\hline HS-2 & $04-04-89$ & $\begin{array}{r}5.0 \\
6.0 \\
7.0-7.5 \\
10.0 \\
12.0 \\
12.5-15.0 \\
15.0 \\
16.0 \\
22.5-23.0 \\
23.0\end{array}$ & $\begin{array}{r}.6 \\
2.4 \\
4.5 \\
.1 \\
.1 \\
.1 \\
.1 \\
<.1 \\
.2 \\
.2\end{array}$ \\
\hline HS-3 & 04-05-89 & $7.0-8.0$ & 10.9 \\
\hline $\mathrm{HS}-4$ & $04-05-89$ & $\begin{array}{r}10.0-10.5 \\
14.0\end{array}$ & $\begin{array}{l}.1 \\
.1\end{array}$ \\
\hline HS-5 & 04-05-89 & 2.0 & 76.9 \\
\hline
\end{tabular}


Table 4.-- Total organic carbon concentrations in sediments--Continued

[Total organic carbon concentrations are given in weight percent; <, less than]

\begin{tabular}{|c|c|c|c|}
\hline $\begin{array}{c}\text { Site } \\
\text { number }\end{array}$ & $\begin{array}{l}\text { Date } \\
\text { collected }\end{array}$ & $\begin{array}{l}\text { Depth } \\
\text { (feet) }\end{array}$ & $\begin{array}{l}\text { Total } \\
\text { organic } \\
\text { carbon }\end{array}$ \\
\hline HS-8 & $04-06-89$ & $\begin{array}{r}4.0-4.5 \\
14.0\end{array}$ & $\begin{array}{l}4.4 \\
1.8\end{array}$ \\
\hline HS-9 & $07-11-89$ & $\begin{array}{l}14.5-15.0 \\
21.5-22.5 \\
26.5-27.5\end{array}$ & $\begin{array}{r}<0.1 \\
<.1 \\
.1\end{array}$ \\
\hline HS-10 & $07-12-89$ & $\begin{array}{r}5.5-6.0 \\
16.0-16.5 \\
19.0-19.5 \\
22.5-23.0\end{array}$ & $\begin{array}{r}4.2 \\
<.1 \\
.1 \\
.1\end{array}$ \\
\hline HS-11 & $07-13-89$ & $\begin{array}{r}1.0-1.5 \\
3.5-4.0 \\
7.0-7.5 \\
8.5-9.0 \\
11.5-12.0 \\
12.5-13.0 \\
15.5-16.0 \\
18.0-18.5 \\
22.5-23.0\end{array}$ & $\begin{array}{r}.5 \\
28.5 \\
.5 \\
2.4 \\
.2 \\
.2 \\
.2 \\
.1 \\
.1\end{array}$ \\
\hline HS-12 & 07-13-89 & $\begin{array}{l}11.5-12.0 \\
16.5-17.0\end{array}$ & $\begin{array}{r}.1 \\
<.1\end{array}$ \\
\hline TP-4 & 05-03-89 & $2.0-4.0$ & 3.1 \\
\hline TP-6 & 05-03-89 & 4.0 & 5.7 \\
\hline
\end{tabular}

\section{Specific Organic Compounds}

Both sediment cores and hydrocarbon wastes were sampled and chemically analyzed to identify as many organic compounds as possible. However, because tar and oil residues have been shown to consist of a complex mixture of hundreds of organic compounds (Pereira and Rostad, 1986; Spruill, 1988), initial analyses targeted compounds found on the list of priority pollutants (EPA, 1989).

A sample of dense, organic liquid was collected from well B-5, which is near the center of the former area of tank A (figs. 2 and 9). The targeted organic compounds identified in this sample are listed in table 5. As is typical at other abandoned gas plants, many of the identified individual compounds are polycyclic aromatic hydrocarbons (PAH's) that contain two or more fused benzene rings. 
Table 5.-- Volatile and semivolatile organic-compound concentrations detected in a liquid hydrocarbon-waste sample from well B-5, April 21, 1989

$[(\mu g / L)$, micrograms per liter]

\begin{tabular}{|c|c|c|c|c|c|}
\hline $\begin{array}{c}\text { Volatile } \\
\text { organic } \\
\text { compounds }\end{array}$ & $\begin{array}{c}\text { Concentration } \\
\qquad(\mu \mathrm{g} / \mathrm{L})\end{array}$ & $\begin{array}{c}\text { Detection } \\
\text { level } \\
(\mu \mathrm{g} / \mathrm{L})\end{array}$ & $\begin{array}{l}\text { Semivolatile } \\
\text { organic } \\
\text { compounds }\end{array}$ & $\begin{array}{l}\text { Concentration } \\
\qquad(\mu \mathrm{g} / L)\end{array}$ & $\begin{array}{c}\text { Detection } \\
\text { level } \\
(\mu \mathrm{g} / \mathrm{L})\end{array}$ \\
\hline Naphthalene & 18,000 & 10 & Naphthalene & 7,200 & 5 \\
\hline Benzene & 17,000 & 10 & Acenaphthylene & 340 & 5 \\
\hline Ethylbenzene & 3,300 & 10 & Acenaphthene & 2,700 & 5 \\
\hline 1,3,5-Trimethylbenzene & 140 & 10 & Anthracene & 1,200 & 5 \\
\hline $1,2,4$-Trimethylbenzene & 300 & 10 & Benzo(k)fluoranthene & 710 & 10 \\
\hline Isopropylbenzene & 48 & 10 & Chrysene & 840 & 10 \\
\hline N-propylbenzene & 840 & 10 & Fluoranthene & 900 & 5 \\
\hline Toluene & 88 & 10 & Fluorene & 1,900 & 5 \\
\hline \multirow[t]{6}{*}{ Xylenes(total) } & 3,000 & 10 & Phenanthrene & 5,300 & 5 \\
\hline & & & Pyrene & 1,200 & 5 \\
\hline & & & Benz(a)anthracene & 950 & 10 \\
\hline & & & $\begin{array}{l}\text { Phenol } \\
\text { Bis(2-ethylhexyl) }\end{array}$ & 680 & 5 \\
\hline & & & phthalate & 37 & 5 \\
\hline & & & Di-n-butylphlalate & 27 & 5 \\
\hline
\end{tabular}

The most abundant organic compounds detected in the liquid hydrocarbon (waste) sample are napthalene $(18,000$ micrograms per liter $(\mu \mathrm{g} / \mathrm{L})$ volatile, and $7,200 \mu \mathrm{g} / \mathrm{L}$ semivolatile), various alkylated benzenes (maximum concentration of $17,000 \mu \mathrm{g} / \mathrm{L}$ volatile), and phenanthrene $(5,300 \mu \mathrm{g} / \mathrm{L}$ semivolatile). (Volatile organic compounds (VOC's) include compounds that can be extracted by purge and trap methodology and generally have higher vapor pressures than the semivolatile organic compounds (SVOC's). SVOC's generally are extracted with methylene chloride. Naphthalene is included in both SVOC's and VOC's.) Collectively these three organic compounds, naphthalene, benzene, and phenanthrene, constitute about 70 percent of the combined targeted volatile and semivolatile contaminant concentration.

Analytical results for VOC's in six sediment cores are given in table 6 . A sample collected at boring HS-4, which is located about $400 \mathrm{ft}$ northwest of the area near the former gas holding tanks (fig. 9), is considered to be a background sample representative of natural sediments; no contamination by VOC's was detected at this site. Similarly, none of the targeted volatiles were detected in the core taken from well HS-1, which is located about $200 \mathrm{ft}$ east of the location of the former holding tanks. 
Table 6.-- Volatile organic-compound concentrations in sediment cores [estimated detection level ranges from 10 to $20 \mu \mathrm{g} / \mathrm{kg}$; nd, none detected]

\begin{tabular}{|c|c|c|c|c|c|c|}
\hline \multirow[b]{2}{*}{$\begin{array}{l}\text { Volatile } \\
\text { organic } \\
\text { compound }\end{array}$} & \multicolumn{5}{|c|}{$\begin{array}{l}\text { Concentration, in micrograms per kilogram, at indicated } \\
\text { well or boring number; and depth, in feet }\end{array}$} & \multirow[b]{2}{*}{$\begin{array}{l}1 / H S-4 \\
(10 \text { feet })\end{array}$} \\
\hline & $\begin{array}{l}1 / \mathrm{HS}-5 \\
(1 \text { foot })\end{array}$ & $\begin{array}{l}2 / H S-8 \\
\text { (8 feet) }\end{array}$ & $\begin{array}{l}1 / \mathrm{HS}-3 \\
\text { (7 feet) }\end{array}$ & $\begin{array}{l}3 / \mathrm{HS}-2 \\
\text { (21 feet) }\end{array}$ & $\begin{array}{l}3 / \mathrm{HS}-1 \\
\text { (19 feet) }\end{array}$ & \\
\hline Naphthalene & 290 & 560,000 & 450,000 & 860 & nd & nd \\
\hline Benzene & 1,600 & 14,000 & 28,000 & 89 & nd & nd \\
\hline Ethylbenzene & 320 & 65,000 & 73,000 & 120 & nd & nd \\
\hline 1,2,4-Trimethylbenzene & 140 & 21,000 & 18,000 & 110 & nd & nd \\
\hline 1,3,5-Trimethylbenzene & 45 & 9,900 & 6,400 & 98 & nd & nd \\
\hline N-Propylbenzene & 21 & 940 & 860 & 90 & nd & nd \\
\hline N-Butylbenzene & 17 & 1,300 & nd & 270 & nd & nd \\
\hline Dimethylbenzene (total) & 630 & 61,000 & 41,000 & 160 & nd & nd \\
\hline Isopropylbenzene & 19 & 3,700 & 3,300 & 140 & nd & nd \\
\hline Toluene & 630 & 24,000 & 5,900 & 110 & nd & nd \\
\hline p-Isopropyltoluene & 33 & 3,400 & 1,600 & 190 & nd & nd \\
\hline Styrene & 68 & 1,500 & 1,200 & 59 & nd & nd \\
\hline$m$ and $p-x y l e n e$ & 430 & 40,000 & 33,000 & 110 & nd & nd \\
\hline o-xylene & 200 & 28,000 & 8,000 & 49 & nd & nd \\
\hline Tert-butylbenzene & nd & nd & nd & 33 & nd & nd \\
\hline Sec-butylbenzene & nd & nd & nd & 85 & nd & nd \\
\hline
\end{tabular}

$1 /$ Collected on 04-05-89.

2/Collected on 04-06-89.

3/Collected on 04-04-89.

The highest concentrations of volatile organics were detected in hydrocarbon-waste samples collected from well HS-3 and boring HS-8 located in the area of former tank A (fig. 10), at depths of 7 and 8 $\mathrm{ft}$, respectively (table 6$)$. The most abundant VOC's were napthalene $(560,000$ micrograms per kilogram $(\mu \mathrm{g} / \mathrm{kg}$ )), various alkylated benzenes (maximum concentration of $73,000 \mu \mathrm{g} / \mathrm{kg}$ ), total xylenes (collective concentration of $68,000 \mu \mathrm{g} / \mathrm{kg}$ ), and toluene $(24,000 \mu \mathrm{g} / \mathrm{kg})$; napthalene concentrations constituted 70 percent of the total volatiles detected. The higher concentrations of VOC's detected in samples collected from boring HS-8 and well HS-3 correlate with higher TOC concentrations.

Analysis of a core sample from well HS-2 at a depth of $21 \mathrm{ft}$ showed the presence of the same VOC's detected in sediment samples from well HS-3 and boring HS-8, but at much lower concentrations. (The same VOC's also were detected in a sample collected from boring HS-5; however, that sample consisted of coal ash.) These data indicate that the depth of contamination in the central part of the area near the former tanks extends at least to the top of the Ocala Limestone (at a depth of $23 \mathrm{ft}$ at well HS-2). 


\section{Cyanide}

Six unconsolidated sediment cores from borings $H S-4,-5$, and -8 and wells $H S-1,-2$, and -3 were analyzed for cyanide. Concentrations of cyanide in the sediment cores ranged from less than $200 \mu \mathrm{g} / \mathrm{kg}$ to $1,600 \mu \mathrm{g} / \mathrm{kg}$ (table 7). The highest concentrations of cyanide, $1,500 \mu \mathrm{g} / \mathrm{kg}$ and $1,600 \mu \mathrm{g} / \mathrm{kg}$, were collected from areas of known organic contamination, well HS-3 and boring HS-8, respectively.

Table 7.-- Cyanide concentrations in sediment cores

$[\mu g / k g$, migcrograms per kilogram; <,less than]

\begin{tabular}{|c|c|c|c|}
\hline $\begin{array}{c}\text { Well/ } \\
\text { boring } \\
\text { number }\end{array}$ & $\begin{array}{l}\text { Date } \\
\text { collected }\end{array}$ & $\begin{array}{l}\text { Depth } \\
\text { (feet) }\end{array}$ & $\begin{array}{c}\text { Concentration } \\
(\mu \mathrm{g} / \mathrm{kg})\end{array}$ \\
\hline HS-5 & 04-05-89 & 1 & $<400$ \\
\hline HS-1 & $04-04-89$ & 19 & $<200$ \\
\hline HS-4 & 04-05-89 & 10 & $<200$ \\
\hline HS-8 & $04-06-89$ & 8 & 1,600 \\
\hline HS-2 & 04-04-89 & 21 & $<200$ \\
\hline HS-3 & 04-05-89 & 7 & 1,500 \\
\hline
\end{tabular}

\section{Metals}

Sediment cores and trenching samples were analyzed for 14 metals (table 8). Most of the samples were collected from depths at or below the horizons that showed hydrocarbon staining. Results of analyses of two sediment samples collected from boring HS-4, areally removed from the former gas plant area, and nine other sediment samples are given in table 8. Except for lead, zinc, arsenic, antimony, selenium, and manganese, the concentrations of the metals generally were comparable to background levels. Maximum concentrations of lead (94 milligrams per kilogram $(\mathrm{mg} / \mathrm{kg})$ ), zinc $(500 \mathrm{mg} / \mathrm{kg}$ ), and arsenic $(19 \mathrm{mg} / \mathrm{kg}$ ) exceeded background levels by factors of four, seven, and six, respectively. Background levels also were exceeded by factors of eleven, four, and eleven for antimony (19 $\mathrm{mg} / \mathrm{kg}$ ), selenium $(0.9 \mathrm{mg} / \mathrm{kg})$, and manganese $(0.11 \mathrm{mg} / \mathrm{kg})$, respectively.

Insufficient data exists to determine statistically whether the higher metal concentrations are natural or whether they result from gas plant contamination, because the variability in these constitutents in native unconsolidated sediments and fill material has not been well established. However, it is noteworthy that many samples that had a TOC concentration greater than 1.0 percent, also had elevated levels of lead or zinc, or both, except for the coal ash sample collected from boring HS-5. At well HS-1, the vertical distribution of lead and zinc concentrations correlate with the distribution of TOC. The highest zinc concentration $(500 \mathrm{mg} / \mathrm{kg}$ ) was detected in a sediment sample (TP-4) collected at the location of the only known purifier (figs. 2 and 9), one of the areas most likely to show metals contamination (Edison Electric Institute, 1984, Gas Research Institute, 1987). 
[Results in milligrams per kilogram; Cu, copper; Pb, lead; Zn, zinc; Ni, nickel; Co, cobalt; Cd, cadmium; Cr, chromium; As, arsenic; Sb, antimony; Se, selenium; Fe, imon; Mn, manganese; Al, aluminum; Ti, titanium;

Site Depth

number (feet)

$\mathrm{Cu} \quad \mathrm{Pb}$

Zn Ni Co

Cd

$\mathrm{Cr}$ As S

$\mathrm{Sb}$ Se $\mathrm{Fe} \quad \mathrm{Mn}$

A $\quad$ Ti

\begin{tabular}{|c|c|c|c|c|c|c|c|c|c|c|c|c|c|c|c|}
\hline \multirow[t]{6}{*}{$1 / \mathrm{HS}-1$} & $7.0-7.5$ & 31 & 94 & 190 & 15 & 8 & 0.6 & 35 & 2.9 & 2.5 & 0.4 & 1.70 & 0.11 & 2.9 & 0.28 \\
\hline & * & 31 & 85 & 180 & 15 & 6 & .5 & 35 & 2.8 & 4.5 & .4 & 1.60 & .08 & 2.8 & .27 \\
\hline & 9.0 & 21 & 29 & 78 & 22 & 10 & $<.5$ & 66 & 4.1 & 0.4 & .6 & 4.00 & .04 & 11.2 & .59 \\
\hline & 14.0 & 5 & 2 & 38 & 5 & 6 & $<.5$ & 52 & 17.0 & .1 & .2 & 6.50 & .01 & 1.6 & .06 \\
\hline & $\star$ & 5 & 1 & 40 & 5 & 4 & $<.5$ & 38 & 19.0 & .1 & .2 & 7.30 & .01 & 1.6 & .06 \\
\hline & $18.0-18.5$ & 1 & 1 & 13 & 2 & 3 & $<.5$ & 10 & 1.0 & $<.1$ & .1 & 0.60 & $<.01$ & 0.7 & .04 \\
\hline $2 / \mathrm{HS}-3$ & $7.0-8.0$ & 23 & 73 & 47 & 6 & 2 & $<.5$ & 18 & 3.5 & 1.6 & .9 & .80 & .08 & 2.6 & .16 \\
\hline $2 / \mathrm{HS}-4$ & $10.0-10.5$ & 23 & 19 & 55 & 19 & 19 & $<.5$ & 55 & 3.3 & .3 & .1 & 3.00 & .01 & 9.0 & .46 \\
\hline & 14.0 & 16 & 22 & 67 & 24 & 19 & $<.5$ & 70 & 1.6 & .3 & .1 & 2.80 & .01 & 8.1 & .44 \\
\hline & $\star$ & 17 & 22 & 68 & 25 & 20 & $<.5$ & 69 & 1.7 & .4 & .2 & 2.80 & .01 & 8.1 & .44 \\
\hline \multirow[t]{2}{*}{ 2/HS-5 } & 2.0 & 5 & 2 & 8 & 2 & 2 & $<.5$ & 3 & 1.4 & .3 & .4 & .20 & $<.01$ & .3 & .02 \\
\hline & * & 7 & $<1$ & 14 & 5 & 2 & $<.5$ & 3 & 2.7 & .4 & .6 & .20 & $<.01$ & .3 & .02 \\
\hline 3/HS-8 & $4.0-4.5$ & 11 & 40 & 36 & 10 & 5 & $<.5$ & 33 & 3.7 & 1.2 & .4 & 1.80 & .02 & 3.6 & .49 \\
\hline $4 / \mathrm{TP}-4$ & $2.0-4.0$ & 45 & 70 & 500 & 14 & 9 & .9 & 48 & 8.5 & 1.1 & .6 & 2.20 & .01 & 4.4 & .33 \\
\hline $4 / T P-6$ & 4.0 & 34 & 37 & 92 & 15 & 10 & $<.5$ & 32 & 5.1 & 1.9 & .4 & 1.60 & .08 & 2.9 & .28 \\
\hline
\end{tabular}

$1 /$ Collected on 0̀4-04-89.

2/Collected on 04-05-89.

3/Collected on 04-06-89.

4/Collected on 05-03-89.

\section{Ground Water}

Four of the six monitoring wells that were screened in the lower sand layer in the unconsolidated sediments have been dry since they were installed. Two wells, HS-1 and HS-9, consistently contained sufficient volumes of water to sample. A sample from well HS-9 was analyzed for volatile and semivolatile organic compounds; no compounds were detected in the sample. The results of the chemical analysis of the water sample collected from well HS-1 are presented in table 9.

Targeted volatile organic compounds were not detected in the ground-water sample collected from well HS-1. Of the targeted semivolatile organic compounds, five were identified at relatively low levels: pyrene $(2.8 \mu \mathrm{g} / \mathrm{L})$, phenol $(3.2 \mu \mathrm{g} / \mathrm{L})$, and three deriviatives of phthalatic acid $(2.0,3.2$, and 10.6 $\mu \mathrm{g} / \mathrm{L})$. 
Table 9.--Semivolatile organic-compound concentrations detected in ground water from well HS-1, April 21, 1989

\begin{tabular}{l|l} 
[ $[\mu \mathrm{g} / \mathrm{L}$, micrograms per liter $]$ \\
\hline Compound & $\begin{array}{c}\text { Concentration } \\
(\mu \mathrm{g} / \mathrm{L})\end{array}$ \\
\hline Pyrene & 2.8 \\
Phenol & 3.2 \\
Bis(2-ethylhexyl) & 10.6 \\
phthalate & 3.2 \\
Di-n-butylphthaiate & 2.0 \\
Diethylphthalate & \\
\hline
\end{tabular}

\section{Drainage Ditch Seep}

One potentiai pathway for the release of gas plant contaminants to the Flint River is by surface discharge of contaminated ground water at the seep in the drainage ditch (fig. 2). The resuits of the chemical anaiysis of a water sampie collected from this a seep for volatile organic compounds indicates moderate concentrations of napthalene, benzene, xylenes (totai), and ethylbenzene (table 10). Napthalene was detected in the highest concentration at $1,500 \mu \mathrm{g} / \mathrm{L}$.

Table 10.--Volatile organic-compound concentrations in seep, June 1, 1989

$[\mu \mathrm{g} / \mathrm{L}$, micrograms per liter; detection level is $3.0 \mu \mathrm{g} / \mathrm{L}]$

Compound

Concentration

$(\mu \mathrm{g} / \mathrm{L})$

Naphthaiene

Benzene

Xylenes (totai)

Ethylbenzene

1,2,4-Trimethylbenzene

1,3,5-Trimethylbenzene

Toluene

p-Isopropyltoluene

isopropylbenzene

Styrene
1,500

750

130

61

31

25

4.1 


\section{Streambed Sampling}

A reconnaissance of the Flint River adjacent to the study area was conducted to collect streambed sediments, and to search for visual evidence of hydrocarbon (tarry) material. More than $\mathbf{5 0}$ attempts were made to collect streambed sediments, upstream, adjacent to, and downstream from the study area, by using clamshell-type Ponar and Eckman dredges. The results of the survey indicate that the bed of the river is virtually sediment-free, probably as a result of scouring by relatively high-velocity flows. No evidence of tar deposits was detected during the sampling effort.

\section{SUMMARY}

Gas used for lighting and heating in much of the United States was produced from coal or oll, or a combination of both, at manufactured gas plants prior to the development of extensive networks of natural gas pipelines in the 1950's. The primary wastes and by-products resulting from the gas-manufacturing process included tar and oil residues and sludges, spent oxides, and ash materials. These wastes can consist of complex mixtures of hundreds of aromatic hydrocarbons, as well as cyanides and metals. Many constituents of the wastes are listed as carcinogens or priority pollutants, or both, by the Environmental Protection Agency (1989). By-products and wastes were commonly disposed of on site. In January 1989, an investigation was initiated by the U.S. Geological Survey in cooperation with the Albany Water, Gas, and Light Commission in the area of an abandoned manufactured gas plant In Albany, Ga., to assess the extent and movement of contaminants associated with past gas-plant operations in hydrogeologic environments similar to those in the area. Results from this study can be used to guide investigations and management decisions involving this and other abandoned manufactured gas plants located in similar hydrogeologic settings.

Geologic formations of interest to this investigation area in descending order, unconsolldated sediments consisting of sand and clay, the Ocala Limestone, and the Lisbon Formation. Surficial flll (manmade) overlies the sand and clay layers throughout the study area. There are two, seasonally-saturated, water-bearing units in the unconsolidated sediments: (1) an upper sand layer, generally less than $10 \mathrm{ft}$ in depth, which receives recharge from direct infiltration of rainfall through the fill material; and (2) a lower sand layer, which is in contact with the Ocala Limestone. The two sand layers are separated by a restricting clay layer that restricts vertical ground-water movement. Water in the lower sand layer responds to the changes in the stage of the Flint River. Water in the upper sand layer is perched on the clay layer. This upper clay layer is absent in the southeastern part of the area of the abandoned gas plant.

Organic compounds present in the unconsolidated sediments were found in four phases: (1) the hydrocarbon fluid phase; (2) the hydrocarbon solid phase; (3) the aqueous phase; and (4) the volatile (vapor) phase. The hydrocarbon fluid and solid phases generally were confined to areas near the former gas holding tanks. The volatlle and aqueous phases of contaminants also were prevalent in this area, and locally were present in other parts of the study area, although in relatively lower concentrations.

Substantial amounts of organic compounds were found in samples collected near the former gas holding tanks. A dense liquld sample of hydrocarbon waste collected near the site of former tank A (well B5) contained elevated levels of naphthalene $(18,000 \mu \mathrm{g} / \mathrm{L}$ volatile and $7,200 \mu \mathrm{g} / \mathrm{L}$ semivolatile), various alkylated benzenes (maximum concentratlons of $17,000 \mu \mathrm{g} / \mathrm{L}$ volatlle), and phenanthrene, $(5,300 \mu \mathrm{g} / \mathrm{L}$ semivolatile), as well as a number of other aromatic hydrocarbons and polyaromatic hydrocarbons. The most abundant volatile organic compounds (NOC's) detected in the sediment samples were naphthalene $(560,000 \mu \mathrm{g} / \mathrm{kg}$ ), various alkylated benzenes (maximum concentration of $73,000 \mu \mathrm{g} / \mathrm{kg}$ ), xylenes (maximum concentration of $40,000 \mu \mathrm{g} / \mathrm{kg})$, and toluene $(24,000 \mu \mathrm{g} / \mathrm{kg})$. 
Samples collected from the lower sand layer contained the same organic compounds as detected in the upper sand layer, but at much lower concentrations. A sediment sample collected just east of the former tank locations (well HS-2) contained relatively lower levels of all of the VOC's detected in the most contaminated sediment samples. A water sample from well HS-1 about 200 feet east of the former tank locations had no detectable levels of VOC's, and relatively low levels of pyrene $(2.8 \mu \mathrm{g} / \mathrm{L})$, phenol $(3.2$ $\mu \mathrm{g} / \mathrm{L})$, and three derivatives of phthalatic acid $(2.0,3.2$, and $10.6 \mu \mathrm{g} / \mathrm{L})$, which are semivolatile compounds.

VOC's also were detected in a sample collected from a seep in the drainage ditch near the southern boundary of the study area. Concentrations of naphthalene $(1,500 \mu \mathrm{g} / \mathrm{L})$, various benzene derivatives (maximum concentration of $750 \mu \mathrm{g} / \mathrm{L}$ ), and xylenes (total) $(290 \mu \mathrm{g} / \mathrm{L}$ ) also were detected.

High concentrations of metals were detected in samples collected from the unconsolidated sediments in the study area. The most notable concentrations were lead $(94 \mathrm{mg} / \mathrm{kg})$, zinc $(500 \mathrm{mg} / \mathrm{kg})$, and arsenic $(19 \mathrm{mg} / \mathrm{kg})$. These elevated concentrations of metals in the sediments generally correlated with high TOC concentrations.

Cyanide also was detected in samples from the unconsolidated sediments. Concentrations ranged from less than 200 to $1,600 \mu \mathrm{g} / \mathrm{kg}$ throughout the study area.

The results of this preliminary investigation indicate that the area of greatest hydrocarbon contamination in the unconsolidated sediments seems to be confined to the vicinity of the former gas holding tanks of the former gas plant. Naphthalene and various alkylated benzenes are the prevalent organic compounds present in the subsurface. In the area near the former tanks, the contamination extends at least to the top of the Ocala Limestone. Levels of contamination seem to decrease with increasing horizontal distance away from the former tank locations.

\section{REFERENCES}

Air Photography and Cartographic Service, Military Affairs Transportation Service, 1962, Aerial photography of Albany, Georgia: Flown by 1370th Photo Mapping Wing, Military Affairs Committee RC-130 Orientation Flight, Turner Air Force Base, Albany, Georgia, January 12, 1962.

Benson, R.C., Glaccum, R.A., and Noel, M.R., 1983, Geophysical techniques for sensing buried wastes and waste migration: Environmental Monitoring Systems Laboratory, Office of Research and Development, Las Vegas, Nevada, U.S. Environmental Protection Agency, 236 p.

Brown, E., Skougstad, M.W., and Fishman, M.J., 1970, Methods for collection and analyses of water samples for dissolved minerals and gases: U.S. Geological Survey Techniques-of-WaterResources Investigations, Book 5, Chapter A1, 160 p.

Carter, R.F. and Putnam, S.A., 1978, Low-flow frequency of Georgia Streams: U.S. Geological Survey Water-Resources Investigations Report 77-127, 104 p.

Edison Electric Institute, 1984, Handbook on manufactured gas plant sites: ERT Project number P-D215, prepared for: Utility Solid Waste Activities Group; Superfund Committee, Washington, D.C.

Gas Research Institute, 1987, Management of manufactured gas plant sites: GRI-87/0260.1-4, October, 1987, v. I-IV, Chicago, Illinois.

Gilkeson, R.H., Heigold, P.C., and Layman, D.E., 1986, Practical application of theoretical models to magnetometer surveys on hazardous waste disposal sites - a case history: Ground Water Monitoring Review, v. III, no. 2, p. 54-61. 


\section{REFERENCES-Continued}

Hayes, L.R., Maslia, M.L., and Meeks, W.C., 1983, Hydrology and model evaluation of the principal artesian aquifer, Dougherty Plain, southwest Georgia: Georgia Geologic Survey Bulletin 97, 93 p.

Hicks, D.W., Gill, H.E., and Longsworth, S.A., 1987, Hydrogeology, chemical quality, and availability of ground water in the Upper Floridan aquifer: U.S. Geological Survey Water-Resources Investigations Report 87-4145, 52 p.

Hult, M.F. and Schoenberg, M.E., 1984, Preliminary evaluation of groundwater contamination by coal-tar derivatives, St. Louis Park area, Minnesota: U.S.Geological Survey Water-Supply Paper 2211, $53 \mathrm{p}$.

Keller, G.V., and Frischknecht, F.C., 1982, Electrical methods in geophysical prospecting: Pergamon Press, Inc., Oxford, Great Britain, 523 p.

Lacombe, P., Sargent, B.P., Harte, P.T., and Vowinkel, E.F., 1986, Determination of geohydrologic framework and extent of ground-water contamination at Picatinny Arsenal, New Jersey: U.S. Geological Survey Water-Resources Investigations Report 86-4051, 31 p.

MCNeill, J.D., 1980, Electrical conductivity of soils and rocks: Geonics Limited, technical note TN-5, October, Ontario, Canada, 22 p.

--- 1983, EM34-3 survey interpretation techniques: Geonics Limited, technical note TN-6, Ontario, Canada, $15 \mathrm{p}$.

Norris Wellge and Co., 1885, A view of the city of Albany, Georgia, 1885: map, 107 Wells St., Milwaukee, Wisconsin.

Pereira, W.E. and Rostad, C.E., 1986, Geochemical investigations of organic contaminants in the subsurface at Creosote Works, Pensacola, Florida: in Movement and fate of Creosote waste in ground water, Pensacola, Florida, Chapter E: U.S. Geological Survey Water-Supply Paper 2285, p. 33-40.

Perkins, H.F., 1987, Characterization data for selected Georgia soil: University of Georgia, College of Agriculture, Georgia Experiment Station, Special Publication No. 43, 545 p.

Sanborn Map Company, 1911, Insurance maps of Albany, Dougherty County, Georgia: New York, December, 1911, p. 21.

---- 1920, Insurance maps of Albany, Dougherty County, Georgia, including Putney: New York, April, 1920, p. 28.

---- 1930, Insurance maps of Albany, Dougherty County, Georgia, including Putney and Radium Springs: New York, February, 1930, p. 19 


\section{REFERENCES-Continued}

Saunders, W.R., and Cox, S.A., 1987, Use of electromagnetic induction technique in subsurface hydrocarbon investigations: in Proceedings of the First National Outdoor Action Conference on Aquifer Restoration, Ground Water Monitoring and Geophysical Methods, May 18-21, Las Vegas, Nevada, p. 585-599.

Spruill, T.B., 1988, Use of total organic carbon as an indicator of contamination from an oil refinery, Southcentral Kansas: Ground Water Monitoring Review, v. 8, no. 3, p. 76-82.

Stokes, W.R., III, MacFarlane, R.D., and Buell, G.R., 1989, Water resources data, Georgia, water year 1988: U.S. Geological Survey Water-Data Report GA-88-1, 438 p.

The Albany Herald, 1925a, Flint River here reaches highest stage ever known: Albany, Ga., in The Albany Herald Newspaper, January 19, 1925, v. 34, no. 73, p. 1.

--- 1925b, First photos of flooded areas around Albany: Albany, Ga., in The Albany Herald Newspaper, January 26,1925, v. 34 , no. 80 , p. 3.

University of Georgia, 1989, Population of Georgia, by component parts of metropolitan statistical areas, 1980 and 1986, in Georgia Statistical Abstract, 1988-89, L.M. Akioka, ed:: Division of Research, College of Business Administration, Athens, Ga., p. 3.

U.S. Army Corps of Engineers, 1985, Interim drought management plan for the ApalachicolaChattahoochee-Flint River Basin: Mobile, Ala., April, 1989, 279 p.

U.S. Environmental Protection Agency, 1986, Water quality criteria summary: in Quality Criteria for Water, 1986, Office of Water Regulation and Standards, EPA 440/5-86-001, Washington, D.C.

1988, U.S. production of manufactured gases: assessment of past disposal practices: U.S. Department of Commerce, National Technical Information Service, PB 88-165790, February, 1988, $388 \mathrm{p}$.

---- 1989, Protection of environment: in Code of Federal Regulations 40, part 423, Appendix A, p. 736-737.

Wood, W.W., 1976, Guidelines for collection and field analysis of ground-water samples for selected unstable constituents: U.S. Geological Survey Techniques of Water-Resources Investigations, Book 1, Chapter D2, 24 p. 


\section{SUPPLEMENTAL DATA}

\section{Geologic Logs}

[ft, feet; ppm, parts per million; HNU, HNU Systems, Inc.1/; OVA, Century Organic Vapor Analyzer]

$\begin{array}{ccc}\begin{array}{c}\text { Boring } \\ \text { no. }\end{array} & \text { Depth } & \text { Description }\end{array}$

B-1

0.0-1.0

1.0-2.0

2.0-5.5

5.5-7.0

B-2

0.0-1.0

1.0-2.0

2.0-5.0

B-3

$0.0-1.0$

1.0-2.0

2.0-7.0

B-4

0.0-1.0

$1.0-2.0$

2.0-8.0

B-5 $\quad 0.0-4.0$

4.0-8.0

8.0-10.0

B-6

$0.0-4.0$

$4.0-8.0$

8.0-8.5

B-7

0-3.5

$3.5-10.0$

B-8 $\quad 0.0-4.0$

4.0-10.0

B-9 $\quad 0.0-2.0$ fill, light yellowish-brown, sandy.

fill, black (hydrocarbon-stained), clayey.

sand, dark brown, silty.

clay, reddish-brown, sandy with some pebbles; very tight.

fill, light yellowish-brown, sandy.

fill, black, blocky, cinder material (?); clay percentage is less than black material in B-1 (1.0-2.0 ft). sand.

fill, sandy.

fill, biack (hydrocarbon-stained), blocky, dry; 0.5 - to 1 -in. diameter pieces that increasing in size with depth; detectable hydrocarbon odor, $\mathrm{HNU}$ readings of 30 to $50 \mathrm{ppm}$. sand, silty.

fill, loamy sand.

fill, black granular, somewhat blocky; smaller diameter material than in B-3 $(1.0-2.0)$. sand, loamy, granular.

fill, clayey; pieces of tar within matrix; tar is somewhat weathered.

sand, yellowish-brown, loamy.

sand, black (hydrocarbon-stained), loamy; stained and saturated with free-flowing tar or oil; detectable hydrocarbon odor, $\mathrm{HNU}$ reading of $70 \mathrm{ppm}$.

clay, dark reddish-brown, stained.

sand, clayey; saturated with oil; detectable hydrocarbon odor.

clay, dark yellowish-brown, sandy with some pebbles; contains cracks.

sand.

clay, mottled yellowish-brown and bluish-gray; damp, tight, plastic; stained, detectable hydrocarbon odor.

clay, dark reddish-brown, sandy.

sand, reddish-brown, coarse, clayey.

fill, sand, pieces of brick and concrete; auger unable to penetrate below $2.0 \mathrm{ft}$.

$1 /$ The use of brand names in this report is for identification purposes only, and does not constitute endorsement by the U.S. Geological Survey. 


\section{SUPPLEMENTAL DATA}

\section{Geologic Logs}

[ft, feet; ppm, parts per million; HNU, HNU Systems, Inc.1/; OVA, Century Organic Vapor Analyzer]

\begin{tabular}{ccc|c}
\hline $\begin{array}{c}\text { Boring } \\
\text { no. }\end{array}$ & $\begin{array}{c}\text { Depth } \\
(\mathrm{ft})\end{array}$ & Description & \\
\hline
\end{tabular}

B-10 $\quad 0.0-1.5$

fill, dark brown, sand, pieces of brick and concrete; auger unable to penetrate below $1.5 \mathrm{ft}$.

B-11 $\quad 0.0-1.0 \quad$ fill, stained, sandy.

1.0-3.0 fill, yellowish-brown, sandy.

3.0-4.5 fill, black, blocky and ashy material in sand; auger unable to penetrate below $4.5 \mathrm{ft}$.

B-12 $\quad 0.0-4.0$

fill, yellowish-brown, sandy; auger unable to penetrate below $4 \mathrm{ft}$.

B-13 0.0-4.0 fill, yellowish-brown sandy.

4.0-5.0 fill, stained, sandy; auger unable to penetrate below $5 \mathrm{ft}$.

B-14 $\quad 0.0-4.0$

fill, yellowish-brown, sandy; auger unable to penetrate below $4 \mathrm{ft}$.

B-15 $\quad 0.0-2.0 \quad$ fill, clayey, sandy.

2.0-5.5 sand, dark brown, silty with some pebbles; loose, former upper soil or land surface (A-horizon); clay percentage is less than above fill $(0.0-2.0 \mathrm{ft})$.

5.5-6.5 ashy material, black; very loose; increase in clay percentage from above $(2.0-5.5 \mathrm{ft})$; some hydrocarbon sheen present.

6.5-9.0 clay, reddish-brown; vertical and horizontal cracks; some mottling along cracks.

B-16 $\quad 0.0-3.5$

clay, reddish-brown, sandy; some evidence of staining at $0.5 \mathrm{ft}$; 1-in. diameter glassy cinders in matrix; very thick hydrocarbon oil in clay at $3.5 \mathrm{ft}$; HNU reading of $8.5 \mathrm{ppm}$; auger unable to penetrate below $3.5 \mathrm{ft}$.

B-17 $\quad 0.0-2.5$

clay, light black, sandy; cinder layer within matrix; auger unable to penetrate deeper than $2.5 \mathrm{ft}$.

B-18 $\quad 0.0-10.0$

fill, reddish-brown, sandy; coarse sand; pieces of tar and cinders in matrix at $3.5 \mathrm{ft}$.

10.0-10.5 clay, plastic; very dry; some evidence of staining.

B-19 $\quad 0.0-2.0$

fill, black, sandy; medium sand.

clay, light brown, gravelly; gravel consists of cinder fragments; perched ground water at $4.0 \mathrm{ft}$. 


\section{SUPPLEMENTAL DATA}

\section{Geologic Logs}

[ft, feet; ppm, parts per million; HNU, HNU Systems, Inc.1/; OVA, Century Organic Vapor Analyzer]

$\begin{array}{ccc}\begin{array}{c}\text { Boring } \\ \text { no. }\end{array} & \begin{array}{c}\text { Depth } \\ (\mathrm{ft})\end{array} & \text { Description }\end{array}$

B-20

0.0-2.5

2.5-7.0

7.0-9.0

8.5-9.0

B-21

0.0-5.0

5.0-5.5

5.5-7.5

HS-1

0.0-2.5

2.5-7.0

7.0-10.0

10.0-11.0

$11.0-12.5$

12.5-22.0

22.0-25.0

25.0-27.0

27.0-27.5

27.5-28.0

28.0-28.5

28.5-30.5

HS-2

22.5-23.0

fill, brown, clayey sand; damp; slight staining. clay, brown; hydrocarbon stained; detectable hydrocarbon odor. sand, black; some clay pods; hydrocarbon staining. clay, brown; no evidence of staining.

fill, brown clayey.

fill, reddish-brown, sandy; low percentage of clay (clean).

clay; highly contaminated at $5.5 \mathrm{ft}$; strong hydrocarbon odor; slight staining at $7.0 \mathrm{ft}$.

fill, dark reddish-brown, silty sand; gravelly; gravel is black cinder chips.

sand, dark reddish-brown, clayey; friable; former upper soil or land surface (A-horizon); gravelly with wood chips and twigs; less consolidated than above fill $(0.0-2.5 \mathrm{ft})$.

clay, dark reddish-brown, sandy; partially saturated with water; black staining along vertical cracks; very tight.

sand, dark reddish-brown, clayey.

clay, dark reddish-brown, sandy.

sand, reddish-brown; white, finer sand at $18-19.5 \mathrm{ft}$; very clean.

clay, bluish-gray, sandy; damp; sand percentage increases with depth.

sand, gray; reddish-brown at $26 \mathrm{ft}$; saturated with water.

clay, reddish-brown, sandy, graveily; limestone fragments and gravel near bottom of sampie.

sand, gray.

clay, mottled, bluish-gray and reddish-brown, silty, gravelly; some cracks present; gravel is limestone.

sand, gray; limestone contact (auger refusal) at about $30.5 \mathrm{ft}$.

fill, dark reddish-brown, clayey sandy with some gravel; stained black with pieces of slag.

fill, dark brown, silty, sandy; detectable hydrocarbon odor; OVA reading of $300 \mathrm{ppm}$.

clay, reddish-brown, sand; evidence of both vertical and horizontal migration of black material along cracks; two horizons of hydrocarbon stains within the clay--1 to 2 in. thick.

silt, dark brown, gravelly, clayey with some gravel; former upper soil or land surface (A-horizon); chert/flint gravel; pieces of brick present. sand, dark-brown to black, silty.

clay, reddish-brown, sandy; sand percentage increases at $14.0 \mathrm{ft}$.

sand, dark yellowish-brown, coarse very clean.

sand, dark gray, coarse; damp; stained; detectable hydrocarbon odor; OVA greater than $1,000 \mathrm{ppm}$.

clay, mottled, reddish-brown and bluish-gray, sandy with some gravel; sand is coarse; gravel is limestone; limestone contact (auger refusal) at about $23 \mathrm{ft}$. 


\section{SUPPLEMENTAL DATA}

\section{Geologic Logs}

[ft, feet; ppm, parts per million; HNU, HNU Systems, Inc. 1/; OVA, Century Organic Vapor Analyzer]

\begin{tabular}{cc|c|c}
$\begin{array}{c}\text { Boring } \\
\text { no. }\end{array}$ & $\begin{array}{c}\text { Depth } \\
\text { (ft) }\end{array}$ & Description & \\
\hline
\end{tabular}
HS-3 $\quad 0.0-5.0 \quad$ fill, clayey sand; pieces of asphalt, concrete, and brick rubble in matrix.
5.0-8.0 sand, black (hydrocarbon-stained); damp; tar- or oil-stained, hydrocarbon order detectable at $6.5 \mathrm{ft}$; similar in texture and color to stained sample in B-5 (8.0-10.0 ft); tar and oil not as "free-flowing" or liquid as in B-5.

$\begin{array}{ll}\text { HS-4 } & 0.0-5.0 \\ & 5.0-10.0 \\ & 10.0-11.5 \\ & 11.5-12.0 \\ & 12.0-14.5\end{array}$
fill, reddish-brown, clayey, silty sand; pieces of weathered asphalt in matrix.
sand, reddish-brown, clayey with some gravel.
clay, reddish-brown, sandy with white gravel, very tight.
clay, dark reddish-brown, gravely, very gravelly; gravel is white limestone.
clay, bluish-gray, gravelly; gravel is limestone; limestone contact at about $14.5 \mathrm{ft}$.

HS-5 $\quad 0.0-3.0$

fill, dark reddish-brown, silty sandy with some clay lensesand pebbles; chips of bituminous coal present; auger unable to penetrate below $3.0 \mathrm{ft}$.
HS-6 $\quad \begin{array}{r}0.0-1.0 \\ 1.0-2.5\end{array}$
fill, dark yellowish-brown, sandy.
sand, black, clayey with some gravel; damp; bituminous coal ashes present in matrix, no detectable hydrocarbon odor.
2.5-5.0
$5.0-7.5$
fill, dark yellowish-brown, sandy.
fill, dark yellowish-brown, loamy coarse sand; auger unable to penetrate below $7.5 \mathrm{ft}$.
HS-7 $\quad 0.0-6.0$
HS-8 $\quad 0.0-2.5$
2.5-3.5 fill, dark reddish-brown, coarse sand; clean; auger unable to penetrate
below $6.0 \mathrm{ft}$.
fill, reddish-brown, clayey sand with some gravel.
fill, black (hydrocarbon-stained), loamy sand and gravel; gravel is tar chips; strong hydrocarbon odor, OVA reading greater than 1,000 ppm.
3.5-5.0
fill, brown to black (stained), clayey sand; pieces of brick in matrix; strong hydrocarbon odor.
5.0-10.0 clay, black sandy; damp; similar to black material in B-5 (8.0-10.0 ft); strong hydrocarbon odor, OVA reading greater than 1,000 ppm.
10.0-11.5 silt, black, clayey with a few pebbles; hydrocarbon sheen present; organic matter--leaves, twigs--present in matrix; strong hydrocarbon odor.
11.5-14.0 clay, mottled, black, reddish-brown, and bluish-gray sandy; cracks present; hydrocarbon sheen visible in cross-section; strong hydrocarbon odor; limestone contact at about $14.0 \mathrm{ft}$. 


\section{SUPPLEMENTAL DATA}

\section{Geologic Logs}

[ft, feet; ppm, parts per million; HNU, HNU Systems, Inc.1/; OVA, Century Organic Vapor Analyzer]

$\begin{array}{ccc}\begin{array}{c}\text { Boring } \\ \text { no. }\end{array} & \text { Depth } & \text { Description } \\ & (\mathrm{ft}) & \end{array}$

HS-9 $\quad 0.0-1.5$

$1.5-3.5$

$3.5-5.0$

$5.0-6.5$

6.5-12.5

12.5-20.0

20.0-24.5

24.5-25.0

25.0-27.5

HS-10 $\quad 0.0-4.5$

$4.5-6.0$

6.0-10.5

10.5-12.5

12.5-18.5

$18.5-20.0$

20.0-21.0

21.0-22.5

22.5-24.0

HS-11 $\quad 0.0-2.5$

2.5-5.5

$5.5-6.0$

$6.0-8.5$

8.5-11.5 fill, reddish-brown to dark brown, sandy; gravelly; stained.

fill, reddish-brown, clayey sand with some gravel; mottled reddish-brown and dark reddish-brown at about $3.5 \mathrm{ft}$; stained; wood fragments and pieces of tar present in matrix.

silt, dark brown, sandy; sand is fine-grained; granular; very friable; former upper soil or land surface (A-horizon); organic matter--twigs-present in matrix.

silt, dark yellowish-brown, sandy; sand is fine-grained sand; friable; low percentage of clay; gravel and stained material at bottom of sample.

sand, reddish-brown, sand is medium to coarse; fairly clean; slightly silty; damp.

sand, light yellowish-brown; sand is coarse; very clean; damp.

sand, reddish-brown; sand is medium to coarse; darker and coarser at $22.5 \mathrm{ft}$; water table at about $24.2 \mathrm{ft}$.

sand, gray, silty; clay is present in reddish-brown sand as a lense.

sand, mottled, reddish-brown and light bluish-gray clayey; sand is medium to fine sand (bottom of sample); wet; limestone contact at about $27.5 \mathrm{ft}$.

fill, dark brown, clayey and silty; abundant pieces of wood.

fill, black (stained) sandy; dry, ashy material (weathered tar?) is present in matrix; detectable hydrocarbon odor.

clay, reddish-brown sandy; plastic; sand percentage increases with depth; horizontal cracks about $0.5-1.5$ in. apart; evidence of staining near top of sample interval.

sand, reddish-brown, very clayey; sand is coarse; no evidence of staining. sand, dark reddish-brown and mottled, reddish-brown and bluish-gray loamy; sand is coarse; wet.

silt, mottled bluish-gray and reddish-brown, clayey; damp; limestone fragments at bottom of sample interval.

clay, white-to-gray, sandy; iron-oxide stains; wet.

clay, reddish-brown, sandy; slightly mottled bluish-gray and reddishbrown; low sand percentage; very tight.

clay, white, sandy, gravelly; gravel is limestone; contact with limestone at about $24.0 \mathrm{ft}$.

fill, reddish-brown, clayey sand; gravelly; stained black; organic matter present; gravel is pieces of fire brick.

fill, black, clayey and silty, gravelly; contains ash, slag, and pieces of brick; detectable hydrocarbon odor.

gravel, white; noncalcareous.

silt, brown to dark gray (stained); sandy; not as black as above horizon $(2.0-5.5 \mathrm{ft})$.

clay, dark gray (stained); silty and sandy; horizontal (cracks) at $10.0 \mathrm{ft}$; stains disperse at $11 \mathrm{ft}$. 


\section{SUPPLEMENTAL DATA}

\section{Geologic Logs}

[ft, feet; ppm, parts per million; HNU, HNU Systems, Inc. 1/; OVA, Century Organic Vapor Analyzer]

\begin{tabular}{ccc}
$\begin{array}{c}\text { Boring } \\
\text { no. }\end{array}$ & $\begin{array}{c}\text { Depth } \\
(\mathrm{ft})\end{array}$ & Description \\
\hline
\end{tabular}

HS-11--Continued

11.5-15.0 clay, dark yellowish-brown, very sandy; sand is coarse; fairly tight; iron-

15.0-16.5 sand, yellowish-brown, clayey; sand is coarse; iron-oxide staining; no evidence of hydrocarbon staining.

16.5-17.5 clay, yellowish-brown, sandy; very tight.

17.5-22.5 sand, yellowish-brown, clayey; sand is very coarse; mottled gray and yellowish-brown at about $22 \mathrm{ft}$; clay percentage decreases at $18.5 \mathrm{ft}$.

22.5-23.5 clay, yellowish-brown and greenish-brown, sandy, gravelly; horizontal cracks; fossils imbeded in clay; limestone contact at about $23.5 \mathrm{ft}$.

HS-12 $\quad 0.0-5.0$

5.0-9.5 sand, black (hydrocarbon-stained), silty, gravelly; sand is medium; pieces

fill, dark reddish-brown, sandy, silty; sand is medium; pieces of fire brick present; iron-oxide staining; clay increases near bottom of sample--very tight.

sand, black (hydrocarbon-stained), silty, gravelly; sand is medium; pieces
of slag in matrix; saturated with oil; black, sandy clay lenses from 6.0$6.5 \mathrm{ft}$; moderate hydrocarbon odor.

9.5-15.0 clay, reddish-brown, sandy; sandy with some gravel; fractured in vicinity of gravel; most of the staining ends at $9.5 \mathrm{ft}$; mottled reddish-brown and bluish-gray at $10.0 \mathrm{ft}$; sand percentage increases at $10.0 \mathrm{ft}$.

15.0-16.0 sand, mottled, bluish-gray and light reddish-brown; clayey; sand is coarse; saturated with water.

16.0-17.0 clay, bluish-gray, sandy; tight; wet; limestone contact at about $17.0 \mathrm{ft}$. 